



\title{
STRUCTURAL REFORMS, PRODUCTIVITY AND TECHNOLOGICAL CHANGE IN LATIN AMERICA
}

\author{
Jorge M. Katz
}

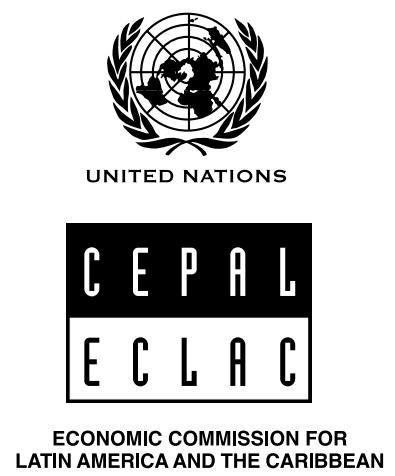

Santiago, Chile, 2001 


\section{Libros de la CEPAL}

This book has been prepared by Jorge Katz, Director of the Division of Production, Productivity and Management at ECLAC Santiago, and published by the Economic Commission for Latin America and the Caribbean (ECLAC).

This book has been published as part of a project funded by the Netherlands Ministry for Development Cooperation and with contributions from the International Development Research Centre of Canada (IDRC).

Cover illustration and design by Andrés Hannach.

Composition by Gilabert\&Domeyko Ltda.

United Nations Publication

LC/G.2129-P

ISBN: 92-1-121295-2

Copyright $@$ C United Nations, May 2001. All rights reserved

Sales No. E.01.II.G.22

Printed in Chile

Applications for the right to reproduce this work are welcomed and should be sent to the Secretary of the Publications Board, United Nations Headquarters, New York, N.Y. 10017, U.S.A. Member States and their governmental institutions may reproduce this work without prior authorization, but are requested to mention the source and inform the United Nations of such reproduction. 
- The fact that we can predict eclipses does not mean that we can predict revolutions.

- Five overlapping sub-systems -science, technology, economy, politics and general culture-influence the process of economic growth. Although each of the five has its own distinctive features and relative autonomy, it is their interdependence and interaction which provides major insights into the processes of "forging ahead", "catching up" and "falling behind" in economic growth.

Christopher Freeman, History, Co-evolution and Economic Growth, University of Sussex, Science Policy Research Unit 



\section{TABLE OF CONTENTS}

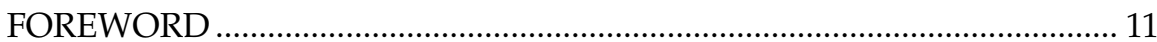

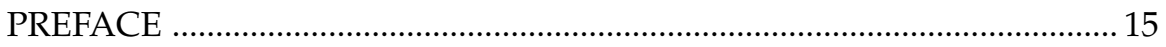

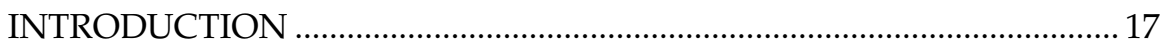

PART ONE. THEORETICAL FRAMEWORK ………………….................... 27

Chapter I.

ECONOMIC, TECHNOLOGICAL AND INSTITUTIONAL

FORCES CONDITIONING INVESTMENT AND INNOVATION ..............29

A. The Three Phases of a Macroeconomic Stabilization and Structural Reform Policy Programme ..................................... 33

B. Changes at the Meso- and Microeconomic Levels during the Different Phases of the Stabilization and Structural Reform Programme ........................................................................... 36

C. Failure of the Macroeconomic Stabilization Efforts ........................ 40

D. Coevolution of Economic, Technological and Institutional Forces During the Structural Adjustment Process 42 
Chapter II.

THE DYNAMICS OF THE INDUSTRIAL

RESTRUCTURING PROCESS

A. The Selection Process among Firms in a Given Industry ........... 45

B. Changes in the Relative Share of Industries During the Structural Adjustment Process

C. The Destruction of Human Capital During the Structural Adjustment Process

PART TWO. STRUCTURAL REFORMS AND ECONOMIC PERFORMANCE: THE EVOLUTION OF LABOUR PRODUCTIVITY ..... 55

Chapter III.

TECHNOLOGICAL CHANGE AND LABOUR PRODUCTIVITY GROWTH IN LATIN AMERICAN MANUFACTURING INDUSTRIES ... 57

A. Labour Productivity as a Proxy for Technical Change ............... 57

B. Labour Productivity in the Latin American Manufacturing Sector Before and After Recent Structural Reforms .................... 59

C. Labour Productivity Growth at the Individual Industry Level .. 62

D. The Acceleration of Labour Productivity Growth in the 1990s and the Impact of the Structural Reforms 64

E. Why Some Industries Catch Up While Others Fall Behind in the Process of Economic Growth

F. Sectoral Competitive and Technological Regimes ..................... 70

Chapter IV.

TECHNOLOGICAL CHANGE AND LABOUR

PRODUCTIVITY GROWTH IN NON-MANUFACTURING

SECTORS: TELECOMMUNICATIONS SERVICES AND MINING ...........73

A. The Telecommunications Sector .................................................... 73

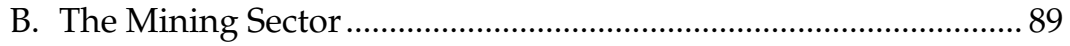

Chapter V.

THE IMPACT OF STRUCTURAL REFORMS ON EMPLOYMENT, THE TRADE BALANCE IN MANUFACTURING AND THE RELATIVE PRODUCTIVITY GAP BETWEEN SMALL AND LARGE FIRMS

A. Employment ......................................................................... 97

B. The Relative Labour Productivity Gap Between

Small and Large Firms

C. Towards a Chronic Trade Balance Deficit in Manufacturing? .. 106 
PART THREE. TOWARDS A NEW POLICY AGENDA

Chapter VI.

THE INSTITUTIONAL AND TECHNOLOGICAL ENVIRONMENT FOR THE CURRENT DEBATE ON A NEW POLICY AGENDA

A. The New International Trade Disciplines ……………………..... 114

B. The Fragility of Domestic Innovation ........................................... 116

Chapter VII.

TOWARDS A NEW POLICY AGENDA

A. Neoclassical and Evolutionary Perspectives on the Appropriate Policy Agenda

B. A New Agenda Addressing Issues of Production Efficiency and Equity

BIBLIOGRAPHY 



\section{FOREWORD}

At the start of the new decade, the debate on economic policy centres on the consequence of the reforms implemented in Latin America and the Caribbean in the last two decades. Trade and financial liberalization and the privatization of production activities have radically altered the rules of the game governing labour and business. The macroeconomic policy changes that accompanied or preceded the reforms sometimes strengthened the latter's specific objectives, especially the growth of exports, but on other occasions they had the opposite effect. That combination of factors prompted the emergence of new market structures and transformations in microeconomic behaviour.

Assessing the effects of the reforms on economic growth, employment and income distribution is of more than academic interest. Governments, political parties and social actors require a thorough evaluation of the results, so as to devise or propose policies that complement the reforms or counter their unwanted consequences. The Economic Commission for Latin America and the Caribbean (ECLAC) actively participates in this process.

This book is part of a project carried out by ECLAC, in conjunction with researchers from nine countries, to study the impact of the reforms. Directed by Dr. Barbara Stallings, the project has produced 14 books and 70 working papers. The summary appears in the first volume, entitled Growth, Employment and Equity: The Impact of the Economic Reforms in Latin America and the Caribbean. It is complemented by four issue-specific volumes analysing investment, technological change, employment and equity. Additionally, another nine country volumes examine the particular characteristics of the reforms in Argentina, Bolivia, Brazil, Chile, Colombia, Costa Rica, Jamaica, Mexico and Peru. The working papers are available at ECLAC's web site (www.cepal.cl). 
One feature of the project that distinguishes it from other comparative studies of economic reform is that it specifically addresses the interaction between macroeconomic and microeconomic processes. To understand the impact of the reforms more fully, it is necessary to disaggregate the regional level and to study the differences between countries and in the microeconomic behaviour of firms according to sector, size and ownership. The globalization of the economy and government policies such as structural reform affect different countries and groups of firms in different ways. Some have been able to exploit the new opportunities, while the situation of others has deteriorated. The outcome of such developments gives rise to aggregate trends that others have observed and measured, but to design economic policy measures and improve future performance, it is essential to know what underlies those aggregates.

In this book, Jorge Katz, Director of ECLAC's Division of Production, Productivity and Management, seeks to examine the impact of the structural reforms on labour productivity growth; the relative technological gap with the international productivity frontier; differences in technological behaviour among different groups of firms, such as subsidiaries of transnational firms, large national conglomerates and family-owned small and medium-sized enterprises; the creation and destruction of jobs; and the trade balance in manufacturing goods of the different countries of the region.

The study examines changes over time in Latin American countries' pattern of production specialization and participation in world trade of manufactured goods. It also seeks to determine which productive sectors have been the winners and losers following the structural transformation mentioned above, and what has happened to various types of firms during the adjustment to the new rules of the game. Finally, the book assesses the impact of structural transformation on employment and the foreign trade balance in manufacturing.

The findings show that two main models of production specialization have been consolidating in Latin America. On the one hand is the model unfolding in several South American countries -Argentina, Brazil, Chile and Uruguay- where relative share has been gained by natural resource-based industries producing industrial commodities such as iron and steel, pulp and paper, vegetable oil, fishmeal and aluminium. On the other hand, Mexico and several of the smaller countries of Central America have specialized in the production of assembly industries (maquilas) producing computer equipment, televisions, video recorders and clothing, largely for the United States market. In both cases there has also been an increase in the relative weight of non-tradable industries producing goods and services -such as, telecommunications, energy and transport- as well as in the automotive industry, which has received preferential treatment in all countries.

By contrast, engineering and labour-intensive industries have lost relative participation in gross domestic product (GDP). These include sectors which 
use unskilled labour rather intensively, for the production of consumer goods such as footwear and leather goods, furniture and textiles, and engineeringintensive industries producing capital goods, agricultural equipment or pharmaceutical raw materials. Among the "winning" sectors we find those in which local subsidiaries of transnational firms and large domestic conglomerates figure more prominently. In contrast, industries in which family-owned businesses tend to be the major actors have clearly lost ground throughout the region.

In sum, this study describes an episode of major transformations in the region's production structure, the most prominent consequence of which has been a sharp increase in each economy's degree of structural heterogeneity.

ECLAC could not have carried out a project of this scale without the cooperation of many individuals and institutions. We wish to thank the researchers that participated in each of the nine countries, as well as the coordinators of the thematic and national volumes. We are also indebted to the members of the project's External Advisory Committee: Nancy Birdsall, Director of Economic Programs at the Carnegie Endowment for International Peace; René Cortázar, Executive Director of Chilean National Television; Norman Hicks, senior economist at the World Bank; Juan Antonio Morales, President of the Central Bank of Bolivia; Pitou van Dijck, Professor of Economics at the University of Amsterdam; and Dorothea Werneck, Executive Director of the Brazilian Agency for Export Promotion.

External financing came from a number of international donors. First, we wish to recognize the central role of the Netherlands Ministry for Development Cooperation, which provided the project's basic donation. The International Development Research Centre of Canada (IDRC) also made a substantial contribution that allowed us to expand the scope of the project significantly. These two sources were supplemented with funds from the Ford Foundation and the Swedish International Development Agency. We offer our deepest thanks to all the donors, without whose support this project would not have been possible. 



\section{PREFACE}

More than two decades have passed since the region's first attempts to move towards a development strategy that was more open to foreign competition and more deregulated, in which the State had a smaller role in production activities. Those earliest efforts were made at the start of the 1970s by Chile and were later followed by similar initiatives in Mexico, Argentina, Colombia, Costa Rica and Brazil in the late 1980s and early 1990s. The change in development paradigm, which entailed the abandonment of the inwardoriented, state-led model of the postwar period, brought about great macro-, meso- and microeconomic changes. The production structure and the institutional and regulatory regime of the countries of the region underwent significant change as part of a profound, long-term structural transformation that is far from finished.

The combination of pro-competitive structural reforms, the historical features of each national economy and the impact of the world economy's increasing financial turbulence and volatility triggered a Schumpeterian episode of "creative destruction" through which a new economic, institutional and technological regime is gradually emerging. The micro- and mesoeconomic features of this regime have scarcely been researched so far.

This book presents the research findings of one of the five modules of a project entitled "Growth, employment and equity: Latin America and the Caribbean in the 1990s", which was conducted jointly by the Economic Development Division and the Division of Production, Productivity and Management at ECLAC's headquarters in Santiago, Chile. The study was carried out in close collaboration with various research centres and independent professionals from Argentina, Brazil, Chile, Colombia, Costa Rica and Mexico. 
Many people provided intellectual and analytical support during the three years covered by the research and writing of this book. At ECLAC's headquarters in Santiago, Chile, special mention should be made of the colleagues who were responsible for the other modules of the programme: Ricardo Bielschowsky, Graciela Moguillansky, Samuel Morley, Wilson Peres, Barbara Stallings and Jürgen Weller. Thanks are also due to Oscar Altimir, Martine Dirven, Ricardo Ffrench-Davis, José Antonio Ocampo, Juan Carlos Ramírez, Joseph Ramos and Giovani Stumpo for their contributions at various stages.

The research was conducted in direct collaboration with Roberto Bisang and Beny Kosacoff in Argentina; João Ferraz and Paulo Tigre in Brazil; José Miguel Benavente and Gustavo Crespi in Chile; Ricardo Chica in Colombia; Gustavo Barbosa and Rudolfo Buitelaar in Costa Rica; and Mario Capdeville, Mónica Casalett and Mario Címoli in Mexico. They all deserve my deepest thanks, though I obviously retain total responsibility for what is said throughout the book. Thanks also go to Paula Warnken and Isabel Massad for their efficient secretarial support, and to Ximena Sánchez and María Eugenia Johnson for their help in getting the manuscript into shape.

The book was originally published in Spanish under the title "Reformas Estructurales, Productividad y Conducta Tecnológica en América Latina", and it was translated into English by Andrew Crawley. I made considerable revisions in the translation, but the general arguments and conclusions nonetheless remain the same. Jennifer Hoover and Barbara Stallings are to be thanked for their editorial help in making these changes. 


\section{INTRODUCTION}

More than two decades have already elapsed since the first attempts were made in Latin America to move towards a development strategy that was more open to external competition and more deregulated, with less participation of the State as a producer of goods and services. Efforts in this direction began in Chile in the early 1970s and Argentina later in the same decade; Mexico and Costa Rica followed suit in the 1980s. Brazil appears as a late reformer, initiating market-oriented reforms only in the early 1990s. Such a paradigmatic change prompted enormous macro-, meso- and microeconomic changes. The production structure and the institutional and regulatory environment of the Latin American countries is currently in the middle of a deep, long-term structural transformation.

The transition to a new model of production organization and a new regulatory regime is far from being concluded. Even Chile, which is often cited in the international press as a country that has been able to return to a stable, long-term equilibrium growth path after the crisis of the 1970s, is far from having developed a well-behaved microeconomic scenario. Large interindustry and inter-regional differences in productivity can still be found in Chile today, suggesting that the transition towards a mature production structure has yet to be completed.

An analysis of the impact of recent structural reforms on the Latin American countries must start from the understanding that the countries are all very different from each other, and that no single "story" of the impact of the reforms can adequately describe their experiences. First, the countries differ in their accumulated technological capabilities and in the degree of technological maturity present prior to the recent structural reforms, such that their responses were bound to be different. Second, they initiated the 
processes of trade liberalization and market deregulation at different points in time, and they were therefore affected differently by the ups and downs of the international capital market. Finally, they all differ, too, in the depth and internal consistency of their macroeconomic stabilization cum structural reforms policy packages, as well as in the extent to which they received external support during the implementation of these measures. This means that, a priori, large differences can be expected to prevail among the countries with regard to the actual results attained from the application of the structural reform programmes.

Despite such differences, an overall assessment of the impact of the reforms in the macroeconomic policy regime is in order, ${ }^{1}$ as it can demonstrate who has won and who has lost as a result of the changes, how the countries are performing today under a new macroeconomic policy regime and whether the new growth paradigm is actually sustainable. ${ }^{2}$

The approach used in this book draws extensively on Schumpeter's metaphor of the creative destruction processes. Latin America is currently undergoing fundamental changes in the model of production organization, as well as in its institutional and regulatory regimes. As a result of history and accumulated technological capabilities, in combination with recent marketoriented structural reforms, each of the region's societies is going through its own episode of destroying an old, inward-oriented organizational model, while gradually (and painfully) developing a new, more outward- and marketoriented model, whose basic structural features are still being forged and whose long-term behaviour is thus largely unknown. This building-up process is proving to be highly heterogeneous across industries, regions and firms. It also generates social exclusion and can rightly be described as strongly inequitable. I argue here that a study of the emerging issues of structure and performance must be set in a micro-to-macro context, capable of uncovering how different types of firms, industries and regions within any given country have adapted to a new pro-competitive macroeconomic policy regime. Unfortunately, macro-to-micro interdependencies have thus far received little attention in mainstream economics, and many of the issues highlighted here have remained almost unexplored. ${ }^{3}$ From this perspective, the interaction

1. When using the term macroeconomic policy regime in this book, I refer to a combination of fiscal, monetary, exchange rate, and tariff policies together with changes in property rights.

2. The notion of sustainability requires some discussion. It can refer solely to the sustainability of the key macroeconomic prices (exchange rate, interest rate and so on) that stem from a programme of macroeconomic stabilization and structural reform. It can also refer to a broader notion of political sustainability, which is related to the behaviour of other variables such as the unemployment rate or the degree of equity with which the benefits of productive modernization and productivity growth are distributed among the population. The drastic increase in open unemployment or a very inequitable pattern of distribution can militate against the long-term sustainability of the structural reform programme, even if the key macroeconomic prices are kept reasonably close to equilibrium.

3. See Katz (1996). Much research remains to be done on these issues, however. 
between economic, institutional and technological forces -which are not the same for all fields of activity- explains the varying degree to which firms, industries and regions managed to adapt to a more competitive, deregulated and privatized economic regime. Schumpeter's notion of the creative destruction mechanism appears to be an adequate representation of what is presently taking place in Latin America.

Most of the available literature on the impact of structural reforms in the region is of a macroeconomic nature. It consequently fails to capture the enormous role of meso- and microeconomic forces or of institutional and technological variables, which influence the adjustment process of any given economy to changes in its macroeconomic policy regime. Macroeconomic theory is, by definition, blind to the profound degree of heterogeneity that prevails among types of firms (e.g., large domestic conglomerates, local subsidiaries of transnational companies, small and medium-sized familyowned enterprises) or among regions or industries, as well as to the influence such heterogeneity has on the way individual firms, regions or industries adapt to a new macroeconomic policy regime. Such differences in adaptation capabilities have a lot to do with who wins and who loses from structural reforms. By the same token, macroeconomic theory also overlooks the reverse effect, that is, the impact of different microeconomic responses on the longterm sustainability of a given structural reform package. Consider, for example, the case of an inadequate response of exports to a change in the exchange rate. If exports do not grow as much as expected following the devaluation of the local currency (as may have occurred in Brazil in the late 1990s), it could be the consequence of an incorrect exchange rate -or of its rapid appreciation through time- but it could also be the result of a low rate of innovation and productivity growth in the years prior to the devaluation. Looking at the adjustment path exclusively from a macroeconomic perspective almost inevitably leads one to assess the sustainability of the long-term growth path of an economy in terms of its macroeconomic prices (i.e., the exchange rate, the interest rate, and so forth) and to disregard the way in which the underlying institutional and technological forces condition the results of macroeconomic policy changes. Productivity growth seems to depend precisely on these often forgotten underlying forces.

Mainstream economics assumes that opening up to foreign competition and deregulating and privatizing economic activities will necessarily push an economy to a new equilibrium growth path, after a series of short-term adjustments. What concerns the macroeconomist is not the institutional, technological and organizational features of the new production structure, or who wins and who loses during the adjustment process, but the fact that the economy as a whole returns to a long-term equilibrium growth path, with its external and fiscal accounts under control.

Such an approach to the study of growth is highly misleading, however, if the goal is to understand what is happening in Latin America in the present 
transition to a more open, market-oriented and deregulated economic environment. The growth rate of labour productivity has not been sufficiently high in the region over the past two decades, and productivity growth has been highly uneven among industries, regions and firms. Many industries and activities have been seriously disrupted by trade liberalization and by the massive influx of imported substitutes. Moreover, business concentration and the share of transnational corporations in gross domestic product (GDP) have dramatically increased during the adjustment process, which is a clear indication that massive adverse selection and social exclusion resulted from the reforms. Market failures, information asymmetries, the lack of competition policies, the lack of a legal infrastructure defending local consumers and other such "anomalies" of the Latin American economic and institutional landscape account for many of the shortcomings emerging during the transition to a more market-oriented regime.

Such "imperfections" of the price system, or of the institutional infrastructure, had different effects on the adaptive capacity of different types of firms, industries and regions of any given economy, as well as on their transition to the new rules of the game. Consequently, while some parts of the economy have witnessed gradual modernization and technological upgrading, many Latin American countries have also generated large structural unemployment, new forms of monopolistic behaviour and so forth. The relative participation of small and medium-sized enterprises (SMEs) in GDP has fallen, and the economy's external sector has developed chronic longterm weaknesses deriving from the fact that imports are growing much faster than exports. These new issues have become painfully evident in many countries of the region in recent years, undermining some of the significant achievements attained through trade liberalization and market deregulation.

As a result of the above, it is now widely accepted that the expected results from recent structural reforms have only partially been achieved, and that vast sectors of society are being excluded from the benefits of the transition to modernity. New problems of monopolistic practices have emerged; new difficulties associated with the lack of markets and regulatory institutions are obvious throughout the region. Both academic and political leaders are currently searching for a new policy agenda that goes beyond the so-called Washington Consensus (Williamson, 1990) in order to deal with these new issues. The measures under discussion include new regulatory policies capable of better protecting consumers in the recently privatized sectors of the economy; new competition policies capable of securing an adequate functioning of markets now that mergers and acquisitions have become a prominent feature of the region's economies; new production and innovation policies capable of enhancing the productivity growth rate and international competitiveness; and new forms of collective action and clustering at the local and municipal levels capable of inducing synergies and positive externalities. 
Such a new policy agenda seems to demand a number of institutions that are a normal feature of mature capitalism, but that are often lacking in developing societies. The public and private sectors need to forge a new style of interaction if the long-term efficiency and equity benefits of structural reforms are to eventually reach the vast majority of the population and not just a privileged minority as it presently does (Stiglitz, 1998b).

This book examines some of the recent changes in the performance of the Latin American economies. It explores the links between changes in the macroeconomic policy regime and changes in the pattern of production specialization attained by different countries in the region over time. Many activities and industries managed to consolidate and are doing better than in the past. These include non-tradables sectors producing services such as telecommunications, energy or water sanitation; the natural resource-based industries, which produce commodities such as iron and steel, pulp and paper, and vegetable oil; and the assembly industries (maquiladoras), which produce electronic equipment, video recorders, televisions and clothing, mostly for the United States market. In all of these areas, local subsidiaries of transnational firms and large domestic conglomerates gained participation in the 1990s. Entry and exit of firms in the various markets of the economy were quite significant, as trade liberalization efforts induced a dramatic transformation of each sector's competitive and technological regime. ${ }^{4}$ Although structural reforms were not the only force inducing such changes -institutional and technological forces certainly had an independent role-it is nevertheless true that recent policy changes acted as a major filter, mostly leaving SMEs out of the race. In that process, old forms of organizing production gradually disappeared, being substituted by new management styles and more decentralized, just-in-time and computer-based production arrangements.

Unfortunately, economists have made little progress to date in the understanding and theoretical conceptualization of these processes. Neither their micro-to-macro nature nor the high degree of interdependency among the underlying economic, institutional and technological forces has been addressed in any depth, and many issues remain to be explored. Consequently, the region still lacks a policy agenda that will accelerate the pace of innovation and productivity growth that characterize the individual economies under present circumstances. Approaching this task from a narrowly macroeconomic perspective makes it all the more difficult to understand what is actually going on in the production, institutional and technological spheres of society and what will it take to improve overall performance.

4. The idea of sectoral technological regimes has recently been examined by Carlsson (1995), Malerba (1997) and Ferraz, Kupfer and Hauguenauer (1995). My use of the term is clearly linked to that proposed by these authors. 
The book is divided into seven chapters, which are organized into three parts. Part One (chapters I and II) presents the micro-to-macro analytical framework that underlies the research. The literature on technological change does not provide a satisfactory micro-to-macro explanation of the sources of productivity growth or why specific industries, regions and firms in a given economy modernize over time. Despite the fact that questions of economic growth have been central to the economics profession since the time of Adam Smith, we still lack a universally accepted theory in this field.

At least three schools of thought contest this issue. Chapter I briefly reviews these, together with their individual contributions to an understanding of the growth process. It also posits the need to study macroeconomic and microeconomic variables together in an effort to grasp how economic, institutional and technological forces condition the process of catching up or lagging behind experienced by any given country, industry or region during periods of growth.

Chapter II centres on specific micro- and macroeconomic aspects of the restructuring process that stemmed from changes in the macroeconomic policy regime. The chapter argues that the process entails a profound change in relative prices as well as in society's institutional and regulatory environment. The impact of these changes varies across countries and fields of economic activity. The devaluation of the local currency, for example, favours exportoriented, natural resource-based industries. At the same time, it erodes the competitiveness of import-substitution industries geared primarily towards the domestic market, as these industries normally operate with a high proportion of imported inputs (which become significantly more expensive after the devaluation). The Latin American capital goods producers have therefore been negatively affected; they have had difficulties confronting new external competition after recent trade liberalization efforts and have lost participation in domestic markets and exports.

Chapter II also argues that macroeconomic policy changes have prompted the entry and exit of firms in almost every other activity. This process has significantly altered market structure and performance at the individual industry level and generated new sectoral technological and competitive regimes which are still very imperfectly understood.

These intra-industry episodes of structural transformation have been accompanied by inter-industry changes that are gradually altering the overall pattern of production specialization attained by each of the economies in the region. This second phenomena is reflected in shifts in the relative weight of the various production activities in GDP. Many countries in the region show a gradual but steady change of this sort beginning in the 1970s. Two main models have been consolidated. The first entails a clear specialization in natural resource-based industries that are highly capital intensive in nature and feature very low domestic value added. This pattern of specialization prevails in Argentina, Brazil and Chile, where the leading manufacturing sectors are those 
that produce basic commodities such as iron and steel, pulp and paper, vegetable oils, aluminium and fishmeal.

Mexico and some of the smaller Central American economies have proceeded along a different route. They have specialized in assembly industries (maquiladoras) that mainly cater to the United States market, producing goods such as garments, video cassette recorders, televisions and computers. In many of these industries, nearly $98 \%$ of the value of production consists of imported parts and components that are immediately re-exported after being assembled into final goods. These activities, like the processing of natural resources, are characterized by low domestic value added, although with the passage of time and the spread of just-in-time production practices, some firms have developed in-house engineering capabilities on the basis of which to handle quality control and logistics. ${ }^{5}$

Both models of production specialization -the capital-intensive, natural resource-based model of the Southern Cone countries and the maquila-based model of Mexico and many smaller Central American countries- have done well over the last two decades and have attained rapid growth. The same is true of non-tradables sectors such as telecommunications, energy, transport and water and sanitation services. The automobile industry is another successful performer: it received preferential treatment from the economic authorities in all the countries in the region and therefore managed to grow faster than average, irrespective of the trend towards market liberalization and deregulation imposed on the rest of the economy. In contrast, labourintensive industries producing wage goods, such as shoes, garments and furniture, and research and development $(R \& D)$ and engineering-intensive industries producing capital goods, machine tools and pharmaceutical raw materials have done rather badly during the structural adjustment process.

In sum, trade liberalization, market deregulation and privatization, together with historical trends, have led to the gradual consolidation of new patterns of production specialization throughout the region. The new leaders are natural resource-processing industries, maquiladoras, non-tradable goods and, finally, the auto industry, which managed to receive preferential treatment throughout the region. This transformation in the pattern of production specialization was not necessarily caused by the structural reforms, as the evidence shows that it was already underway in the 1970s, long before the implementation of the structural reforms actually began. The reforms certainly accelerated the process, however.

5. It is perhaps excessive to identify Mexican industry exclusively with the maquila model. Significant specialization has also occurred in basic industrial products such as cement, beer and glass, in which large national conglomerates have undertaken substantial expansion programmes in recent years (Dutrenit, 1998). Given the dominant pattern, however, stress is placed here on Mexico's currently leading role in maquila industries. On the technological content of third-generation maquilas, see Buitelaar, Padilla and Urrutia (1999) and Alonso, Carrillo and Contreras (1999). 
Part Two of the book looks at the available empirical evidence on technical change, innovation and productivity growth. It also examines the impact of recent structural reforms on three indicators: (i) job creation, (ii) the comparative performance of SMEs and large companies and (iii) the new structure and behaviour of the region's external trade accounts for manufacturing. Countries have become heavy importers of capital goods and intermediate inputs for manufacturing production, while they have increased their exports of products with low value added. Can they successfully maintain balanced external accounts under such conditions? Should policy measures be adopted to change the production and export mix?

Chapter III starts by examining labour productivity growth in various countries of the region, including an analysis at the three-digit level of aggregation of the International Standard Industrial Classification (ISIC) for 27 different industries in Argentina, Brazil, Chile, Colombia and Mexico. The chapter then compares the Latin American indicators with the corresponding figures for the United States over the same period. The aim is to see whether the productivity gap is narrowing or if, alternatively, it is increasing through time. This part of the study seeks to answer several questions. What are the observed long-term differences in performance between countries and industries in the region? How much improvement was attained in the 1990s relative to previous decades? Which are the successful sectors and which are the laggards in the various countries of the region?

This chapter shows that some industries are indeed converging with the international productivity frontier. The recent structural reforms, however, cannot be regarded as the ultimate cause of such convergence. A great deal also occurred in this respect during the import substitution industrialization (ISI) period, particularly in countries such as Argentina, Colombia and Mexico. In other words, history matters, and the technological knowledge some of the countries accumulated during the ISI period is a central component of many catch-up stories now observed vis-à-vis the international technological frontier.

Chapter IV explores labour productivity and technological change in nonmanufacturing activities, concentrating on mining and telecommunications. The chapter shows that the process of technological modernization and the closing of the productivity gap found in some fields of manufacturing can also be found in these non-industrial activities.

Much of the technological modernization that occurred in these sectors is frequently attributed to privatization and the entry of new large foreign firms into the economy. As was to be expected, the entry of foreign operators brought about a radical change in the structure and performance of these activities, as well as their rapid technological modernization.

Not all the countries of the region followed the same route, however, of using privatization as a means of modernizing public utilities or the mining industry. In some cases, such as the Corporación Nacional del Cobre de Chile 
(CODELCO), the Instituto Costarricense de Electricidad (ICE), or the Administración Nacional de Telecomunicaciones de Uruguay (ANTEL), the decision was made to retain the firms under public ownership but concomitantly to force them into modernization and technological upgrading by exposing them to stronger competition. This option usually triggered a healthy response from the public firms, which proceeded to implement major actions on the technological and organizational front. This suggests that it is not necessarily privatization per se, but rather the gradual introduction of a new, more competitive culture and discipline, that induces modernization and technological upgrading. At the same time, consumer protection and the enforcement of competition policies seem to have been somewhat easier in these cases than in those in which large foreign firms attained a strong market position in the domestic market. Domestic consumers often paid a high price for the transition to a more privatized production structure when this took place under monopoly conditions.

Part Three of the book addresses policy issues. What must the countries of the region do to accelerate their productivity growth rate, improve labour absorption and move towards a more equitable pattern of distribution of the benefits of the transition to a more open, deregulated economy? This part of the book consists of two chapters. Chapter VI discusses three main institutional topics that condition what might be attempted in the near future with regard to public policy: (a) the new international trade disciplines emerging from the Uruguay Round (1994) of the General Agreement on Tariffs and Trade (GATT), with which the Latin American countries will have to comply; (b) the new market-oriented ideology now prevailing across the region, which makes it very difficult to discuss industrial policy issues in a dispassionate way; and (c) the major recent changes in the region's innovation systems, which affect future capabilities for generating endogenous technical progress and productivity growth. In the years ahead, all three institutional constraints will influence what countries can and want to achieve in the direction of "reforming the reforms" as they seek to enhance their international competitiveness and the equity consequences of the transition to more open, deregulated regimes.

Finally, chapter VII examines a possible agenda of future interventions. Issues such as structural unemployment, chronic trade deficits in manufacturing and the lack of opportunities for SMEs to join the modernization process have to be addressed by future policy makers. There is a need to create markets where they do not exist, as in the case of long-term financing for SMEs. There is also a need to correct for market failures wherever externalities, public goods and other so-called anomalies make current prices a particularly bad proxy for equilibrium prices. Similarly, there is an urgent need to create new regulatory agencies and judiciary systems capable of implementing stronger competition policies and consumer protection actions 
in the recently privatized areas of the economy, where weak antitrust legislation has led to large rents and monopolistic practices. There is also an urgent need for innovation policies that can help develop domestic technological capabilities that would accelerate the process of catching up with the international productivity frontier. Finally, collective action capable of generating externalities and synergies at the local and municipal levels should also be promoted as part of the new policy agenda.

In all of these areas, the countries of the region should, in the near future, explore new patterns of interaction between the public and private sectors, experimenting with new institutions in order to identify by trial and error what works and what does not. Uncertainty and imperfect information make it impossible to know a priori exactly what will be effective in each particular country, industry or region, and countries must therefore proceed through learning by doing in the field of policy design and implementation. Very different types of capitalism coexist around the world. The Scandinavian model is one. That of the United Kingdom is another -and no less capitalist, for that matter. There are also Canadian, French, Israeli and Italian variants. The relation between the State and civil society is very different in each of the above models of social and market organization. Countries differ in the degree to which they establish safety nets for social protection and in the extent to which they defend local identities, counteracting adverse selection. It is still too early to predict the true, long-term face of Latin American capitalism. The processes of opening up to foreign competition and of deregulating and privatizing economic activities have barely begun, and it is already clear that the Argentine brand of capitalism is going to be different in the long run from the Chilean or Brazilian models, for example. The construction of citizenship, the development of domestic production and technological capabilities and the transition to a knowledge-based economy will surely follow very different routes in each national context. The discussion of what lies ahead in each country will be lengthy and difficult. This book seeks to contribute to the debate on these issues. 


\section{Part One}

THEORETICAL FRAMEWORK 



\section{CHAPTER I \\ ECONOMIC, TECHNOLOGICAL AND INSTITUTIONAL FORCES CONDITIONING INVESTMENT AND INNOVATION}

This chapter examines the influence that macro-, meso- and microeconomic forces have as determinants of investment and innovation. ${ }^{6}$ It also explores the coevolution of economic, technological and institutional forces conditioning such behaviour. Only after exploring such interdependencies is it possible to proceed with the study of how the recent structural reforms have affected Latin American economies during the course of the last two decades.

Conventional neoclassical theory gets around many of the complexities of these processes by convenient simplifying assumptions. Institutions -apart from the market itself-do not play any role at all, and technology is regarded as an exogenously given, freely available and perfectly understood set of blueprints that the individual businessperson can find on some existing shelf. The explanation of the innovation process revolves around the notion of the representative firm, which is a highly stylized and very simple description of what a firm actually is. Specifically, the neoclassical firm is completely rational, always understands what needs to be done and always does exactly what is best, given exogenously determined circumstances. It has access to perfect

6. The present theoretical framework has much in common with the one employed by Moguillansky and Bielschowsky (2000) to study investment behaviour in Latin American economies. Both works are part of a wider research program undertaken by ECLAC to examine the impact of recent structural reforms throughout the region. For an overview of the program, see Stallings and Peres (2000). 
factor markets that supply the optimal factor quantities at equilibrium prices. Knowledge is a free good to which the firm has instant access without incurring adaptation costs. There are no direct interdependencies, externalities or synergies, such that price signals are a true reflection of the firm's marginal cost of production and of the marginal benefit consumers receive from spending their money.

When receiving the Nobel Prize in Economics at Stockholm, Robert Solow described the neoclassical metaphor as follows (Solow, 1988):

The idea is to imagine that the economy is populated by a single immortal consumer, or a number of identical immortal consumers.... [This consumer] is supposed to solve an infinite time utility-maximization problem.... For this consumer every firm is just a transparent instrumentality, an intermediary, a device for carrying out intertemporal optimization subject only to technological constraints and initial endowments. Thus any kind of market failure is ruled out from the beginning, by assumption. There are no strategic complementarities, no coordination failures, no Prisoners' Dilemmas.

The end result is a construction in which the whole economy is assumed to be solving a Ramsey optimal-growth problem through time, disturbed only by stationary stochastic shocks to tastes and technology. To these the economy adapts optimally. Inseparable from this habit of thought is the automatic presumption that observed paths are equilibrium paths. So we are asked to regard the construction I have just described as a model of the actual capitalist world.

In an analytical context of this kind, technological knowledge as a factor of production and learning as a process by which the firm accumulates experience acquire a highly simplified specification, which does not take into account either uncertainty or the fact that knowledge has many attributes of a public good. In the neoclassical world, knowledge is always completely written and codified, and it never demands experimentation, research or trial and error. Learning thus becomes entirely predictable and formalistic, free of failure or uncertainty. The neoclassical firm behaves as a robot, with no individual habits and routines; this conceptualization is unable to accommodate the rich body of organizational knowledge featured in other interpretations of the firm (Penrose, 1951; Chandler, 1990).

Despite these limitations, the neoclassical simplification is useful in that it facilitates the aggregation of individual firms into a collective construction called industry to which is assigned an imaginary average collective behaviour. This is obviously an artefact, but it does provide a map of reality at a manageable scale, although in the process of aggregation it loses the details 
of the topography it aims to describe. If the purpose of enquiry is precisely to examine these topographical details, then the neoclassical map may not be the best one available.

Various authors have developed non-conventional approaches for exploring many of these issues, including Bain $(1956,1966)$, Scherer (1980), Simon (1955, 1959), Chandler (1990) and the so-called evolutionary or neoSchumpeterian scholars such as Freeman $(1974,1994)$, Dosi $(1982,1988)$ and Boyer $(1986,1991)$. These authors set aside the neoclassical notions of equilibrium and the representative firm, coming much closer to reality as they try to understand microeconomic behaviour under conditions of imperfect information, uncertainty and the search for new production routines. They conceptualize knowledge as an incomplete set of blueprints whose components have to be discovered through trial and error and the accumulation of experience.

The neoclassical model presents a stylized analytical discourse of a deductive nature, which is clearly at odds with the inductive, empirical stand taken by industrial economists and evolutionary scholars. Neoclassical economists can thereby operate with a clear-cut description of the microeconomic foundations of macroeconomic models. They can then proceed quite easily with the notion of an aggregate equilibrium growth path, which is precisely what evolutionary economists are unable -and unwilling- to describe. For them, the economy functions in a perpetual state of imbalance and is not proceeding towards a "meta" equilibrium path.

Figure I.1 presents a stylized overview of the forces involved, which can help distinguish the conceptualizations of the growth and innovation processes offered by the different schools of thought. The figure highlights the role that macro-, meso- and microeconomic variables play as determinants of innovation and investment in any given economy. The upper right-hand box identifies the conventional macroeconomic forces that affect investment and innovation decisions, while sectoral and microeconomic variables are shown in the upper and lower left-hand sections. As mentioned above, neoclassical authors pay little attention to this second set of variables, instead explaining productivity growth in terms of savings and investment, capital accumulation and factor substitution processes induced by changes in relative factor prices, as well as by exogenous technical progress.

In contrast, the non-neoclassical explanation of productivity growth is far more complex, and it is informed by institutional and socio-anthropological factors that are completely alien to the neoclassical growth story. This approach broadens the analytical framework for understanding the evolutionary path of any given economy to incorporate the institutional and organizational forces that underlie the growth process. In an evolutionary analytical environment, the firm is influenced not just by conventional macroeconomic variables, but also by forces deriving from the highly specific, localized institutional 
Figure I.1

\section{DETERMINANTS OF TECHNOLOGICAL CHANGE}

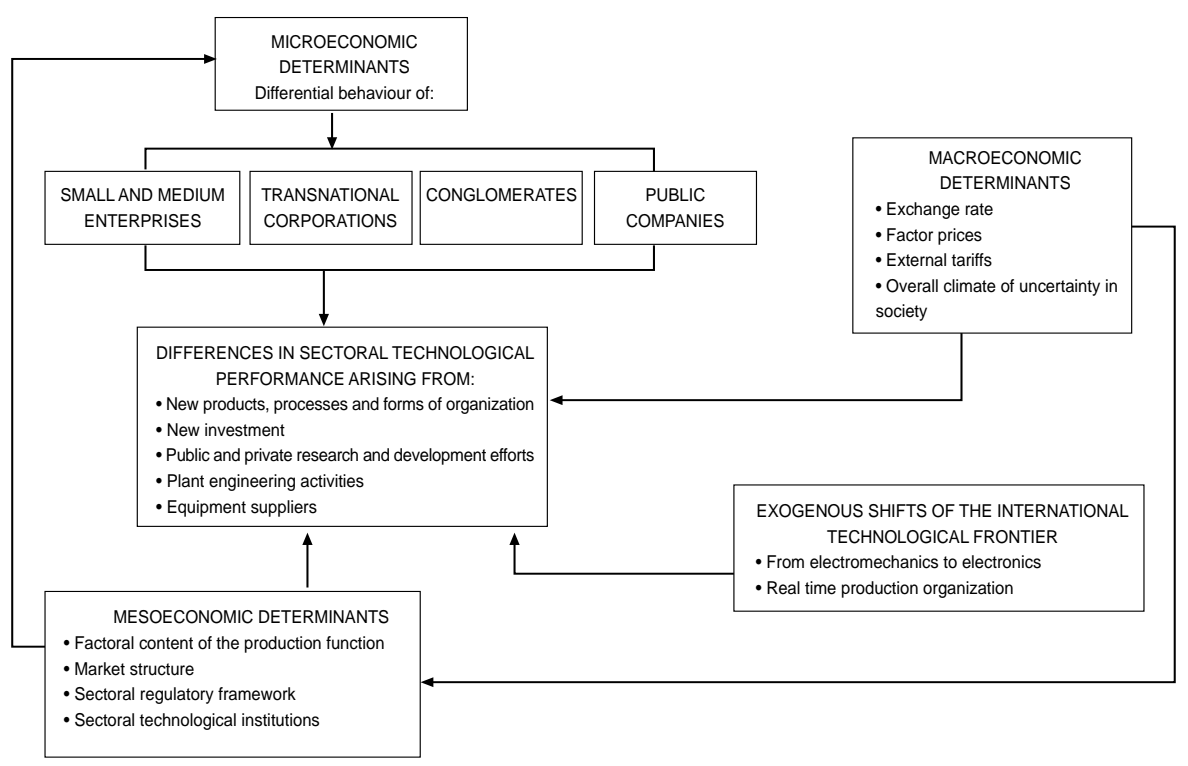

environment in which the firm has to operate, that is, by forces which are important at the sectoral or local level, but which lack significance for the economy as a whole. Intellectual property rights, sectoral technological agencies and institutions, research universities or banks belong in this particular group of determining factors, and they clearly affect individual firm behaviour in the growth story told by evolutionary economics.

In addition to macroeconomic variables, therefore, other forces -often of a sectoral nature-need to be taken into account as determinants of investment and the innovation process and of the propensity of individual firms to invest and innovate.

Thus far, the discussion has mainly focused on the links between macromeso- and microeconomic variables as determining forces of firm behaviour. The next question is how such behaviour would respond to changes in the key macroeconomic prices of the economy (i.e., the exchange rate, the interest rate, the real wage rate) as well as in the institutional and regulatory environment, as a consequence of the application of a macroeconomic stabilization cum structural reforms policy package. 
Such a package necessarily entails a drastic change in the set of relative prices prevailing in the economy, as well as in the institutional and regulatory framework within which individual firms operate. Policy packages of this sort are normally implemented precisely with the purpose of sharply altering the existing set of incentives in an attempt to correct a situation of extreme macroeconomic imbalance, with the external and fiscal accounts out of control. This environment raises the degree of uncertainty and deteriorates the confidence of the domestic and international business community. Consequently, the propensity to invest and innovate falls quite significantly; firms are concerned about short-term considerations, such as protecting their cash flow or limiting their exposure to inflation, and they are wary of taking long-term decisions surrounded by uncertainty, such as installing new production capacity or introducing product or process innovations. It is reasonable to assume that under such circumstances firms tend to abandon projects that involve an extended planning horizon and to concentrate on short-term survival strategies.

\section{A. The Three Phases of a Macroeconomic Stabilization and Structural Reform Policy Programme}

An episode of macroeconomic stabilization cum structural reform develops through three different phases. These range from an initial phase of extreme macroeconomic turbulence, in which savings and investment rates fall and the level of economic activity declines, to a final stage in which the external and fiscal accounts become more manageable and closer to equilibrium in the context of a clear revitalization of the savings and investment rates. At that point, entrepreneurs' "animal spirits" emerge once again. Figure I.2 presents a simple, stylized illustration of the situation.

During phase I, the economy's capacity for honouring its external debts appears to be severely damaged. The public sector is strongly underfinanced and has to borrow from the Central Bank, from local capital markets or from external sources. It is forced to offer a higher (and increasing) interest rate in order to get access to funds in an economic environment that is growing more uncertain by the day.

Under such conditions, the economy gradually settles into a pattern of recession and inflation, which has varying effects on the different sectors of the economy and even on different firms within any given sector of economic activity. With regard to the former, those sectors that are closest to the natural comparative advantages of the country tend to react best to a change in the macroeconomic policy regime. The macroeconomic stabilization programme usually involves a devaluation of the exchange rate, which generates a better 
Figure 1.2

\section{PHASES OF THE ADJUSTMENT PROCESS}

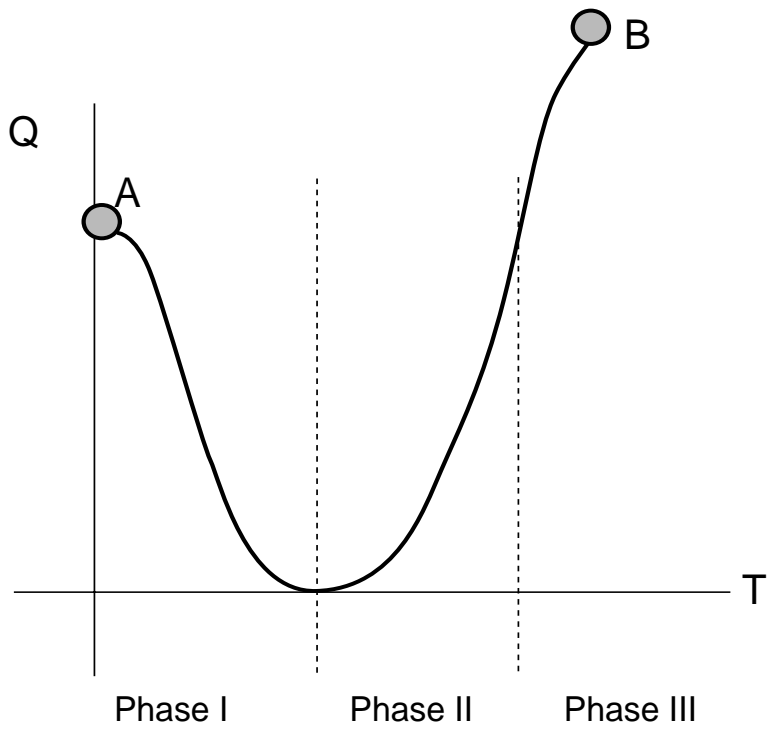

response from export-oriented, natural resource-based industries than from import-substitution industries catering to the domestic markets.

With regard to differences among firms within a given sector of economic activity, it seems reasonable to expect that firms will react defensively to the prevailing circumstances by trying to reduce production costs, gain flexibility and liquidity and avoid medium- or long-term commitments. It is crucial for any given firm to reduce its exposure to inflation; it therefore minimizes sales on credit, stocks of intermediate parts and so forth. Obviously, some firms will find it easier to respond than others, and they will be more successful in carrying out such changes.

The following empirical evidence supports this argument. Chile implemented a structural reform package in the early 1970s, following the military takeover that brought Gen. Pinochet to power. The resulting contraction in the level of economic activity and the simultaneous massive arrival of imports after tariff reductions caused a large number of firms to exit the market, and the unemployment rate reached more than $20 \%$ of the labour force. Between 1974 and 1982, 7,000 industrial firms closed down in Chile, during what must be considered the first phase of the Chilean macroeconomic stabilization process. This is about $16 \%$ of the total number of industrial firms registered at that time by the National Institute of Statistics. Most of the firms that shut down were medium-sized enterprises involved in the production of 
wage goods, such as garments and shoes, and metalworking firms producing simple capital goods and consumer durables. The case of Argentina is in no way different. About 15,000 firms closed down during Argentina's macroeconomic stabilization process in the late 1970s, and the size and sectoral distribution of the exiting firms is similar to that observed in Chile.

In the simple model presented in figure I.2, the initial phase of intense macroeconomic uncertainty and imbalance tends to be followed by a second phase in which the stabilization process begins to operate. The trade deficit declines as imports fall and exports grow. The loss of reserves is brought under control. The inflation rate drops, and the interest rate begins to come down. Such events constitute clear signals that a gradual recovery is underway and that the internal market is starting to grow again.

In that context, firms become alert to future business opportunities. The process is slow at first, but it acquires strength as the overall level of economic activity expands. Central to second phase is the gradual increase in the use of installed production capacity, although this does not necessarily mean that firms are undertaking new investment decisions. How long the defensive mood will last is difficult to tell a priori. Many other institutional issues might be at work, conditioning the way a given firm reacts to events in a gradually stabilizing economy.

It is only in the third phase of the adjustment process that the economy begins to show clear signs of the long-term sustainability of the new set of relative prices, and the business community gradually becomes proactive again. The country's international risk rating tends to fall, and savings and investment, as well as foreign flows of non-speculative capital, begin to grow again. Firms are now more prepared to undertake new investment programmes to expand installed capacity, hire new labour and realize longterm innovation efforts. The latter are linked to the launching of new products and the installation of new production processes. The opening of new production capacity appears as the clearest indication that the economy has regained stamina and that animal spirits are back in place.

This simplified description of the three phases of an adjustment cycle illustrates two important points. First, when macroeconomic stabilization and structural reform come together (as was the case in several countries in the region in the 1970s and early 1980s), firms must simultaneously cope with the contraction of the domestic market, on the one hand, and the massive arrival of imports (due to the reduction of tariffs), on the other. The difficulties prompted by these two circumstances are exacerbated when firms must also adapt to a new macroeconomic policy regime in which many subsidies are eliminated and competition from external sources becomes a daily fact of life.

Second, although macroeconomic forces do matter, sectoral and microeconomic considerations clearly play a very important part in explaining why, under the same set of circumstances, some firms forge ahead and cope with the new circumstances while others simply fail to do so and eventually 
must exit the market. Sectoral and microeconomic forces that might have little or no significance at the macroeconomic level thus constitute a key factor causing certain industries (and firms) to do better than others after a change in the macroeconomic policy regime. Economists have recently begun to develop the concept of sectoral technological regimes (Malerba, 1997) in order to identify a specific cluster of localized forces and economic actors-firms, banks, technical schools, public research and development institutes, chambers of commerce, and so forth- that jointly master a set of technological disciplines, forms of human resource training, and styles of communication and interaction, which provide the underlying social capital to support the functioning of specific sectors of economic activity. The interaction between all these actors is regulated by explicit and implicit rules, conventions and habits which are broadly understood by the members of the cluster. This concept of "sectoral institutions" is pertinent to the arguments developed in this book.

\section{B. Changes at the Meso- and Microeconomic Levels during the Different Phases of the Stabilization and Structural Reform Programme}

We have thus far presented a very simple, stylized description of the changes that take place at the macroeconomic level during the various phases of a broad structural reform programme. A question comes immediately to mind. Should we expect all sectors of production and economic activity to react equally to the new macroeconomic policy regime, or should we a priori expect the impact to be different across firms and sectors?

Sectors of economic activity differ in the factor intensity of their respective production functions as well as in terms of the underlying institutional environment in which they operate. Some, such as the natural resourceprocessing industries, make intensive use of natural raw materials; property rights to these resources -e.g., mines and forests- seem to be a crucial factor in the decision making of firms in these sectors. Other sectors make intensive use of unskilled labour, as in the case of industries producing garments, footwear or furniture. A third subset of industries includes all sectors that make intensive use of engineering services and technological knowledge, and here intellectual property rights seem to be the prime consideration. The typical sectors in this group are those producing pharmaceutical raw materials, capital goods, machine tools and other similar knowledge-intensive products. Given these differences in the factor content of the respective production functions and in the institutional environment, it seems reasonable to expect that the various activities will be affected differently by changes in the exchange rate, the interest rate, the real wage, the degree of tariff protection and the regulatory environment. 
Further research confirms this a priori perception. Natural resource-based industries that are geared to the production and export of industrial commodities have benefited the most from trade liberalization efforts and have significantly improved their insertion in world markets. These sectors include pulp and paper, vegetable oils, iron and steel, aluminium and fishmeal. In addition, the assembly industries (maquiladoras), which mainly operate under the control of large United States, Japanese and Korean multinational firms, and the automotive industry, which has enjoyed preferential treatment from various governments of the region, have also managed to grow well under the new rules of the game.

The sectors that have suffered the most from trade liberalization and market deregulation measures are those producing capital goods, pharmaceutical raw materials and other knowledge-intensive goods and services. Other sectors that have lost out include those producing non-durable consumer goods like footwear, clothing or furniture, all of which are intensive users of unskilled labour. Small and medium-sized family enterprises (SMEs) figure prominently in all of these lagging sectors. The exit of firms - particularly SMEs- has been significant in these industries, where the massive arrival of imports has significantly damaged the competitive position of domestic enterprises.

A simple model can be used to describe the adjustment process of any given industry in which domestic demand contracts at the same that imports flood in as a result of tariff reductions. The model quite closely reflects developments in sectors such as footwear, clothing, textiles and machine tools (Katz, 1986; Katz and Vera, 1997; Kassai, 2000).

Imagine an industry in which one large leading company co-exists with a number of smaller companies that produce imperfect substitutes for the goods made by the leader. Given high import tariffs, the price of the imported substitutes is very high. Hence they are not marketed locally at the start of the sequence of events to follow. The model incorporates three actors: a large company, many SMEs producing substitutes for the product of the large firm and the (potential) importers.

Changes in relative prices following macroeconomic stabilization and structural reform efforts have three effects: (i) a downward movement of the demand curve; (ii) an increase in the average and marginal cost curves of the various producers; and (iii) a decline in import prices due to tariff reductions. The price of imported substitutes falls, and imports now enter the market. At the same time, the recession triggered by higher interest rates causes aggregate demand to fall, which forces firms to search for ways to reduce costs in an effort to defend their market share.

What are the dynamics of the case described in the model? As the price of imported substitutes falls, imports tend to flood the market. Demand contracts, and the demand curve moves inwards. Local production costs 
increase, and domestic firms must simultaneously adapt to a fall in demand and to the entry of cheaper imports. Some manage to lower their costs by rationalizing production practices and laying off workers, but others are incapable of doing so. To facilitate the analysis, assume that only the oligopolist has accumulated technological capabilities on the basis of which to introduce labour-saving organizational changes in its plant, thereby lowering production costs. The remaining firms in the industry are gradually forced to leave the market. Only two actors remain at the end of the sequence: the importers and the large company, which has managed to reduce costs by means of disembodied technical changes, without undertaking major new investments. The share of imports in total supply increases significantly as small companies are forced to leave the market. ${ }^{7}$

As already mentioned, once the macroeconomic adjustment process begins to gain ground, inflation slows under the pressure of imports, the fiscal and external deficits are brought under control, and internal demand gradually picks up. Real wages begin to recover, and GDP begins to grow.

The new structural conditions, however, preclude a return to the previous market structure. Imports now control a significant share of the market, and only a few firms managed to survive the transition process, lowering their costs mainly by reducing their wage bill. Many firms -mostly SMEs- were forced to close during the crisis.

It is in the third phase of the macroeconomic stabilization and structural adjustment programme that the market begins to expand again. The demand curve moves outwards, prompting proactive investment behaviour on the part of surviving firms. This leads to the installation of new production capacity, the modernization of plants, and the launching of new products that are closer to the international state of the art. The domestic market -and not just exports-again becomes attractive to local firms and begins to operate as an engine of growth. This stimulates investment and technological modernization in local firms geared towards meeting renewed domestic demands.

The new market structure tends to consolidate in the third phase. The firms that managed to survive the crisis now share the expanding domestic market with the importers. The substantially increased share of imports, the exit of many small firms, the growth of installed capacity and the technological modernization of a few firms in the industry are central features of the new market situation generated by the application of the macroeconomic stabilization and structural reform programme. Under the new circumstances,

7. There have been many cases of regulated liberalization in which the oligopolist (the large firm in the initial situation) is granted exclusive legal authorization to import, as in the automotive industry. This obviously reduces the disciplining role of external supply in the local market, and prices do not fall to the degree that they would with unrestricted liberalization. 
both the average plant size and the degree of business concentration increase, and the industry moves into a new competitive and technological regime that differs significantly from the previous one.

Why are some companies able to survive and to sustain their long-term competitiveness, despite the fact that they do not undertake new investment or technological modernization efforts during the first two phases of the stabilization programme? As shown in chapter II, firms with very different levels of operational efficiency co-exist within a given industry at any point in time. Changes in relative prices therefore do not affect all firms in the same way. When the price of imported substitutes falls, some firms are unable to cover their variable production costs, and they are forced to stop production before other firms do so. Their exiting the market leaves room for imports and, to a lesser extent, the remaining domestic firms to increase their share of total sales. Greater accumulated technological capacity clearly improves some firms' chances of adapting to the new market conditions by reducing costs, simplifying product ranges or implementing other measures aimed at gaining economies of specialization. Similarly, not all firms have the same access to the necessary financing and technology for restructuring their plants and modernizing their product design. Market failures in the supply of long-term financing to SMEs appear here as a major source of difficulties in the adaptation processes.

A range of circumstances thus explains why some firms survive the transition towards a more competitive market environment while others do not. Some of these circumstances reflect the role of accumulated technological capacities at the level of the firm. Others reflect market imperfections that lead to exclusion or adverse selection. Specific characteristics of the domestic market, such as geographical isolation and small size, also seem to aid survival, as these factors entail high transport costs that discourage would-be importers from entering the market after tariff reductions have been enforced. Finally, company survival in Latin America also seems to have depended quite strongly on opportunistic behaviour and financial speculation on the part of individual firms in response to the high degree of macroeconomic uncertainty and turbulence (Mizala, 1992). "Rough waters favour the fisherman," says the proverb, and its validity seems to be confirmed by the fact that a firm's chances of surviving were clearly influenced by windfall gains obtained from speculative activities in a non-transparent, highly volatile economic scenario.

As macroeconomic stability is restored, entrepreneurial spirit revives and some firms begin to explore the possibility of investing in new production facilities. The new balance between local production and imports tends to stabilize. Only a few local companies survive the transition to the new market environment. From this perspective, recent trade liberalization efforts can be said to have acted as a winnowing mechanism, bringing about a new market structure and competitive and technological regime at the sectoral level. 
The economics profession clearly lacks a good macro-to-micro theory with which to understand situations of this sort. Furthermore, it lacks a theory of "business demography" to explain the entry and exit of firms in the market, which would identify who wins and who looses in these situations and why this happens. The available empirical evidence seems to indicate that the surviving firms in each market were not necessarily the best ones.

Much of the previous discussion is based on lessons derived from individual case studies, which show remarkable regularity across industries and countries, regardless of whether they involve the manufacturing of footwear, furniture, machine tools or clothing. The generalized interdependencies between macro- and microeconomic processes and the joint impact of economic, technological and institutional forces are clearly evident. Trade liberalization and market deregulation efforts carried out in the context of large-scale market failures in factor markets and asymmetric information across firms have caused a dramatic transformation of sectoral competitive and technological regimes. Economic concentration has increased, as has the exit of small and medium-sized family firms from almost every market. These circumstances help explain the highly chaotic nature of the process under examination. To date, economists have made little progress in explaining this complex set of interdependencies and remain rather blind to the microeconomic consequences of the reforms.

\section{Failure of the Macroeconomic Stabilization Efforts}

The preceding section presented the main features of the stages through which an economy can be expected to proceed in response to a structural reforms policy package, together with the likely reaction of individual firms. The analysis obviously entailed a simple, stylized sequence which did not address the many circumstances that could go wrong in the process of implementing the adjustment programme, thereby throwing the economy off its long-term stabilization path. In fact, many programmes of this type have failed as a result of both internal inconsistencies and significant changes in the general conditions under which they were intended to operate.

In his study of the Brazilian economy, José Carlos Miranda notes that from 1981 to the early 1990s, Brazil implemented nine stabilization plans, 15 wage policies, 19 changes to the exchange regime, 22 proposals for the renegotiation of the foreign debt and 20 fiscal adjustment programmes. "These failed adjustments show how difficult it has been for the Brazilian economy to secure fiscal, monetary and exchange equilibrium simultaneously" (Miranda, 1996). Why has it been so difficult to perform well on this front?

In a recent study, Ricardo Ffrench-Davis and Stephany Griffith-Jones identify a number of macroeconomic and microeconomic factors, both internal 
and external to any given economy, that influence the process of structural adjustment and that can cause macroeconomic stabilization efforts to fail. These authors detect at least five reasons why this might happen: "First, external capital flows should consistently go to augment aggregate investment and not be diverted to consumption. Second, an aggressive domestic savings effort is called for: from the outset of a debt cycle, the marginal savings rate must be kept at a level that is much higher than the country's average savings rate and also considerably greater than the investment rate.... Third, the investment must be efficient. Fourth, the country must aggressively invest in tradable goods in order to be able to create a trade surplus large enough... so as to service the debt. Fifth, creditors must be willing to provide stable and predictable flows of finance on reasonable terms." They go on to add: "These conditions may not all be complied with in practice. Countries may experience an ongoing substitution of domestic savings by foreign savings; investments may not always be efficient or channeled sufficiently into tradable goods, and creditor behavior may differ from the desired pattern" (Ffrench-Davis and Griffith-Jones, 1995, p.228). In other words, many things can go wrong during any given macroeconomic stabilization and structural reform programme, thereby creating new imbalances in the economy and renewing macroeconomic uncertainty.

Miranda (1996) and Fanelli and Frenkel (1996) go a step further in analysing the micro- and macroeconomic interdependencies involved. They argue that a series of failed attempts to stabilize the macroeconomy could eventually generate long-term defensive attitudes among individual firms. According to Miranda, "Macroeconomic uncertainty and the failure of various attempts at stabilization in Brazil beginning in the early 1980s provoked adaptive behaviour among both firms and economic institutions. In the end, the preferred option among firms was to adopt defensive actions. A vicious circle was thus established, whereby macroeconomic imbalances and defensive microeconomic actions ended up by retrofeeding on themselves." (Miranda, 1996, p.174). Frenkel and Fanelli note that macroeconomic instability leads firms to operate with a low-risk, highly conservative portfolio of choices that tends to be suboptimal from the viewpoint of a long-term growth strategy. Miranda concludes that an economy-wide regime of this sort ends up stimulating rent-seeking microeconomic strategies. ${ }^{8}$

The essence of the interdependencies between the micro- and macroeconomic spheres emerges quite clearly. The former is not solely a neutral

8. It should be noted, however, that structural reform efforts are not always undertaken in combination with macroeconomic stabilization programmes. The two were implemented together in Argentina and Chile in the 1970s, but not in Argentina or Mexico in the 1990s. 
sounding board of macroeconomic disequilibrium, as macroeconomists sometimes think. Rather, it acts as a dynamic factor in its own right, reinforcing critical components of aggregate disequilibrium. The length and depth of the contraction of GDP following the application of a macroeconomic stabilization and structural reform programme depend to a large extent on how the various economic activities react through time to changes in the macroeconomic policy regime. If the objectives of the programme are inconsistent with the instruments used by the economic authority, then the programme will eventually fail. Also, if the global context changes significantly -the Brazilian devaluation, for example, in the case of Argentina- the inconsistency between the parameters of the adjustment process and the expected results will immediately become clear.

\section{Coevolution of Economic, Technological and Institutional Forces During the Structural Adjustment Process}

Classical economists took for granted the idea that a complex network of interdependencies among economic, technological and institutional forces provides the backdrop for the long-term growth of any given economy. The first three chapters of Adam Smith's Wealth of Nations are devoted to an examination of the forces that give shape to the social division of labour and their links to human invention aimed at discovering new, more efficient ways of doing things, including the design and construction of new machines. Those chapters reveal a clear perception of the coevolution and interdependency of these different spheres of human activity. Modern growth theory, in contrast, offers a highly stylized, aggregate vision of why a given society grows, but unfortunately it is far removed from the systemic coevolution highlighted here.

The growth process involves changes in institutions and technologies as much as changes in economic variables. This is why the process has to be understood as coevolutionary. Although each of these spheres follows its own independent dynamics, the three influence each other as they evolve over time. Trade liberalization lowers the domestic price of capital goods and induces their faster introduction to the economy. But such faster introduction comes hand in hand with the entry of new firms and the introduction of new models of production organization. Institutions, in the sense of habits or patterns of economic behaviour, tend to change as foreign firms enter the economy, which, in turn, modifies the sectoral technological and competitive regimes. A growth theory that does not reflect either this systemic coevolution of economic, technological and institutional factors or the simultaneous working of macro- and microeconomic forces is reductionist and of limited heuristic value. 
In the present Latin American context, individual firms are gradually embracing a new competitive discipline and accepting new market rules. Inward-oriented economies did not induce competitive behaviour on the part of individuals and firms because they were isolated from foreign competition by high tariffs. The gradual assimilation of the new procompetitive regime will undoubtedly take time, as it involves a slow process of learning at the microeconomic level.

In a parallel development, Latin American countries are also going through a complex process of change in their institutional and technological environment. Many institutions, such as intellectual property rights or property rights with respect to natural resources, are presently changing under the pressure of a new worldwide institutional climate. Similarly, production processes are gradually shifting away from an electromechanical foundation towards an electronic, computer-based one involving real-time, continuousflow forms of production organization. Firms along the whole production chain are therefore having to adapt to a new model of production planning and organization.

Although the countries of the region have changed dramatically in each of these spheres over the course of the last two decades, they still lag behind the more developed countries in every one of them. The gap is narrowing, but much remains to be done before the region can achieve world-class production structures, mature institutions prototypical of modern capitalism and local technological capabilities comparable to those of industrialized societies.

The recently implemented structural reforms constitute a valuable step in the right direction, but convergence towards international patterns of social and industrial organization is proving to be much slower and more difficult than initially expected. Such convergence has been characterized by adverse selection, social exclusion and various costs deriving from market failures, asymmetric information and lack of institutions. The recent experience of the so-called countries in transition (i.e., the formerly socialist countries) reveals a similar pattern of adaptation to a new macroeconomic and regulatory regime. Conventional neoclassical thinking holds that opening up to foreign competition, deregulating markets and privatizing economic activities are sufficient conditions for eventually securing a new equilibrium growth path more in line with the "true" opportunity cost of the available resources. It also assumes that what is good for microeconomic efficiency would necessarily be good for equity. The facts simply do not bear out such expectations. Academic economists, international agencies and governments in the region are increasingly inclined to believe that market failures, the lack of institutions and the existence of asymmetries and imperfections in the access to information and factor markets are responsible 
for the less-than-satisfactory overall outcome of the reforms. ${ }^{9}$ They increasingly speak of the need to create markets and institutions that counteract adverse selection and inequitable patterns of access to the benefits of modernization. Many of these issues are addressed in later chapters of this book.

The growth issues examined here involve a number of social and anthropological dimensions that economists are not particularly well equipped to deal with. Economic models are normally institution-free, and they are generally insensitive to the gradual learning process any society goes through in the accumulation of domestic technological capabilities. They are similarly insensitive to the way each particular society undertakes the creation and destruction of social capital. ${ }^{10}$ In sum, received models of economic growth leave a lot to be desired; they are of only limited help in understanding the processes highlighted here.

The countries of the region have achieved a great deal in the 1990s as a result of trade liberalization and market deregulation. Much remains to be achieved, however, if they are to attain faster growth, a better productivity performance and a more equitable distribution of the benefits of the transition to modernity. Only then will it make sense to think of the Latin American countries as developed societies.

9. Illustrative in this regard is the non-orthodox discourse with which Joseph Stiglitz sought to shake World Bank thinking in recent years. Many of his recent arguments have a deeply structuralist tone, which approaches ECLAC's vision of the development process. See Stiglitz (1998a, 1998b).

10. Saxonian (1995) brilliantly examines the question of what it takes to create social capital in any given society and how different the process might be even in two regions of a single country. 


\section{CHAPTER II \\ THE DYNAMICS OF THE INDUSTRIAL RESTRUCTURING PROCESS}

The structural transformation of the Latin American manufacturing sector described in the previous chapter can, for analytical purposes, be divided into two sets of events. The first is related to the restructuring process that takes place within a given manufacturing sector through the entry and exit of firms. The second concerns changes in the inter-industry pattern of production specialization, which occur when particular manufacturing activities gain relative participation within aggregate industrial GDP. These processes take place simultaneously, although the analysis addresses them separately.

\section{A. The Selection Process Among Firms in a Given Industry}

Any given industry comprises firms of very different levels of production efficiency. The age and structure of the capital goods available to different firms and the choice of production organization vary quite significantly, even among close competitors. Consequently, a wide range of unit production costs and profit rates generally coexist within a single field of economic activity at any point in time. In practice, the observed differences are much wider than conventional price theory might lead economists to expect, as such analyses predict a high degree of homogeneity among the various firms in an industry. In effect, if firms are assumed to have perfect information, technology to be a freely accessible good, and factor markets to be competitive and well behaved, then there is little reason to expect a priori that cost might differ significantly 
among firms. In reality, however, the differences are quite sharp. In his pioneering book, G.W.E. Salter (1960) cites British manufacturing data that reveal differences of up to $7: 1$ in the unit production costs of firms that supposedly compete with each other.

Salter's book describes a simple model of an industry's dynamic transformation on the basis of the entry of new firms, which bring in new technology in the form of new products or production processes. If the new technology allows them to produce at lower costs or to introduce a better product, then the market price for the product in question will fall. Marginal firms that cannot cover variable production costs at the new price will be forced out of the market. In Salter's model, firm demography, that is, the pattern of firms entering and exiting an industry, takes a very simple specification. Exogenous technological change allows a new entrant to incur lower production costs and thereby to reduce the market price, putting out of competition those firms with older technologies which cannot cover their variable production costs

In reality, the process of firms entering and exiting the market has been significantly more complex and messy in the region's recent episode of industrial restructuring than that described in Salter's model. Transport costs and tariffs influence the role importers play as potential competitors in domestic markets. Furthermore, factors markets are imperfect, firms have asymmetric information, and they usually command a less-than-perfect understanding of the production technologies with which they operate. Some firms obviously adapt better than others to changes in the macroeconomic policy regime, and these firms gain participation in the market. The remaining firms languish or even exit the market altogether. Initial differences in technological and management capabilities affect the firms' ability to confront major macroeconomic changes, but this is certainly not the only factor at play. The dynamics of sectoral restructuring also involves an important element of randomness, because the adjustment to the new circumstances occurs amid severe macroeconomic turbulence and uncertainty. Because factor markets do not behave adequately, opportunities for adaptation are not perfectly distributed across firms in an industry.

Salter's well-behaved model clearly does not consider these issues. They need to be taken into account, however, to explain why some firms adapted better than others during the recent transition to a new macroeconomic policy regime experienced throughout Latin American manufacturing industries. The available empirical evidence indicates that the firms that managed to survive the period of macroeconomic turbulence often were not the firms that operated the best production facilities or that had most recently invested in upgrading their technology. Rather, firms frequently resorted to speculation and opportunism to survive the recession and macroeconomic turbulence. 
Salter's model is consistent with the three phases of macroeconomic stabilization and structural reform discussed in the previous chapter, as well as with the Schumpeterian notion of creative destruction, which serves as the basis for this analysis of the industrial restructuring process in Latin America. Firms tended to exit the market in the first phase of the adjustment process, whereas most firms that entered the market did so during the third phase of the sequence, after the economy had settled into a more stable and more reliable long-term growth path. Figure II.1 offers a stylized representation of this process, together with its counterpart in terms of productivity growth. The vertical axis measures the industry's average productivity, while the horizontal axis measures the average plant size in the sector. The first distribution of productivities and plant sizes describes what the industry looked like before the structural reforms were actually enforced; the second characterizes the industry after the reforms.

Figure II.1

\section{ENTRY AND EXIT OF FIRMS AND AVERAGE SECTORAL PRODUCTIVITY}

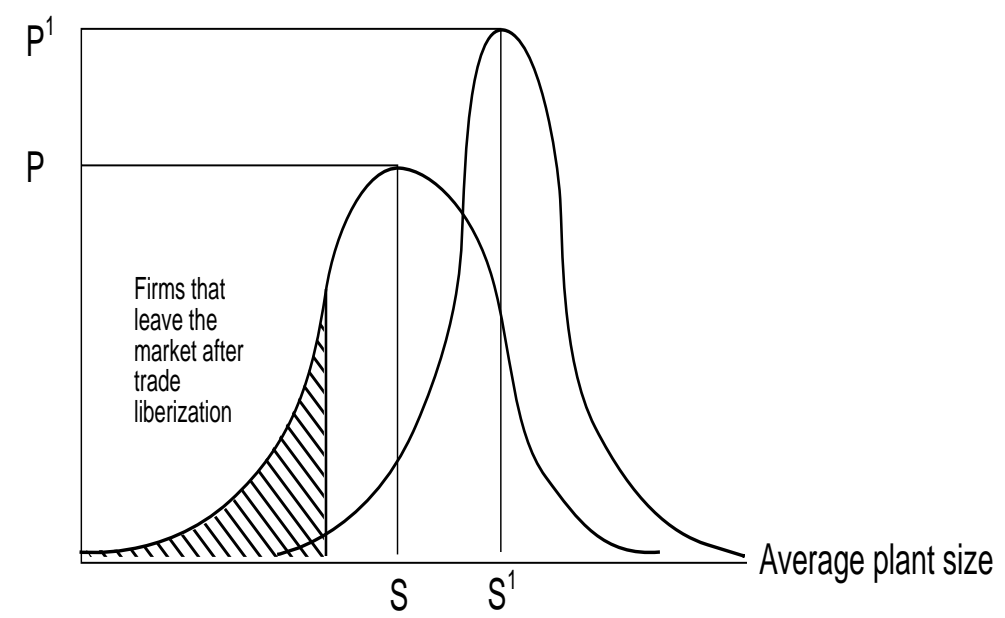

\footnotetext{
$\mathrm{P}$ : Average sectoral productivity before trade liberalization

$\mathrm{P}^{1}$ : Average sectoral productivity after trade liberalization

S: Average size of firm before liberalization

$S^{1}$ : Average size of firm after liberalization
} 
Improvements in productivity come from two sources: (i) the entry into the market of new firms that are bigger and more productive than the existing firms and (ii) the exit of many small firms, presumably the less efficient ones in the industry. What is the relative importance of these two effects? At what point in the structural adjustment cycle do they occur? How do the various branches of manufacturing differ in this regard?

As far as the exit of firms is concerned, Mizala reports that some 7,000 Chilean firms closed down in the mid-1970s and early 1980s, most of them medium sized (see figure II.2). For different reasons, small and large firms found it relatively easier to survive the drastic change in the macroeconomic policy regime that was implemented in Chile following the military coup of 1973 (Mizala, 1992). In Argentina, an estimated 15,000 industrial firms exited the market during the trade liberalization process implemented in the late 1970s. In both cases, the exodus was particularly intense in labour-intensive industries, such as those producing garments, footwear and textiles, as well as in metalworking industries producing capital goods and machine tools. (Katz, 1986).

Figure II.2

\section{CHILE: NUMBER OF INDUSTRIAL FIRMS GOING BANKRUPT, 1975-1993}

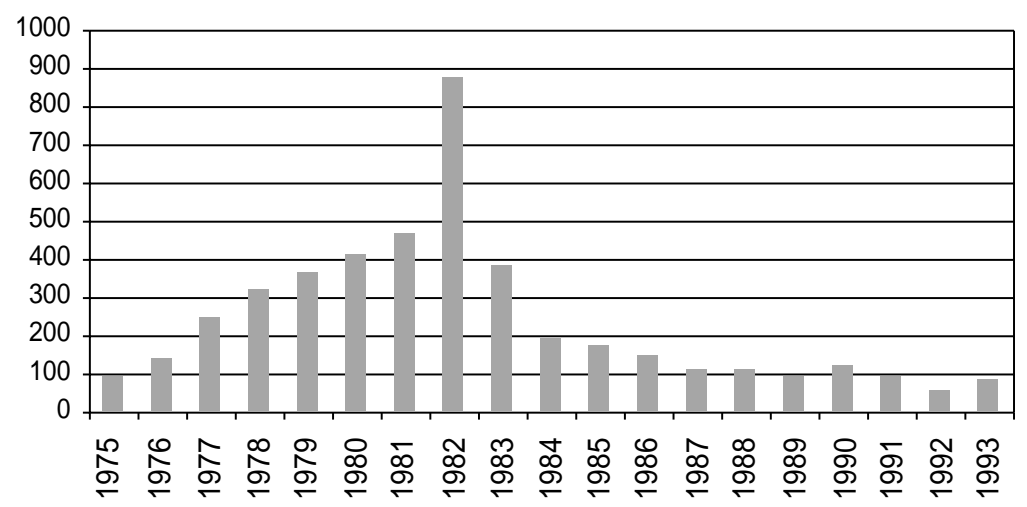

Source: Alejandra Mizala, "Las reformas económicas de los años setenta y la industria manufacturera chilena", Colección estudios CIEPLAN, No. 35, Santiago, Chile, September 1992 (1975-82); Fiscalía Nacional de Quiebras (1983-93). 
Many sectoral studies illustrate the dynamics of this process. In the Argentine steel industry, for example, half of the firms registered by the industry in the early 1970s left the market in the 1980s: the number of firms fell from 59 in 1975 to 26 in 1992 (Azpiazu and Basualdo, 1995). The Chilean footwear industry constitutes another example. The number of firms in the industry fell from 275 in 1979 to 186 in 1982 (Kassai, 2000). In the Argentine vegetable oils industry, the number of firms fell from about 70 in the 1970s to approximately 50 in the early 1990s (Obschatko, 1997). Similar trends occurred in the Argentine and Brazilian pulp and paper sectors (Bercovich, 2000) and the Chilean copper industry (Cáceres, Cárdenas and Katz, 2000). In all of these cases, intra-industry restructuring involved a process of selection among firms and a major transformation of the sector's technological and competitive regime. Business concentration increased in every case, and a certain fraction of the firms approached international productivity standards. Nelson (1997) describes this as an evolutionary process using a biological metaphor, according to which firm "genotypes" and sectoral and national "phenotypes" underlie the restructuring episode.

Turning now to the entry of new firms into the market, fragmentary evidence indicates that this occurs in a context of increasing levels of technology and market concentration. In the case of the Argentine iron and steel industry, for example, two large-scale, state-of-the-art steel mills were set up in the 1990s by Acindar S.A. and Techint S.A. The industry was thus restructured around a new model of industrial organization in which two large domestic conglomerates assumed control of the sector (Azpiazu and Basualdo, 1995). Techint S.A. now operates as a global player on the international seamless tubes market, with nearly one quarter of total world sales.

The Argentine vegetable oils industry is another case at point (see Table II-1). The restructuring of this sector was associated with the entry of a new generation of plants, which not only were bigger in size, but also incorporated a different basic process technology. The industry gradually moved towards catalytic-based production processes, which required a radical change in engineering disciplines and production organization. Furthermore, the industry's technological and institutional infrastructure evolved together. New firms entered the market, and new forms of vertical integration developed between production, transport, dock facilities and overseas shipping (Obschatko, 1996). The privatization of State railways and docks facilities, in particular, paved the way for the forging of new linkages between primary production and downstream processes in the production chain. This clearly indicates that economic, technological and institutional forces were interdependent, and they must be examined together as elements of a single process in the restructuring of the activity as a whole.

In sum, the empirical evidence supports the idea that intra-industry restructuring processes are strongly related to the exit of firms from the market, 
Table II.1

\section{ARGENTINA: FIRMS, EMPLOYMENT AND LABOUR PRODUCTIVITY IN THE ARGENTINE VEGETABLE OIL INDUSTRY, 1973-1974 and 1993-1994}

\begin{tabular}{|c|c|c|c|c|c|}
\hline PERIOd & $\begin{array}{l}\text { NUMBER OF } \\
\text { FIRMS }\end{array}$ & $\begin{array}{l}\text { NUMBER OF } \\
\text { EMPLOYEES }\end{array}$ & $\begin{array}{c}\text { PRODUCTION } \\
\text { VOLUME } \\
\text { (THOUSANDS } \\
\text { OF TONS) } \\
\end{array}$ & $\begin{array}{l}\text { TONS / PLANT } \\
\text { (THOUSANDS) }\end{array}$ & $\begin{array}{c}\text { TONS / EMPLOYEE } \\
\text { (THOUSANDS) }\end{array}$ \\
\hline $1973-1974$ & 67 & 6,895 & 1,740 & 26 & 252 \\
\hline $1993-1994$ & 59 & 4,943 & 12,196 & 207 & 2,472 \\
\hline
\end{tabular}

Source: Edith Obschatko, “Industrialización basada en recursos naturales: El caso del complejo oleaginoso argentino", Buenos Aires, Economic Commission for Latin America and the Caribbean (ECLAC), 1996 (unpublished).

the entry of new state-of-the-art firms and a gradual transformation of the sector's technological and institutional base. Such evidence confirms that restructuring triggers a major transformation in industry's organizational regime, involving the coevolution of economic, technological and institutional forces.

\section{B. Changes in the Relative Share of Industries During the Structural Adjustment Process}

In the last two decades, two quite different models of production specialization have emerged in Latin America, partly, but not entirely, as a result of the recent structural reforms. The first, which is mostly to be found in Argentina, Brazil and Chile, features a strong shift towards natural resourcebased industries that manufacture products such as vegetable oils, pulp and paper, iron and steel, fishmeal, aluminium, orange juice and other commodities. These industries are generally capital intensive and highly automated; they use continuous-flow production processes and relatively little labour.

The second model of production is centred in Mexico and some of the Central American countries, which have specialized in in-bond assembly, or maquila, industries producing computers, televisions, VCRs and garments for export to the United States. These sectors are intensive in their use of low skilled labour. Mexico's maquiladoras generated a dramatically large number of new jobs in the 1990s. They use state-of-the-art, just-in-time technologies, 
with a unit import content as high as $98 \%$ of the total value of shipments. These firms employ total quality techniques, Kanban and sophisticated production logistics, most of which is generated by the international parent firm rather than by the domestic subsidiary itself. They pay a small fraction of the wages prevailing in more developed countries (no more than 10\%), and they are almost exclusively geared to supplying the United States market (Buitelaar et al, 1999).

Suppose the manufacturing sector has only two industries, one producing wage goods of low capital intensity for domestic consumption and the other producing either a raw material-based industrial commodity (say, iron and steel) or a product assembled in a maquiladora (say, computers) for export. Further assume that as a result of the macroeconomic stabilization programme, the domestic market for wage goods undergoes a severe contraction, while the export industry is clearly induced to expand. Following the implementation of the structural reforms, the two industries grow at different rates, as a result of the differential impact of the reforms. The different growth rates reflect not only the impact of the domestic structural reforms, but also the different elasticities of demand of the two goods. It seems reasonable to assume that the elasticity of demand faced by maquiladoras is much higher than that faced by the natural resource-processing industries exporting industrial commodities to world markets. The maquiladoras producing for the United States market are likely to have a higher long-run growth potential than the natural resource-based industries, simply because the international market for industrial commodities grows much more slowly than the market for electronic durables. Both industries feature low domestic value added, but the maquila industry is likely to grow faster, export more and absorb more labour. The natural resource-based industries, in contrast, are likely to grow more slowly and to absorb less labour.

To what extent does the empirical evidence support the above argument? Table II. 2 shows the changes in the region's pattern of production specialization over the last two decades. The data show a clear shift in favour of natural resource-based industries in the South American countries and towards the maquila sector (including the vehicle industry) in Mexico. Specifically, the natural resource-based industries classified by the ISIC as 341, 351, 354, 355, 356, 371 and 372 gained ground in Argentina, Brazil, Chile and Colombia. In Mexico, the automotive sector doubled its relative participation in the country's industrial output. At the same time, the labour-intensive industries producing wage goods for the domestic market lost ground throughout the period in each of the countries under examination.

These results point to a deep-rooted paradox. Market-oriented Washington-consensus economists advised Latin American countries to pursue trade liberalization in order to provoke a dynamic shift in the domestic production structure towards what they perceived to be the region's natural 
Table II.2

\section{CHANGES IN THE RELATIVE WEIGHT OF INDUSTRIAL SECTORS IN TOTAL MANUFACTURING OUTPUT, 1970-1996 (Percentages)}

\begin{tabular}{|c|c|c|c|c|c|c|c|c|c|c|}
\hline \multirow[b]{2}{*}{ SECTOR } & \multicolumn{2}{|c|}{ ARGENTINA } & \multicolumn{2}{|c|}{ BRAZIL } & \multicolumn{2}{|c|}{ Chile } & \multicolumn{2}{|c|}{ Colombia } & \multicolumn{2}{|c|}{ MeXICO } \\
\hline & 1970 & 1996 & 1970 & 1996 & 1970 & 1996 & 1970 & 1996 & 1970 & 1996 \\
\hline I & 15.6 & 13.1 & 18.8 & 22.8 & 14.9 & 10.2 & 10.7 & 10.5 & 13.3 & 13.9 \\
\hline II & 9.9 & 12.1 & 9.9 & 8.7 & 7.7 & 2.0 & 2.9 & 6.5 & 5.5 & 10.8 \\
\hline III+IV & 36.2 & 45.7 & 35.8 & 42.4 & 43.2 & 56.2 & 45.7 & 51.2 & 46.8 & 46.5 \\
\hline V & 38.2 & 29.0 & 35.5 & 26.1 & 34.2 & 31.6 & 40.7 & 31.8 & 34.4 & 28.8 \\
\hline
\end{tabular}

Source: Author's compilation, on the basis of the Programme for the Analysis of Industrial Dynamics (PADI), Economic Commission for Latin America and the Caribbean (ECLAC), Santiago, Chile.

Sector I: Metal-working industry, excluding automobiles (groups 381, 382, 383 and 385 of the International Standard Industrial Classification, or ISIC).

Sector II: Transport equipment (ISIC group 384).

Sector III + sector IV: Foodstuffs, beverages and tobacco (ISIC groups 311, 313 and 314) and natural resource-processing industries (ISIC groups 341, 351, 354, 355, 356, 371 and 372).

Sector V: Labour-intensive traditional industries (ISIC groups 321, 322, 323, 324, 331, 332, 342, $352,361,362,369$ and 390).

comparative advantage, namely, cheap unskilled labour. The Mexican and Central American restructuring process seems to have gone in this direction, but this was not the case in the South American countries. On the contrary, natural resource-based industries producing industrial commodities are strongly capital intensive and computer based, and they employ relatively little labour. In addition, all the countries in the region have lost ground in the labour-intensive industries producing footwear, clothing and furniture as a result of tough competition from countries such as China, the Philippines or Vietnam, where wages are just a fraction of the already very low rates paid by most Latin American countries. The region's labour costs are becoming too high, relatively speaking, for countries to continue to attract investment in maquiladoras, and yet the wages paid in the region are so low that countries cannot develop an attractive domestic market to serve as the foundation for growth in the years ahead.

The two processes examined so far can now be put together to attain an evolutionary picture of the recent restructuring process in Latin American countries. First, the internal structure and performance of industries have changed. Second, the overall pattern of production specialization has gradually been transformed in favour of low value-added maquiladoras and natural resource-based industries. In other words, at the industry level, restructuring 
triggered a process of selection among firms, while at the country level, the overall production fabric has shifted in favour of static comparative advantages.

\section{The Destruction of Human Capital During the Structural Adjustment Process}

The sequence of events described up to this point has an obvious impact on the locally accumulated stock of technological capabilities and engineering skills. Just as old vintages of machinery and equipment are rendered obsolete by the rapid importation of new, computer-based machines, so, too, does human capital lose its relevance in the new production environment, despite having been painfully developed during the ISI decades. Plant engineers who were previously employed to extend the life cycle of the available machines can now be cut from the payroll, since capital equipment can easily be replaced earlier, at a lower cost and embodying computer-based process technologies. Whole research and development $(R \& D)$ and project engineering departments have been eliminated as public firms providing telecommunications, electricity and transportation services have been privatized and transferred to foreignrun public utilities. These and similar developments brought about the "destruction" of human capital and domestic technological capabilities. Some of these capabilities were successfully transferred to other areas of the economy, where they are now being applied to new knowledge intensive activities such as the development of software. The extent to which this has taken place, however, varies widely across nations, regions and industries. Research is simply lacking on these matters to provide the basis for understanding what has actually happened on this front.

Despite the limitations of the available data, these processes present an obvious paradox. Companies, industries and regions are approaching world standards, but they are doing so on the basis of imported, rather than domestic, know-how and technology. Having specialized in activities with a low domestic value added, many Latin American industries are now competing well in the low-value-added extreme of the production chain, and for such purposes, they are using less locally developed or adapted product designs and process technologies. Figure II.3 presents a stylized representation of the argument. It shows that a fall in the relative price of imported substitutes for domestic capital goods induces more utilization of the former (a move from $\mathrm{C}$ to $\mathrm{D}$ in the figure). As a consequence, fewer engineers are needed at the shop-floor level, since their skills had previously been used to extend the life cycle of the available equipment. This second change is represented by a move from B to A in figure II.3. 
Figure II.3

\section{CHEAPER IMPORTED CAPITAL GOODS AND THE CONTRACTION IN THE DEMAND FOR LOCAL HUMAN CAPITAL}

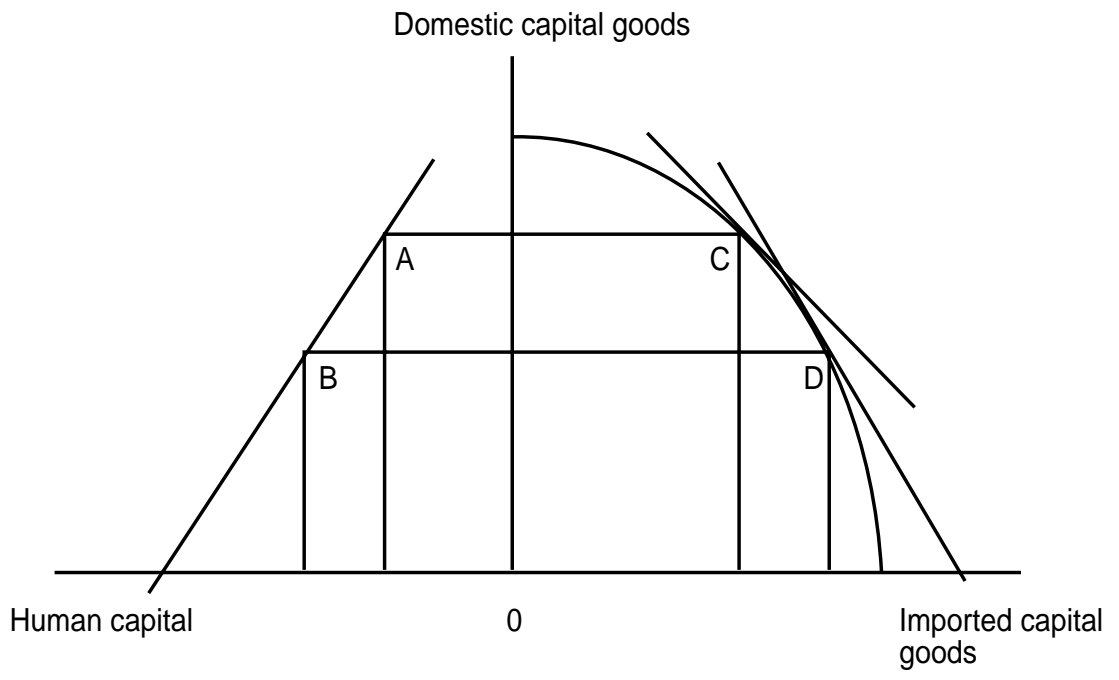

Nonetheless, it can still be argued that the creative phase of the famous Schumpeterian metaphor can be expected to emerge eventually. Very little has been seen so far, however, although as mentioned above, some interesting developments are underway in relation to computer software and services involved in the transition to a knowledge economy. A tiny fraction of local skilled human resources seems to be moving that direction at present.

This concludes the presentation of the conceptual framework of this study. The next section explores the performance of the region's manufacturing and non-manufacturing sectors with regard to labour productivity growth. It also examines the productivity gap that Latin American countries and industries exhibit vis-à-vis the international productivity frontier. Together with the conceptual discussion, the empirical evidence reviewed below offers the reader an overall interpretation of what has happened in Latin America as a result of history, on the one hand, and the recent market-oriented structural reforms, on the other. 
Part Two

STRUCTURAL REFORMS AND ECONOMIC PERFORMANCE: THE EVOLUTION OF LABOUR PRODUCTIVITY 

CHAPTER III

\section{TECHNOLOGICAL CHANGE AND LABOUR PRODUCTIVITY GROWTH IN LATIN AMERICAN MANUFACTURING INDUSTRIES}

Having thus far examined the analytical arguments underlying the present enquiry into the impact of recent structural reforms, the book now turns to the empirical evidence. Are Latin American countries and production activities performing better as a result of these market-oriented reforms? Are there differences across countries or sectors of economic activity in this respect? The discussion centres on the notion of labour productivity growth, as explained in the next section.

\section{A. Labour Productivity as a Proxy for Technical Change}

Technological progress is a crucial force determining the structure and performance of any given society. Despite the importance of innovation for economic growth, the economics profession still lacks a unified, universally accepted theory explaining the variables that stimulate its generation, adaptation, diffusion and utilization in the production of goods and services. As early as 1930, Sir John Hicks made an initial inroad into the subject when he differentiated between autonomous and induced innovation, arguing that the former depends on the dynamics of science and the later on the relative prices of capital and labour. As labour becomes dearer with the passage of time, businesses search for labour saving innovations which would allow them 
to produce at lower costs. On the other hand, in many fields of human knowledge, it is clear that the demand for improved technology exists and that innovation would be handsomely rewarded, but such progress requires prior advances in physics, biology, genetics and other basic sciences, which are lacking.

Until rather recently, technological change was regarded as exogenous to the economic system. When it was treated as endogenous, the analysis tended to be formalistic. Conventional neoclassical models simply fail to capture either the large degree of uncertainty, imperfect understanding and trial and error or the essential element of creative destruction that usually accompany the generation of new technical knowledge

The shortcomings of received theory become even more evident on considering technical progress in the developing world, where not much contribution is ever made to the international technological frontier, but where, nonetheless, a significant amount of knowledge is generated through the adaptation to local circumstances of technical knowledge developed in more advanced industrial societies. Every blueprint, engineering manual or patent has a component that must be developed through trial and error, experimentation and localized research; it cannot simply be plugged in to any and all situations and used as is. Rather, the utilization of knowledge normally involves the generation of additional, incremental units of knowledge that are required to adapt the original idea to the specific circumstances in which it is to be applied. This must be done in situ, so as to make the original blueprint or engineering manual workable under a set of environmental conditions which are different from those that surrounded the original design.

Received theory offers no advice on how to differentiate such adaptive learning efforts, which generate something new -that is, something that was not available before, even if it is only a minor addition to the state of the artand factor substitution, which incorporates something already available in response to changes in relative factor prices. Even in the latter case, however, some amount of adaptation is required for the local utilization of a previously available piece of knowledge, such that technical progress and factor substitution along a given production function become almost inseparable from one another. As Salter notes, a change in a given production function obviously entails a virtually inseparable mix of factor substitution (in response to changes in relative prices) and technical progress (i.e., movements of the production function outwards, spurred by genuinely new technological knowledge). While the former force is closely linked to the spread of available technologies in society, the latter reflects the search for new ways of doing things, new products or new productive processes. The two forces are inextricably linked, however, and are thus difficult to isolate in practice (Salter, 1960).

Technical change can be measured indirectly by following the flow of inputs required for its generation (e.g., R\&D expenditure, investment in pilot 
plants or experimental equipment) or it can be measured directly using a proxy for its impact (e.g., number of new products, number of patents or simply the rate of productivity growth attained by a region, industry or firm) (Freeman, 1974; Schmookler, 1966; Pavitt, 1984; Terleckij, 1959). This chapter uses labour productivity growth and the labour productivity gap with the United States manufacturing sector as proxy variables for technical progress. The central purpose of the analysis is to examine how the rate of labour productivity growth behaved before and after the recent structural reforms and whether Latin American countries and industries are catching up or lagging behind the world's outward-moving productivity frontier.

\section{B. Labour Productivity in the Latin American Manufacturing Sector Before and After Recent Structural Reforms}

This section estimates labour productivity growth for the industrial sector of various Latin American countries and individual industries at the threedigit level of aggregation of the International Standard Industrial Classification (ISIC). The aggregate analysis of the manufacturing sector is based on nine countries, while the analysis of specific industries draws on five countries, namely, Argentina, Brazil, Chile, Colombia and Mexico. The chapter uses the PADI database (Programme for the Analysis of Industrial Dynamics), which was recently compiled by ECLAC's Division of Production, Productivity and Management. PADI provides information on value added, employment, wages, labour productivity (measured as value added per capita per year), unit labour costs and gross unit margins for the period 1970-1996. The data make it possible to compare countries in the region with each other and also with the United States.

Table III.1 presents the labour productivity indicators for the manufacturing sector as a whole for nine countries in the region plus the United States. The indicators are calculated for the period 1970-1996 and for the 1990s separately. Note that the 1990s demonstrate a significant acceleration in the labour productivity growth rate in most Latin American countries and also in the United States.

For the longer period, 1970-1996, four countries in the region (Argentina, Colombia, Mexico and Brazil) managed to attain a rate of labour productivity growth in manufacturing production that was higher than that of the United States. This implies that although the productivity gap between these three countries and the United States is still large in absolute terms, in relative terms it is getting smaller.

Table III.2 breaks down labour productivity growth by decade, using the United States as a benchmark. The table shows that Argentine industry 
Table III.1

\section{GROWTH OF INDUSTRIAL OUTPUT, EMPLOYMENT AND LABOUR PRODUCTIVITY IN LATIN AMERICAN MANUFACTURING AND IN THE UNITED STATES, 1970-1996 (\%)}

\begin{tabular}{|c|c|c|c|c|c|c|}
\hline \multirow[b]{2}{*}{ COUNTRY } & \multicolumn{2}{|c|}{ INDUSTRIAL OUTPUT } & \multicolumn{2}{|c|}{ EMPLOYMENT } & \multicolumn{2}{|c|}{ LABOUR PRODUCTIVITY } \\
\hline & 1970-1996 & $1990-1996$ & 1970-1996 & $1990-1996$ & $1970-1996$ & $1990-1996$ \\
\hline Argentina & 1.18 & 4.87 & -2.62 & -3.15 & 3.80 & 8.02 \\
\hline Brazil & 2.81 & 2.26 & 0.95 & -6.41 & 1.86 & 8.67 \\
\hline Chile $^{a}$ & 2.76 & 6.40 & 1.51 & 3.49 & 1.25 & 2.91 \\
\hline Colombia & 3.98 & 3.52 & 1.24 & -0.22 & 2.74 & 3.74 \\
\hline Costa Ricab & 4.39 & n.a. & 4.83 & n.a. & -0.44 & n.a \\
\hline Jamaicab $^{b}$ & 0.11 & n.a. & 1.66 & n.a. & -1.55 & n.a \\
\hline Mexico $^{c}$ & 3.79 & 2.27 & 0.91 & -0.03 & 2.88 & 2.30 \\
\hline Peru & 1.17 & 5.09 & 2.85 & 1.97 & -1.68 & 3.12 \\
\hline Uruguaya $^{a}$ & 0.61 & -1.46 & 0.37 & -8.58 & 0.24 & 7.12 \\
\hline United States & 2.39 & 5.04 & 0.35 & 0.30 & 2.04 & 4.74 \\
\hline
\end{tabular}

Source: Calculated on the basis of the Programme for the Analysis of Industrial Dynamics (PADI), Economic Commission for Latin America and the Caribbean (ECLAC), Santiago, Chile.
a/ Data up to 1995.
b/ Data up to 1992.
c/ Data up to 1994.

Table III.2

INDUSTRIAL LABOUR PRODUCTIVITY VIS-À-VIS THE UNITED STATES MANUFACTURING SECTOR, 1970-1996

(United States $=1.00$ in 1970)

\begin{tabular}{lcccc}
\hline CountRY & 1970 & 1980 & 1990 & 1996 \\
\hline Argentina & 0.42 & 0.41 & 0.55 & 0.67 \\
Brazil & 0.28 & 0.26 & 0.29 & 0.37 \\
Chile $^{\mathrm{a}}$ & 0.25 & 0.24 & 0.23 & 0.20 \\
Colombia $_{\text {Costa Rica }}$ & 0.29 & 0.25 & 0.37 & 0.34 \\
Jamaica $^{\mathrm{b}}$ & n.a. & n.a. & 0.15 & 0.14 \\
Mexico $^{c}$ & 0.26 & 0.16 & 0.16 & 0.13 \\
Peru $_{\text {Uruguay }}^{\mathrm{a}}$ & 0.32 & 0.30 & 0.44 & 0.38 \\
l $^{\text {Source: }}$ & 0.33 & 0.25 & 0.16 & 0.15 \\
& 0.35 & 0.22 & 0.20 & 0.22 \\
\hline
\end{tabular}

Source: Calculated on the basis of the Programme for the Analysis of Industrial Dynamics (PADI), Economic Commission for Latin America and the Caribbean (ECLAC), Santiago, Chile.
a/ Data up to 1995.
b/ Data up to 1992.
c/ Data up to 1994. 
began the 1970 s at just over $40 \%$ of United States industrial labour productivity in manufacturing; it ended the period under consideration at nearly double that initial level, reaching close to $70 \%$ of the United States rate. Colombia and Mexico also attained improvements, although smaller than Argentina. Brazil was basically stagnant in 1970-1990 but then achieved very significant labour productivity improvements in 1990-1996, which allowed it to partially close the productivity gap with the United States by 1996. In contrast to these four cases, Chile and Costa Rica maintained a fairly constant relative labour productivity gap with the United States, while the gap tended to increase in Jamaica, Peru and Uruguay. Chile is interesting in that despite having doubled its labour productivity growth rate in manufacturing after the implementation of structural reforms, it ended the period with slight decline vis-à-vis its position in 1970.

Returning to the countries that partially closed the relative labour productivity gap with the United States, practically all of the narrowing of the gap attained by Colombia and Mexico took place during the period 19701990, and their relative performance then deteriorated somewhat in the first part of the 1990s. In the case of Argentina, about half of the relative improvement vis-à-vis the United States took place between 1970 and 1990, and the other half occurred during the 1990s. In other words, in all three cases, an important part of the closing of the labour productivity gap with the United States occurred before those countries fully embarked on structural reform. ${ }^{11}$ Brazil is different in that the closing down of the gap occurs in the 1990s.

Using the rate of labour productivity growth vis-à-vis the international productivity frontier as a reasonable proxy for technological change thus demonstrates that the ISI period contributed significantly to the relative catching up or lagging behind of these economies; the recent structural reforms do not explain the lion share of what seems to be happening on this front. Argentina, Colombia and Mexico were closing the relative labour productivity gap before the structural reforms of the 1990s. The long-term relative performance of Colombia and Mexico actually deteriorated in the first half of the 1990s. On the other hand, both countries demonstrated very significant productivity improvements in 1998-2000, but unfortunately these two years are still too recent to be included in the database and thus could not be made

11. It should be recalled that the liberalization and deregulation of the region's economies did not begin in the 1990s. Argentina, for example, made steady progress in that direction in 1976, under the administration of Minister Martínez de Hoz. Import tariffs were cut, price controls were eliminated, and similar measures were adopted. Although the liberalization and deregulation failed in 1981, signs of the restructuring of the productive apparatus were evident long before the 1990s. The same can be said of Colombia and Mexico. See Katz and Kosacoff (1989). What happened in the 1980s as regards the relative labour productivity gap with the United States, however, owed less to the fact that the countries of the region enjoyed significant productivity improvements than to the fact that the United States performed particularly poorly. See Benavente and others (1997). 
part of the analysis here. Argentina continued to narrow the relative labour productivity gap in the first half of the 1990s, much as it had done in the 19701990 period, but it stagnated in the late 1990s (which is similarly not reflected in the data). ${ }^{12}$

In none of the other cases did the relative labour productivity gap in manufacturing shrink in the 1990s, despite the significant increase in the growth rate of per capita output experienced by most countries in the region. Because the United States also attained a very significant improvement in its long term labour productivity growth rate, the net balance can be positive or negative depending on the particular case examined. Chile and Costa Rica exhibit no relative improvement on this front, while Jamaica and Peru clearly worsened in relative terms.

\section{Labour Productivity Growth at the Individual Industry Level}

This section examines labour productivity growth vis-à-vis the United States at the individual industry level for 27 sectors in five Latin American countries, namely, Argentina, Brazil, Chile, Colombia and Mexico. Table III.3 presents the results. A coefficient greater than 1 indicates that between 1970 and 1996, that particular industry tended to close the labour productivity gap with its United States counterpart, while a coefficient of less than 1 means that the gap increased. The table shows great heterogeneity across industries within a given country, as well as large intra-industry differences across countries.

Between 1970 and 1996, 22 out of 26 industries in Argentina narrowed their relative labour productivity gap with the United States counterpart. ${ }^{13}$ Six did so significantly, having doubled their relative position when compared to the base year (1970). This appears in the table as a coefficient equal to or greater than 2. In Brazil, 21 industries closed the relative labour productivity gap during the same period, though only three did so significantly. In Colombia, 17 industries tended to close the gap, five significantly. In Mexico, as well, 17 closed the gap, four significantly. Finally, only 12 industries in Chile tended to close the labour productivity gap with the United States. The data thus indicate a very heterogeneous inter-industry pattern of responses. The industry data confirm the aggregate result, showing a relatively better

12. With regard to the region's relative success in the first half of the 1990s and relative failure in the second half, and how this is related to the workings of international capital markets, see ECLAC (2000).

13. The data for sector 353 (oil refining) are not reliable and thus are omitted from this analysis. 
Table III.3

RELATIVE LABOUR PRODUCTIVITY GAP IN MANUFACTURING VIS-À-VIS THE UNITED STATES, 1970-1996a (United States $=1.00$ )

\begin{tabular}{|c|c|c|c|c|c|c|}
\hline & ISIC GROUPb & ARgENTINA & BRAZIL & $\mathrm{CHILE}^{\mathrm{C}}$ & ColomBIA & MeXICO \\
\hline 311 & Foodstuffs & 1.10 & 1.14 & 0.67 & 0.93 & 1.21 \\
\hline 313 & Beverages & 1.04 & 0.72 & 0.91 & 0.79 & 0.83 \\
\hline 314 & Tobacco & 0.74 & 0.21 & 0.76 & 0.28 & 0.38 \\
\hline 321 & Textiles & 1.67 & 1.43 & 0.77 & 1.23 & 0.75 \\
\hline 322 & Clothing & 1.17 & 1.20 & 0.75 & 1.30 & 1.85 \\
\hline 323 & Leather products & 1.38 & 0.93 & 0.45 & 0.58 & 0.97 \\
\hline 324 & Footwear & 0.78 & 1.13 & 0.65 & 1.03 & 0.72 \\
\hline 331 & Wood & 0.55 & 0.87 & 0.97 & 0.94 & 0.94 \\
\hline 332 & Furniture & 2.69 & 1.40 & 1.13 & 0.85 & 0.96 \\
\hline 341 & Paper and cellulose & 0.99 & 1.26 & 1.10 & 1.12 & 1.03 \\
\hline 342 & Printing and publications & 1.21 & 0.86 & 1.43 & 0.89 & 1.03 \\
\hline 351 & Chemical industry & 1.92 & 1.18 & 1.79 & 1.09 & 0.88 \\
\hline 352 & Other chemicals & 1.98 & 0.60 & 0.97 & 0.86 & 0.58 \\
\hline 353 & Oil refining & 1.22 & 1.57 & 3.35 & 0.28 & 0.30 \\
\hline 354 & Coal products & 1.85 & 2.07 & 2.14 & 2.10 & 1.55 \\
\hline 355 & Rubber products & 1.55 & 2.55 & 0.41 & 1.36 & 1.24 \\
\hline 356 & Plastic products & 0.81 & 1.25 & 0.51 & 1.50 & 1.25 \\
\hline 361 & Ceramics & 1.33 & 1.20 & 0.45 & 2.24 & 2.47 \\
\hline 362 & Glass & 1.91 & 1.92 & 1.67 & 1.57 & 1.60 \\
\hline 369 & Metallic & 2.35 & 1.28 & 1.68 & 1.36 & 1.39 \\
\hline 371 & Iron & 2.54 & 1.97 & 1.33 & 2.82 & 1.54 \\
\hline 372 & Non-ferrous metals & 1.28 & 2.50 & 0.43 & 1.92 & 2.39 \\
\hline 381 & Metal products & 2.07 & 1.78 & 1.22 & 1.79 & 1.39 \\
\hline 382 & Non-electrical machinery & 1.91 & 1.12 & 1.31 & 0.75 & 0.72 \\
\hline 383 & Electrical machinery & 2.68 & 1.97 & 0.94 & 0.99 & 1.76 \\
\hline 384 & Transport equipment & 2.00 & 1.33 & 0.76 & 2.07 & 1.81 \\
\hline \multirow[t]{2}{*}{385} & Professional scientific & & & & & \\
\hline & instruments & 1.29 & 1.48 & 1.22 & 3.27 & 3.81 \\
\hline 390 & Other manufactures & 0.52 & 0.76 & 0.92 & 1.26 & 2.19 \\
\hline
\end{tabular}

Source: Calculated on the basis of the Programme for the Analysis of Industrial Dynamics (PADI), Economic Commission for Latin America and the Caribbean (ECLAC), Santiago, Chile.
a/ The figures in boldface identify industries that are rapidly catching up.
b/ International Standard Industrial Classification.
c/ 1970-1995.
d/ 1970-1994. 
performance in Argentina, followed by Brazil, Mexico and Colombia. Chile performed the worst of the five in terms of converging with United States manufacturing labour productivity.

Table III.4 reports the inter-industry coefficient of dispersion around the average rate of convergence. The coefficient is smaller in Argentina and Brazil than in the other three countries, reflecting the fact that the closing up of the relative labour productivity gap tended to be a more generalized phenomena (i.e., more widespread across industries) than in the other economies. Chile again stands out with greater structural heterogeneity in its inter-industry responses. If anything, this structural heterogeneity increased through time. In the other four cases, the dispersion coefficient fell in the 1990s, which indicates that the faster labour productivity growth of this decade was more evenly distributed across the industrial spectrum.

Table III.4

INTER-INDUSTRY RATE OF DISPERSION IN THE RELATIVE PRODUCTIVITY GAP, 1970-1996

\begin{tabular}{lcc}
\hline CounTRY & $1970-1996$ & $1990-1996$ \\
\hline Argentina & 0.412 & 0.389 \\
Brazil & 0.408 & 0.303 \\
Chile $^{\mathrm{a}}$ & 0.572 & 0.594 \\
Colombia $^{\text {Mexico }}$ & 0.528 & 0.435 \\
\hline
\end{tabular}

Source: Calculated on the basis of the Programme for the Analysis of Industrial Dynamics (PADI), Economic Commission for Latin America and the Caribbean (ECLAC), Santiago, Chile.

a/ Data through 1995.

b/ Data through 1994.

\section{The Acceleration of Labour Productivity Growth in the 1990s and the Impact of the Structural Reforms}

One of the stated purposes of the present enquiry was to obtain some measure of the impact of the recent structural reforms on productivity growth and on the technological gap between Latin American countries (and individual industries) and the international productivity frontier. Did the reforms alter sectoral trends with regard to labour productivity growth visà-vis the United States? The first step towards answering this question is 
estimating the relative labour productivity growth rate of the various industries in the countries under consideration, vis-à-vis their counterpart in the United States, over the period 1970-1990. The exercise provides the basis for analysing the evolution of relative labour productivity growth in the 1990s.

As shown earlier, all of the countries except Mexico managed to grow faster in terms of industrial labour productivity in the 1990s than in the two earlier decades. This also happened in the United States, however, so having grown faster in the 1990s was not necessarily a sufficient condition for closing the relative productivity gap with United States manufacturing production. For that to have occurred, they would have had to grow even faster than the rapidly growing United States manufacturing sector. Was this the case? The results vary by country. Mexico's labour productivity growth was slower in the first half of the 1990s, causing the relative gap with the United States to increase compared to its relative performance in the previous two decades. Colombia, Chile and Peru all experienced faster labour productivity growth in the 1990s than in the two previous decades, but they did not grow faster than the United States manufacturing sector. Consequently, they show no relative improvement (and even a marginal decline in the case of Colombia) vis-à-vis their performance in the 1970-1990 period. Argentina, Brazil and Uruguay posted a faster rate of labour productivity growth than the United States in the 1990s, thereby closing the gap with the evolving frontier. Only in the case of Argentina does this appear to be the continuation of a long-term trend that was already present in the previous two decades. In Brazil and Uruguay, the 1990s represent a significant discontinuity with the 1970-1990 period, in which the relative situation improved very modestly (Brazil) or deteriorated (Uruguay).

Table III.5 presents estimates of what happened in terms of relative labour productivity growth during the period 1970-1990 for 27 industries in the five countries under consideration. The data are equivalent to those presented earlier in table III.3, but they cover the two decades preceding the structural reforms of the 1990s, whereas table III.3 covers the entire 1970-1996 period. A coefficient greater than 1 indicates that the industry in question was converging with the United States in terms of labour productivity during these two decades, while a coefficient of less than 1 indicates that it was falling behind this benchmark.

A significant number of industries were already narrowing the labour productivity gap with the United States prior to the structural reforms of the 1990s. This was the case in 16 out of 27 industries in Argentina and Brazil, 17 in Chile, 23 in Mexico and 24 in Colombia. This evidence indicates that the pro-market reforms do not fully explain the recent trend towards convergence with the international productivity growth frontier shown by particular industries. The structural reforms have accelerated the pace, but they did not trigger the process, which in many cases was already underway in previous 
Table III.5

\section{RELATIVE LABOUR PRODUCTIVITY GAP VIS-À-VIS THE UNITED STATES INDUSTRIAL SECTOR, FOR LATIN AMERICAN \\ INDUSTRIES, 1970-1990 \\ (United States $=1.00$ )}

\begin{tabular}{|c|c|c|c|c|c|c|}
\hline & ISIC GROUP ${ }^{a}$ & Argentina & BRAZIL & ChILE & Colombia & MeXICO \\
\hline 311 & Foodstuffs & 0.96 & 0.91 & 0.72 & 1.19 & 1.34 \\
\hline 313 & Beverages & 0.87 & 0.78 & 0.89 & 0.94 & 1.14 \\
\hline 314 & Tobacco & 0.72 & 0.36 & 1.41 & 1.11 & 0.69 \\
\hline 321 & Textiles & 1.40 & 1.48 & 0.85 & 1.48 & 1.01 \\
\hline 322 & Clothing & 0.80 & 1.06 & 0.80 & 1.01 & 2.44 \\
\hline 323 & Leather products & 0.78 & 1.17 & 1.12 & 1.06 & 2.20 \\
\hline 324 & Footwear & 0.62 & 1.0 & 0.65 & 1.63 & 0.93 \\
\hline 331 & Wood & 0.57 & 0.65 & 1.45 & 1.39 & 1.29 \\
\hline 332 & Furniture & 1.88 & 1.0 & 1.00 & 0.89 & 1.12 \\
\hline 341 & Paper and cellulose & 0.85 & 1.20 & 1.61 & 1.50 & 1.40 \\
\hline \multirow[t]{2}{*}{342} & Printing and & & & & & \\
\hline & publications & 1.09 & 0.74 & 1.27 & 1.08 & 1.35 \\
\hline 351 & Chemical industry & 1.78 & 1.12 & 3.10 & 1.42 & 1.16 \\
\hline 352 & Other chemicals & 1.80 & 0.70 & 1.15 & 1.01 & 0.79 \\
\hline 353 & Oil refining & 0.60 & 1.44 & 3.56 & 0.36 & 0.41 \\
\hline 354 & Coal products & 1.29 & 1.80 & 1.47 & 2.84 & 2.00 \\
\hline 355 & Rubber products & 1.00 & 0.95 & 0.66 & 1.39 & 1.21 \\
\hline 356 & Plastic products & 0.60 & 0.86 & 0.73 & 1.40 & 1.45 \\
\hline 361 & Ceramics & 0.65 & 0.80 & 0.25 & 1.96 & 2.45 \\
\hline 362 & Glass & 1.52 & 1.37 & 2.10 & 1.69 & 1.68 \\
\hline 369 & Metallic & 1.19 & 0.85 & 1.50 & 1.69 & 1.69 \\
\hline 371 & Iron & 1.70 & 1.42 & 1.30 & 3.34 & 2.17 \\
\hline 372 & Non-ferrous metals & 1.15 & 1.53 & 0.68 & 2.10 & 2.37 \\
\hline 381 & Metal products & 1.75 & 1.08 & 1.14 & 1.28 & 1.40 \\
\hline \multirow[t]{2}{*}{382} & Non-electrical & & & & & \\
\hline & machinery & 1.47 & 1.03 & 1.00 & 0.79 & 0.74 \\
\hline 383 & Electrical machinery & 1.79 & 1.14 & 1.00 & 1.20 & 1.82 \\
\hline 384 & Transport equipment & 1.01 & 0.83 & 1.00 & 1.44 & 1.81 \\
\hline \multirow[t]{2}{*}{385} & Professional scientific & & & & & \\
\hline & instruments & 1.78 & 1.46 & 0.81 & 2.76 & 4.35 \\
\hline 390 & Other manufactures & 0.76 & 0.86 & 0.66 & 1.47 & 2.39 \\
\hline
\end{tabular}

Source: Calculated on the basis of the Programme for the Analysis of Industrial Dynamics (PADI), Economic Commission for Latin America and the Caribbean (ECLAC), Santiago, Chile.

a/ International Standard Industrial Classification. 
decades. Comparing the results of tables III. 3 and III.5 shows that of the 22 (out of 27) industrial sectors that narrowed the relative labour productivity gap in Argentina vis-à-vis the United States between 1970 and 1996, 16 were already doing so during the ISI period. The reforms appear to be associated with significant improvements in the relative performance of sectors like leather products, ceramics, non-metallic minerals, transport equipment, and iron and steel, but in many other industries the relative gap was already closing well before the structural reforms of the 1990s.

Of the 21 Brazilian industries that managed to narrow the relative labour productivity gap with the United States between 1970 and 1996, 15 were already doing so in the previous two decades. Prominent among the sectors that improved their relative performance after trade liberalization were transport equipment, non-metallic minerals, non-ferrous metals, wood products, and iron and steel.

In the case of Chile, of the 13 industries that closed the relative labour productivity gap with the United States in the period 1970-1996, 12 were already doing so during the period 1970-1990. The industries that improved their long-term relative productivity in the 1990s include printing and publishing, ceramics, non-metallic minerals and non-electrical machinery.

In sum, the data prompt the following conclusions:

(i) Some countries of the region, particularly Argentina, Colombia, Mexico and Brazil, were relatively more successful than others in closing the labour productivity gap with the United States. By contrast, the relative performance of Chile and Costa Rica was fairly stable, while Jamaica, Peru and Uruguay suffered relative deterioration.

(ii) Labour productivity improvements and the closing of the gap with the United States reveal a high degree of heterogeneity among industries and countries.

(iii) The growth rate of labour productivity clearly increased in the 1990s in most of the Latin American countries, but this also happened in the United States.

(iv) Consequently, Latin America's improved performance with regard to labour productivity growth in the 1990s does not necessarily translate into a closing of the relative gap with the United States.

(v) The narrowing of the labour productivity gap with the United States was already taking place in many countries and industries prior to the structural reforms of the 1990s.

(vi) As a result of the recent reform efforts, some new industries joined the group of successful industries that were already closing the labour productivity gap with their United States counterparts. The specific industries varied across countries, but the groups were similar in Argentina and Brazil, on the one hand, and Colombia and Mexico, on the other.

(vii) The data do not support the conclusion that trade liberalization and market deregulation efforts were a necessary and sufficient condition for 
successfully converging with labour productivity standards in the United States. Structural reforms undoubtedly increased competitive pressure, and this was important for boosting the growth rate of labour productivity. The empirical evidence shows, however, that segments of the region's manufacturing sector were already converging with international patterns of efficiency well before the onset of the structural reforms. The reforms accelerated the process, but they did not trigger it amid generalized failure.

\section{E. Why Some Industries Catch Up While Others Fall Behind in the Process of Economic Growth}

The data presented in the preceding sections help identify which industries have done well and are gradually converging with the international productivity frontier and which are falling behind international standards. They do not, however, explain why this is happening.

In principle, at least two different, but complementary, explanations might apply. The first highlights domestic circumstances, whereas the second stresses the role of external factors. Given that the phenomenon in question is the relative productivity performance vis-à-vis the international productivity frontier, either a rapid expansion of domestic labour productivity or a slow outward movement of the frontier could cause an improvement in the relative performance. The literature on growth identifies a deceleration in the productivity growth rate of the United States between the mid-1970s and the mid-1980s; this opened the possibility for Latin American countries and industries to converge with the United States during that period even without significant improvements of their own in labour productivity.

Similarly, a successful domestic performance in a particular industry could be the result of macroeconomic variables (e.g., aggregate demand growing at a rather fast pace) or, alternatively, it could be a consequence of sectoral variables that affect one specific field of economic activity, but not others (e.g., special legislation affecting the automobile industry). The policy signals given to a particular economic activity can spur a rapid process of investment and growth beyond what is happening in the economy at large.

This brief discussion demonstrates how the explanation of why countries and industries catch up or fall behind is far more complex than can be addressed here. A sector-by-sector examination of the local and external reasons for the narrowing or widening of the gap between specific industries and the international benchmark is obviously beyond the scope of this book. Preliminary evidence indicates, however, that macroeconomic forces, represented by the overall growth rate of the economy, do matter as explanatory variables in the success or failure of most industries in the convergence process. In principle, we could expect convergence to be easier wherever aggregate 
demand is expanding rapidly. Success breeds success, as development economists often suggest. This is supported by the cross-section estimates presented in table III.6, in which the industry's growth rate throughout the period 1970-1996 is used as an independent variable to explain changes in the relative labour productivity gap with United States manufacturing.

Table III.6

CROSS-SECTION REGRESSIONS BETWEEN INDUSTRY GROWTH AND CHANGES IN THE LABOUR PRODUCTIVITY GAP VIS-À-VIS UNITED STATES MANUFACTURING, 1970-1996

\begin{tabular}{lcccrc}
\hline CountRy & $\begin{array}{c}\text { Regression } \\
\text { COEFFICIENT }\end{array}$ & Standard ERROR & $R^{2}$ & F Statistic & $\begin{array}{c}\text { DeGREes } \\
\text { OF FREEDOM }\end{array}$ \\
\hline Argentina & 0.77 & 0.13 & .59 & 33.56 & 23 \\
Brazil & 1.13 & 0.06 & .95 & 419.05 & 22 \\
Chile & 0.68 & 0.14 & .55 & 22.39 & 20 \\
Colombia & 0.89 & 0.25 & .33 & 12.59 & 25 \\
Mexico & 1.17 & 0.21 & .57 & 31.97 & 24 \\
\hline
\end{tabular}

Source: Calculated on the basis of the Programme for the Analysis of Industrial Dynamics (PADI), Economic Commission for Latin America and the Caribbean (ECLAC), Santiago, Chile.

Leaving aside the case of Colombia, for which our statistical results are rather poor, the regression coefficients seem to confirm the hypothesis that the overall growth rate of the economy has a significant impact on the performance of the industrial sectors. Within an expanding global environment the industries that grow faster open up more opportunities for new investment and productivity growth. By contrast, slow growing industries are likely to foster defensive business practices and fewer opportunities for productivity improvement. This cursory analysis obviously needs to be complemented by other macroeconomic as well as sector-specific variables, describing both the domestic and foreign situation of each specific industry, to more fully explain why particular industries catch up or fall behind in the long-term process of economic growth. 


\section{F. Sectoral Competitive and Technological Regimes ${ }^{14}$}

The restructuring process that each particular industry has gone through over the course of the last two decades -which is partly explained, as already seen, by long-term historical trends in industrial organization and partly by the response of firms in that industry to changes in the macroeconomic policy regime-assumes a highly idiosyncratic pattern, one that differs across sectors and countries. This pattern is termed the sectoral competitive and technological regime. As a result of both historical trends and the recent structural reforms, a large number of industries in the region are undergoing a major transformation in their competitive and technological regime, moving outwards to an entirely new model of structure and behaviour. Tariff and non-tariff barriers to competition have fallen; the age and modernity of production facilities have improved; product designs have been brought closer to international standards; production organization has become less vertical; industries have become more concentrated; and the degree of foreign participation has increased at the expense of SMEs and large domestic conglomerates. The sum of all these processes constitutes a major change in an industry's competitive and technological regime.

Industries clearly demonstrate sharp differences in the extent to which these changes have already taken place. In some cases, the process is very advanced or even finished; in others, it is currently in the middle of the transition period. Economists have made little progress to date in understanding these processes of structural transformation. They can thus offer little guidance on how micro- and macroeconomic forces (i.e., technological, economic and institutional) shape the long-term structural transformation of a sector.

Take, for example, the recent structural transformation of the iron and steel industry (ISIC group 371 in the previous tables). Argentina, Brazil and Colombia exhibit a remarkable convergence with labour productivity in the United States, while Chile and Mexico show moderate success. In other words, all five countries improved their relative labour productivity position vis-àvis the United States in the period under study. What explains this outcome? The weak technological performance of the United States iron and steel industry is clearly part of the explanation. This is well documented in the

14. A series of recent studies, including those by the Italian economist Franco Malerba, stress sectoral systems of innovation and production as an explanatory framework for the varying growth performances of different productive activities. Such authors argue that the base of technical knowledge differs by sector, as do institutions and direct and indirect forms of interaction among particular firms. This triggers extremely heterogeneous dynamics of sectoral development. The idea is very close to the argument presented here. See Malerba (1997). 
literature and does not need much discussion here. Basically, steel mills in the United States experienced major difficulties in adopting process innovations that had already been implemented in the European, Korean and other iron and steel industries. This does not wholly explain what happened in Latin America, however. Consider the case of Argentina. As mentioned in chapter II, the Argentine steel industry underwent deep structural changes in the 1980s and 1990s, including the privatization of Somisa, a large public firm. Many SMEs left the steel market or were taken over by either Techint S.A. or Acindar S.A., the two largest domestic conglomerates in this field. In 1975, the sector had 59 industrial plants; at the start of the 1990s, it only had 26. When the State plant was privatized, it was acquired by Techint S.A., which also purchased the Mexican firm TAMSA and Venezuela's SIDOR, as well as forging strategic alliances with large European groups through which it acquired control of Italian iron and steel mills. In other words, Techint S.A. repositioned itself as a world player in the international arena, despite the sharp decline Argentina experimented in aggregate investment rates throughout the 1980s. The company is now a global actor, with diversified businesses throughout the world in iron and steel and in the production of seamless tubing. The microeconomic and sector-specific factors underlying the behaviour of this firm hold important clues to what industrial organization is all about and how it relates to growth theory generally. Macro-, meso- and microeconomic forces of a technological, institutional and economic nature have all clearly played a role, and their interdependence requires further examination.

The restructuring of the Argentine iron and steel industry is a clear case of a rapidly changing competitive and technological regime, featuring the exit and entry of firms; the adoption of new technologies by surviving firms; falling tariff protection; foreign direct investment by large domestic conglomerates; an increasing rate of business concentration; a dramatic change in sectoral institutions; and shifting microeconomic patterns of conduct in response to government actions. A new competitive and technological regime now governs the process of capital accumulation and surplus appropriation within the sector, which must be taken into account in analysing the longterm growth path of this industry.

A similar analysis could be carried out for a number of Brazilian, Chilean, Colombian or Mexican industries. In many cases, this process actually started in the late 1970s and early 1980s and then accelerated in response to changes in the macroeconomic policy regime. The process was not triggered by the reforms; it was merely aided by them.

Fully understanding these processes would facilitate efforts in the policy arena. Entering into the design and implementation of policy actions without a clear analytical background of what has been happening all along -and blindly accepting the idea that markets function well and that opening up to external competition and privatizing and deregulating economic activities is 
enough to stimulate an optimal adjustment process- would probably not produce socially desirable results in terms of the structure and performance of the various manufacturing activities in the economy. A complex research agenda lies ahead, with many new questions. Some of these questions are explored later in this book.

Table III.7 ARGENTINA: STRUCTURAL CHANGE, ENTRY AND EXIT OF FIRMS IN
THE IRON AND STEEL INDUSTRY, 1975-1992

\begin{tabular}{|c|c|c|c|c|c|}
\hline & 1975 & 1980 & 1985 & 1990 & 1992 \\
\hline \multirow[t]{6}{*}{ Integrated } & Altos Hornos & Altos Hornos & Altos Hornos & Altos Hornos & Altos Hornos \\
\hline & Zapla & Zapla & Zapla & Zapla & Zapla \\
\hline & & Somisa ${ }^{a}$ & Somisa ${ }^{a}$ & Somisa ${ }^{a}$ & Aceros \\
\hline & & Acindar & Acindar & Acindar & Paraná \\
\hline & & Siderca & Siderca & Siderca & Acindar \\
\hline & & & & & Siderca \\
\hline Total integrated & 1 & 4 & 4 & 4 & 4 \\
\hline \multirow[t]{12}{*}{ Semi-integrated } & Aceros & Aceros & Aceros & Aceros & Aceros \\
\hline & Bragado & Bragado & Bragado & Bragado & Bragado \\
\hline & Aceros & Gurmendi & Tamet & Tamet & \\
\hline & Ohler & La Cantábrica & & & \\
\hline & Acindar ${ }^{b}$ & Santa Rosa & & & \\
\hline & Cura Brothers & Tamet & & & \\
\hline & Gurmendi & & & & \\
\hline & La Cantábrica & & & & \\
\hline & Mairimi\&Sinai & & & & \\
\hline & Santa Rosa & & & & \\
\hline & Siderca & & & & \\
\hline & Tamet & & & & \\
\hline Total semi-integrated & 10 & 5 & 2 & 2 & 1 \\
\hline Total mills & 47 & 38 & 36 & 33 & 21 \\
\hline Total industry & 59 & 47 & 42 & 39 & 26 \\
\hline
\end{tabular}

Source: Daniel Azpiazu and Eduardo Basualdo, "La internalización reconsiderada: el caso de Siderar", Buenos Aires, Facultad Latinoamericana de Ciencias Sociales (FLACSO), 1995 (unpublished).

a/ Sociedad Mixta Siderúgica Argentina.

$\mathrm{b} /$ Industria Argentina de Aceros. 
CHAPTER IV

TECHNOLOGICAL CHANGE AND LABOUR PRODUCTIVITY GROWTH IN NONMANUFACTURING SECTORS: TELECOMMUNICATIONS SERVICES AND MINING

Thus far the discussion has addressed whether the Latin American manufacturing sector managed to close the relative labour productivity gap with the international productivity frontier in the last three decades, in particular after the market-oriented structural reforms were introduced in the 1990s. This chapter shows that many of the processes that took place in the region's industrial sectors extend to non-manufacturing fields as well, including telecommunications and mining. The acceleration in the growth rate of labour productivity in the 1990s and the gradual closing of the relative labour productivity gap with the international technological frontier were, in fact, more system-wide phenomena affecting many other production activities beyond industry itself.

\section{A. The Telecommunications Sector}

The Latin American countries have followed markedly different strategies for restructuring and modernizing their telecommunications industries. Some countries -notably Argentina, Chile, Mexico, Peru and, more recently, Brazil-opted for the privatization of the sector, although they pursued very different ideas about its simultaneous deregulation and the enforcement of discipline through competition from new entrants. At one extreme, Chile decided very early in the restructuring process to deregulate 
the sector and to allow for stronger competition. At the other extreme, Argentina and Mexico similarly privatized the telecommunications industry, but they accepted a temporary monopoly which was to last around a decade. Costa Rica and Uruguay, in contrast, chose not to privatize telecommunications. They have sought to modernize the sector technologically while retaining State ownership of fixed telecommunications services and allowing for deregulation and greater competition in mobile telecommunications and high value-added services.

Both strategies have had positive consequences in terms of accelerating growth, upgrading the quality of service and stimulating the technological modernization of the telephone system. All of the countries reduced their labour productivity gap vis-à-vis the international productivity frontier, with regard to both quality and quantity. Despite such widespread advances, however, the countries that implemented privatization in combination with market deregulation performed significantly better from the perspective of consumer's welfare than did those that opted for privatization in a monopoly context.

\section{Alternative Strategies and Labour Productivity Growth in the Latin American Telecommunications Industry}

Figures IV.1 and IV.2 show that labour productivity in the telecommunications sector increased substantially in the 1990s. This was the case both for the region as a whole and for each of the individual countries under study.

Initial conditions varied substantially across countries when authorities in the region first began to discuss the privatization of telecommunications services. Some countries -Argentina, for example- were significantly more pressed for fiscal resources than others, such as Chile. The Argentine government was therefore less concerned about promoting microeconomic efficiency in the sector than about securing the cash flow from the transaction. The initial heterogeneity among the countries of the region generated a wide range of privatization conditions, regulatory frameworks and bargaining capabilities of local public officials vis-à-vis interested multinational firms. Given such diverse experiences, each national case merits separate examination, irrespective of the fact that all the countries underwent technological modernization, sectoral upgrading and convergence with world's standards. 
Figure IV.1

\section{LATIN AMERICA AND THE UNITED STATES: PRODUCTIVITY IN THE TELECOMMUNICATIONS SECTOR, 1986-1996 \\ (Number of lines in services per employee)}

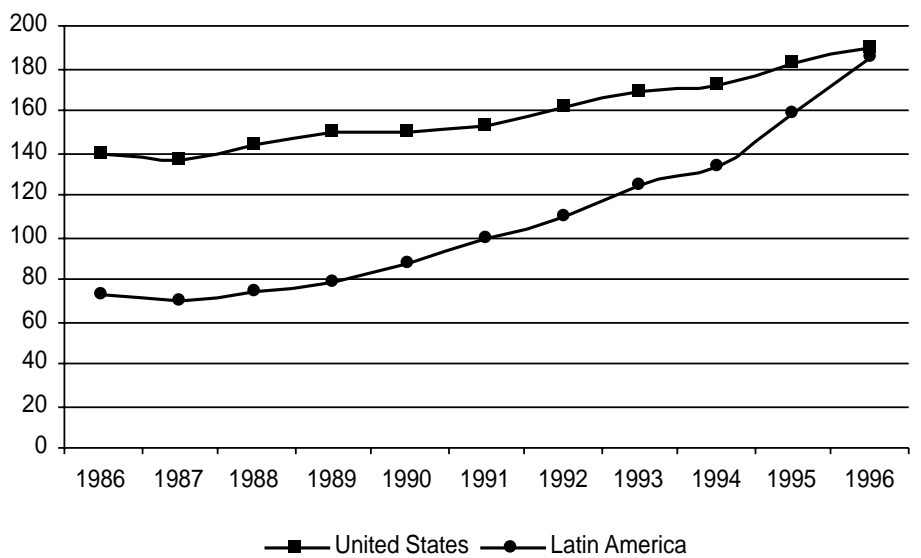

Source: Jorge Walter and Cecilia Senén González, La privatización de las telecomunicaciones en América Latina: empresas y sindicatos ante los desafios de la reestructuración, Buenos Aires, EUDEBA, 1998.

Figure IV.2

\section{ARGENTINA, BRAZIL, MEXICO AND URUGUAY: PRODUCTIVITY OF TELECOMMUNICATIONS, 1986-1996 (Number of lines in services per employee)}

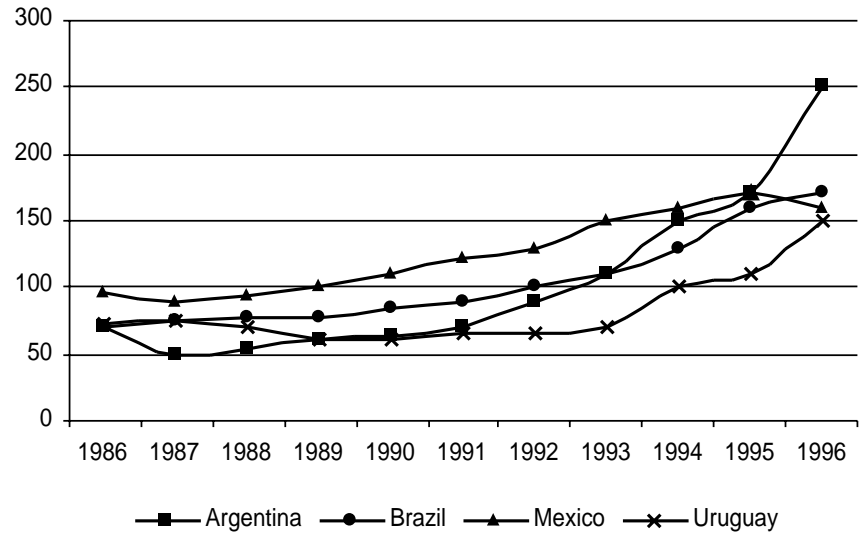

Source: Jorge Walter and Cecilia Senén González, La privatización de las telecomunicaciones en América Latina: empresas y sindicatos ante los desafíos de la reestructuración, Buenos Aires, EUDEBA, 1998. 


\section{The Initial Situation}

The performance of the telecommunications sector prior to the reforms was clearly disheartening (see table IV.1). Available literature on this topic offers several explanations for this poor performance. Some authors emphasize the bureaucratic-hierarchical governance model common in public enterprises. Public ownership is scarcely an organizational model inducing innovation and productivity growth. Public firms are described as having soft budget constraints and being governed by hierarchical and command relationships rather than by price signals, market rules and efficiency incentives. State firms are not subject to a conventional market discipline. Career advancement is dictated more by seniority than by performance. Dismissal is rare, and trade unions have a privileged position in the labour force. The hierarchicalbureaucratic model was quite prevalent among State firms in the region's telecommunications sector during the ISI period. Although these firms managed to grow and to earn a profit, they were neither innovative nor especially keen to increase productivity. They routinely planned the installation of new lines by means of public surveys, neglecting more sophisticated ways of projecting demand on the basis of consumer's purchasing power, the income elasticity of demand for telecommunications services and international comparisons. The outcome was that the number of lines grew at a ritualistic $3 \%$ to $4 \%$ per year, but dramatically long waiting lists accumulated for the installation of new lines as well as for the repair of the decaying physical infrastructure.

A second explanation of the prevailing inefficiency puts more weight on the deterioration of the operating conditions that these firms suffered in the 1980s as a result of the debt crisis. According to studies in Argentina and Chile (Moguillansky, 1999), firms entered a stage of dramatic financial disarray when governments attempted to use them as an instrument for macroeconomic stabilization during periods of high inflation. This explains why the privatization of the telecommunications industry received strong support from the population, as many people were frustrated by the low quality of service and the unresponsiveness of public firms to their needs. ${ }^{15}$

15. Walter and Senén González (1998, p.33) emphasize the stagnation that precedes privatization, an issue that is also addressed by Celani (1998, p.13). To explain the lack of reaction in Argentina to denationalization of the telecommunications industry, the ending of job guarantees and the division of the State company into two firms, Celani cites the "economic-financial disorder caused by the state of neglect of the lines, the exchanges and everything that had to do with business practice and investment." By contrast, in Mexico the transition from State ownership to free competition seems to have been relatively untraumatic (Walter and Senén González, 1998, p.43). 
Table IV. 1

\section{PERFORMANCE INDICATORS IN THE TELECOMMUNICATIONS SECTOR AT THE END OF THE 1980s}

\begin{tabular}{lcccccc}
\hline Performance indicator & Argentina & Chile & Brazil & Mexico & VenezUela & Standard \\
\hline Local calls completed (\%) & 49 & 97 & 39 & 92 & 49 & 96 \\
Long-distance calls & & & & & & \\
completed (\%) & 29 & 93 & n.a. & 90 & 31 & 89 \\
Lines out of service (\%) & 45 & 7 & 5 & 10 & n.a. & 3 \\
Repair time (days) & 14 & 3 & 2 & 4 & 4 & 2 \\
Installation time (days) & 600 & 10 & 300 & 100 & 180 & 4 \\
\hline
\end{tabular}

Source: A. Whilhelmus van der Krogt, "The Case of Telecom Services in Chile and Argentina", Ph.D. dissertation, Amsterdam University, 1996, p. 167.

Whether because they were highly bureaucratized firms to start with or because their performance deteriorated badly in the 1980s, the privatization of these firms brought about a major transformation of the structure and performance of the telecommunications industry within each country. The transfer of telecommunications firms to the private sector entailed significant changes in their modus operandi. The degree of vertical integration was reduced, and subcontracting was rapidly increased. Investment and technological strategies changed dramatically, as did firm ideology regarding labour relations, governmental relations and general public relations. It was nothing less than a quiet revolution, involving a shift from a hierarchical organizational model based on command to one founded on market rules and disciplines.

\section{The Institutional and Regulatory Framework}

Three main sets of factors seem to have influenced the way in which the privatization of the telecommunications sector was conducted in the region. The first concerns the nature of the regulatory framework and the requirements specified by the government for the tender. ${ }^{16}$ These legal instruments

16. On the Argentine case, see Celani (1998, p.15). The authorities' haste to make the transfer prompted some difficulties, such as the absence of a pre-sale regulatory body that could take part in the process from the outset. The National Telecommunications Commission was created after November 1990, and the privatization itself was overseen by other bodies that later played no role. 
established the minimum general conditions that winning firms were expected to meet. They also specified the minimum new investment and number of new telephone lines per year that the government expected out of the privatization process. Countries display enormous differences in the initial bargaining details that each specified for the privatization. In general, the newly arriving firms met their obligations, and the fixed telephone infrastructure expanded very rapidly, as did the rate of digitalization of the communication network.

Second, the internal culture and long-term strategy of the firm taking over the contract also played an important role in conditioning the outcome of the programme. Of particular importance in this regard was the firm's technological history, its participation in international alliances with other large telecommunications operators and its links with the international capital market. Many of the new operators entering the Latin American telecommunications sector were public firms in their respective countries, such as Telefónica (Spain), France Télécom, and Stet (now Telecom Italia). Some had a markedly engineering culture, whereas others were more customeroriented (Walter, 2000). ${ }^{17}$

Finally, the regulatory agency clearly influenced the evolution of the process. Some countries established the relevant regulatory agency before privatization, and the agency was thus able to play an active role in designing the regulatory framework for transferring the firm to private hands. Other countries set up the agency after the privatization had already taken place, when it was obviously much more difficult to change the rules without violating contracts, established property rights and credibility.

The complex interdependency between the regulatory framework, the investing firm's management culture and strategies and the activities of the regulatory agency significantly affected the sector's performance following privatization. In addition, the telecommunications industry gradually began to encounter increasing competitive pressure from mobile phones, cable television and, increasingly, the Internet. Incumbent operators were thus challenged to maintain their market position in the face of new technologies and new firms entering particular market niches.

Each of the actors participating in this market has undergone a process of adaptive learning. The institutional and regulatory environment slowly improved almost everywhere as competition became stronger. Local

17. In a recent study on Argentina's telephone privatization, Walter (2000, p.22) writes: “In particular, one company seems more geared to process changes (Telecom), while the other puts more emphasis in changing its image (Telefónica). The two strategies are reflected in different organizational structures (engineering leadership versus business leadership) and, of course, in investment policies (emphasis on the substitution of switching exchanges against emphasis on expanding the household network and replacing obsolete couplings in the household network)." 
institutions gradually assumed a growing role in the area of consumer protection, championing the right of marginal regions and consumers to be connected to the network. In light of such developments, it is fair to say that society as a whole benefited from privatization, as competition became more significant and the different actors gained experience with the new regime.

The privatization of the telecommunications sector in Latin America was thus marked by several common elements: (i) poor initial performance indicators; (ii) a weak regulatory environment (except in Chile and, more recently, Brazil, which capitalized on the experience and problems emerging from the earlier privatizations in Argentina and Mexico); (iii) varying degrees of fiscal urgency on the part of the privatizing government; and (iv) entry of new firms providing mobile telecommunications and value-added services, which challenged the market power of incumbent fixed telecommunications service providers. How did the structure and performance of the sector changed thereafter?

\section{New Investment and the Installation of Fixed Telephone Lines}

Because no single, universal story can adequately describe the regional experiences, a comparative examination of specific national cases is necessary to arrive at an understanding of the successes and failures of the privatization of telecommunications in the different countries. The process began in Chile in 1981, when the Corporación de Fomento de la Producción (CORFO) sold $80 \%$ of the stock of two regional service suppliers, the Compañía Nacional de Teléfonos and the Compañía de Teléfonos de Coyhaique, to VTR Telecommunications S.A. The 1982 General Telecommunications Law and its later modifications established the regulatory framework and the incentives regime under which the privatization of the Empresa Nacional de Telecomunicaciones (ENTEL) and the Compañía de Teléfonos de Chile (CTC) would occur a few years later. In 1986, 30\% of ENTEL was sold through the local stock exchange, and 1987 saw the start of the sale of CTC. The latter ended in 1988 with CTC's transfer to the Bond Corporation (an Australian firm) by means of public tender and the sale of shares. In the case of ENTEL, the transition phase lasted two more years, ending in 1990. That same year, the Bond Corporation sold its share in CTC to Telefónica of Spain, which had also acquired ENTEL stock in the stock exchange. ${ }^{18}$

18. The Chilean literature on these issues often represents the Bond Corporation as an opportunist firm that bid up the price of the company in a few years and then abandoned the business, leaving practically nothing behind in the local context. Interviews at different levels of CTC reveal that Bond's technological and organizational legacy was not so meagre, especially as regards the transition to cellular telephone service and the firm's opening to international capital markets. 
In Argentina, the first attempt to introduce private-sector participation in the telecommunications sector was made in 1987, during the presidency of Raúl Alfonsín. Telefónica again emerged as the international operator most interested in offering administrative management and technology to ENTEL, Argentina's State-owned fixed telephone company. For political reasons, ENTEL initially was to be restructured and upgraded, but not privatized. It was only in 1989, during the Menem administration, that ENTEL was slated for privatization. The basic telephone service was given to two operators, Telefónica de Argentina S.A. and Telecom de Argentina S.A. The former consisted of Spain's Telefónica (34\%), Citibank (20\%) and Techint, a private Italian-Argentine group (6\%). The latter comprised France Télécom (18\%), Italy's Stet (18\%), Morgan Bank (6\%) and Pérez Companc, a private Argentine group (18\%).

In Mexico, two large phone companies controlled the market before 1950, namely, Ericsson and a local firm that was later absorbed by the then-private Telmex. The State acquired a 51\% share of Telmex in 1972. Reprivatization of the firm began in 1990, when Telmex was sold to the Carso group and its partners, France Cables et Radio (an affiliate of France Télécom) and Southwestern Bell. This concession contemplated quality improvement commitments, a minimum $12 \%$ growth rate for the installation of new lines and respect for workers' rights to employment and collective bargaining. In 1995 the federal government passed the Federal Telecommunications Law. This law established the details of the regulatory framework that was to develop competition and give juridical security to investors, and it granted the winning company sole market presence until 1996.

As mentioned earlier, fixed telecommunications services were clearly poor in all of the countries in the region before privatization. Indeed, in the early 1980s the region had, on average, 7 lines per 100 inhabitants (with 12 in Argentina and 10 in Chile, Mexico and Costa Rica), against an average of almost 50 lines per 100 inhabitants in the developed countries. In the extreme case of Argentina, less than 50\% of telephone calls were properly completed, the waiting period for installing a line was estimated to be 5 years and the average repair time was 15 days.

The above does not mean, however, that the State firms did not grow and make money. Nor does it mean that they did not have significant in-house technological capabilities. Chile had 4 lines per 100 inhabitants in 1969 and almost 10 in 1988, when the Bond Corporation took charge of CTC. This implies a $4 \%$ annual growth rate, which can hardly be regarded as stagnation. Similarly, the number of lines per employee increased from 42 in 1969 to 66 when the firm was transferred to the Bond Corporation, and the firm invested about $\$ 370$ million (at 1996 prices) between 1969 and 1988, or about \$20 million a year.

The annual reports of CTC and ENTEL reveal that in the 1980s, gross fixed investment did not surpass $\$ 100$ million a year. In the period 1990-1994, 
this figure quadrupled to an annual average of about $\$ 400$ million. Investment growth was spectacular after 1996, surpassing $\$ 1$ billion a year. The telecommunications sector captured $5.5 \%$ of total annual gross investment in the period 1990-1997, which is more than double its share in the 1980s (Moguillansky, 1999). The dynamism of the sector is reflected in the fact that, in a rapidly growing economy, telecommunications grew faster than average. Such investment allowed an expansion from about 11 lines per 100 inhabitants in the 1980s to 25 lines today.

The Argentine case is similar. The sector was by no means stagnant under public ownership, but its growth rate was much lower than after privatization. Between 1991 and 1997, in contrast, the Argentine telecommunications sector shows investments of about $\$ 15$ billion, or some $\$ 850$ million annually. The sector was thus one of the most dynamic in the economy, capturing about $4 \%$ of total annual gross investment. Total telephone lines increased from $3,600,000$ lines, or about 12 per 100 inhabitants, before privatization to about 7,500,000, or about 24 lines per 100 inhabitants, in 1997.

\section{Other Indicators of Sectoral Improvement}

The discussion has thus far centred on conventional indicators of productivity (i.e., lines per worker) and sectoral performance (i.e., lines per 100 inhabitants). Both measures show that the privatized firms underwent clear improvements in the 1990s. Other indicators that support this conclusion include the following: (i) the system's degree of digitalization; (ii) the waiting period for receiving a new telephone line; (iii) available number of public telephones; and (iv) daily average pending repairs. All of these indicators demonstrate very significant improvements in the 1990s. Despite differences across countries, convergence with international standards is quite evident in each of the countries under examination (see, for example, figure IV.3).

Various other indicators of overall sectoral improvement can be found. Among them are the entry of new firms and human capital improvements. The industry's "fabric" became more dense and sophisticated. In the case of Argentina, for example, the entry of new equipment suppliers and subcontractors was quite considerable, as illustrated in table IV.2. Similar developments can be found in Chile. Both countries also exhibit a significant number of new software firms entering the market, first supplying services to the telecommunications industry and later expanding to other areas such as mining, air traffic control, military logistics, pension fund systems and health insurance. Firms like Sonda, North Supply and Rimpex exemplify such developments in Chile, where they contributed to building an increasingly sophisticated, complex information-technology culture in the 1990s. A similar phenomenon occurred in Brazil and Mexico. 
Figure IV.3

\section{LATIN AMERICA AND THE UNITED STATES: DEGREE OF DIGITALIZATION OF THE TELECOMMUNICATIONS SYSTEM, 1986-1996}

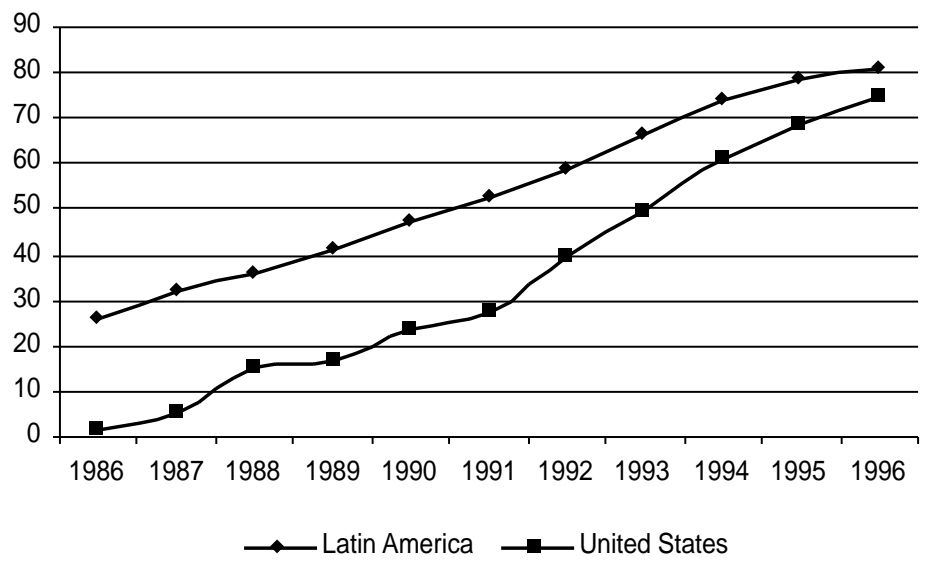

Source: Jorge Walter and Cecilia Senén González (eds.), La privatización de las telecomunicaciones en América Latina: empresas y sindicatos ante los desafíos de la reestructuración, Buenos Aires, EUDEBA, 1998.

Table IV.2

\section{ARGENTINA: GROWING COMPLEXITY OF THE ARGENTINE TELECOM PRODUCTION STRUCTURE AFTER PRIVATIZATION}

\begin{tabular}{|c|c|c|}
\hline Service & $\begin{array}{l}\text { PROVIDERS BEFORE } \\
\text { PRIVATIZATION }\end{array}$ & CURRENT PROVIDERS \\
\hline $\begin{array}{l}\text { Network of basic } \\
\text { telephone services }\end{array}$ & ENTEL & $\begin{array}{l}\text { Urban and intercity: } \\
\text { Telefónica } \\
\text { Telecom } \\
\text { International: } \\
\text { Telintar (Telefónica and Telecom) } \\
\text { Call Back (many United States companies) }\end{array}$ \\
\hline Alternative networks & ENTEL & $\begin{array}{l}\text { Mobile telephone service: } \\
\text { Miniphone (Telefónica and Telecom, for } \\
\text { the Federal Capital and } \\
\text { Greater Buenos Aires) } \\
\text { Unifón (Telefónica, southern region) } \\
\text { Personal (Telecom, northern region) } \\
\text { CTI North (except the Capital and Greater } \\
\text { Buenos Aires) }\end{array}$ \\
\hline
\end{tabular}


Table IV-2 continue

\begin{tabular}{|c|c|c|}
\hline Servilce & $\begin{array}{l}\text { PROVIDERS BEFORE } \\
\text { PRIVATIZATION }\end{array}$ & CURRENT PROVIDERS \\
\hline & & $\begin{array}{l}\text { CTI South (except the Capital and Greater } \\
\text { Buenos Aires) } \\
\text { Movicom (Federal Capital and Greater } \\
\text { Buenos Aires) } \\
\text { Cable (CATV): } \\
\text { Various modem cable suppliers }\end{array}$ \\
\hline New services & ENTEL & $\begin{array}{l}\text { Telefónica and Telecom only: } \\
\text { Information and repairs } \\
\text { Call waiting } \\
\text { Three-way conference } \\
\text { Call transfer } \\
\text { Answering machine } \\
\text { Alarm clock } \\
0600 \\
0800 \\
\text { Others }\end{array}$ \\
\hline $\begin{array}{l}\text { Supply of inputs } \\
\text { and equipment }\end{array}$ & $\begin{array}{l}\text { Siemens } \\
\text { Precom-NEC }\end{array}$ & $\begin{array}{l}\text { Siemens } \\
\text { Precom-NEC } \\
\text { Alcatel-Business } \\
\text { Ericsson } \\
\text { Motorola } \\
\text { Hewlett Packard } \\
\text { Others }\end{array}$ \\
\hline Subcontracting services & Techint & $\begin{array}{l}\text { Techint } \\
\text { Telsis } \\
\text { Teyma } \\
\text { Sintelar } \\
\text { Others }\end{array}$ \\
\hline
\end{tabular}

Source: Jorge Walter and Cecilia Senén González (eds.), La privatización de las telecomunicaciones en América Latina: empresas y sindicatos ante los desafíos de la reestructuración, Buenos Aires, EUDEBA, 1998.

Advances in the sector's structure and performance were accompanied by the rejuvenation and professionalization of its human capital, which has been recycled and upgraded through the incorporation of a younger, better trained crop of workers, engineers and technicians. For Argentina, figures IV.4 and IV.5 show that by the early 1990s, the upgrading of human capital had become an important part of the human resource management programmes of the new telecommunications companies. 
Figure IV.4

\section{TELEFÓNICA DE ARGENTINA: AVERAGE AGE AND TENURE OF PERSONNEL, 1990-1993}

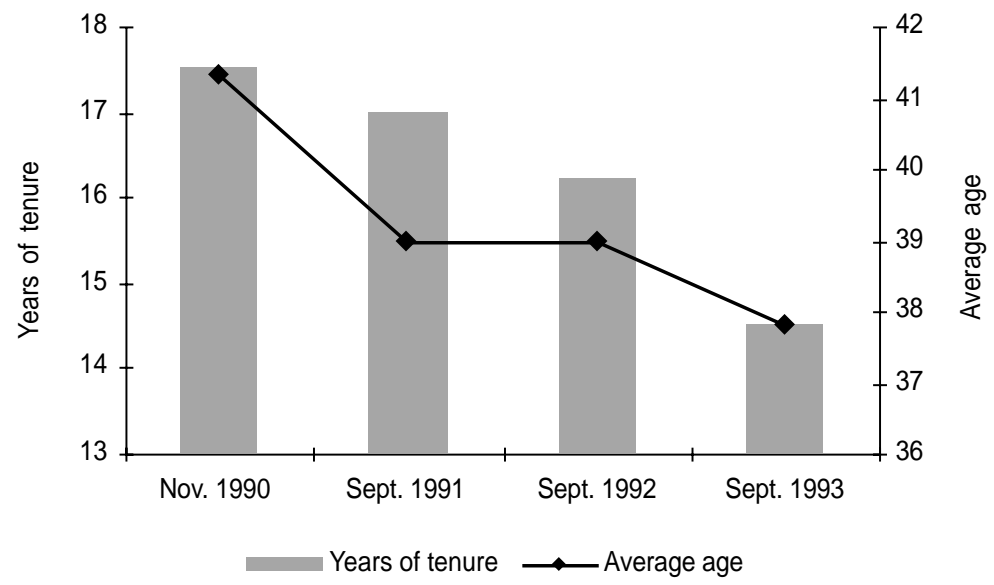

Source: Jorge Walter and Cecilia Senén González, La privatización de las telecomunicaciones en América Latina: empresas y sindicatos ante los desafios de la reestructuración, Buenos Aires, EUDEBA, 1998.

Figure IV.5

TELEFONICA DE ARGENTINA: PROPORTION OF PROFESSIONALS IN THE WORKFORCE

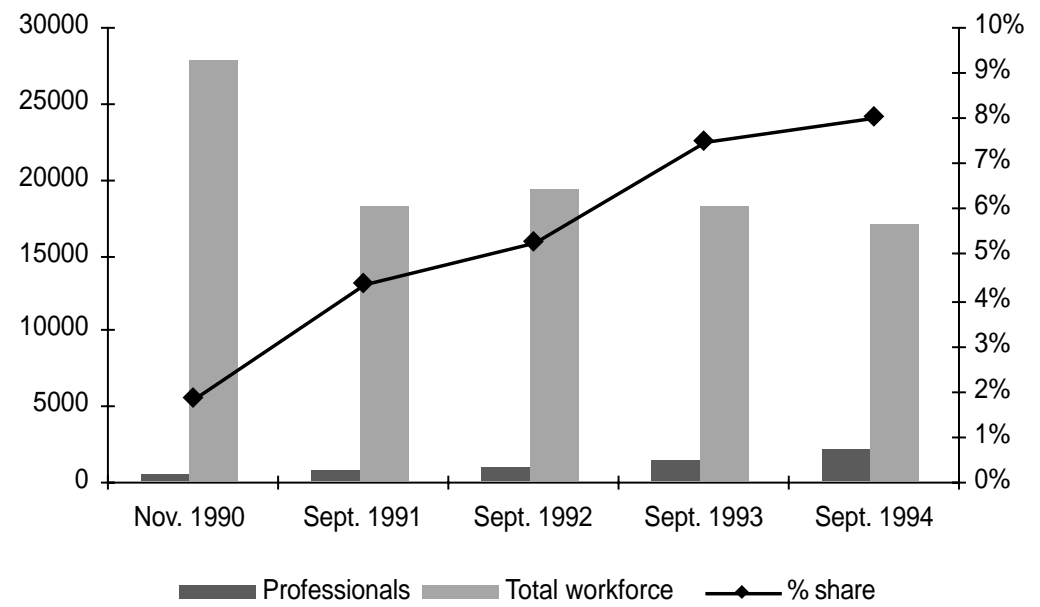

Source: Jorge Walter and Cecilia Senén González, La privatización de las telecomunicaciones en América Latina: empresas y sindicatos ante los desafios de la reestructuración, Buenos Aires, EUDEBA, 1998. 
Walter and Gore (1996) describe the situation in Argentina as follows: "Telefónica recently opened its training centres in a 25,000 square meter building to train operational, technical and executive staff. In 1993, Telecom invested $\$ 4.5$ million in remodelling an old ENTEL building into a training centre. This covers 6,600 square meters, with a capacity of 800 students per day, and includes 10 multimedia classrooms, 12 laboratories, and a documentation centre connected to databases from all over the world.... Training is provided by technicians from the equipment and technology suppliers, particularly in relation to digital technology and fibre optics. The courses are open to other companies linked to Telecom, such as Startel, Movistar and Telintar." The authors estimate that Telecom devotes some 52 hours per employee per year to training, which is equivalent to about $3 \%$ of total hours worked. This approaches the standards of France Télécom. ${ }^{19}$ These findings suggest that the upgrading of human capital parallels the modernization of the firm's hardware, and that embodied and disembodied technological change are closely complementary and inseparable.

\section{Privatization versus Modernization of State-Owned Telecommunications Firms}

Costa Rica and Uruguay chose to follow a different route from that pursued in Chile, Argentina and Mexico. They retained State ownership over basic telecommunications services but introduced stronger competitive pressure by deregulating mobile telecommunications and high value-added services. Both countries have had considerable success in their attempts to modernize State-owned fixed telephone companies.

A recent study of the Uruguayan case describes the transformation as follows: "The number of telephone lines in use currently surpasses the figure considered acceptable for a country with a per capita GDP like Uruguay's. This is estimated at about 23 telephones per 100 inhabitants by the International Telecommunication Union. The whole network was digitalized by July 1997, and practically no demands for new lines go unmet. In other words, Uruguay has performed extremely well in the Latin American context without

19. By way of example, the authors examine a training programme to familiarize workers with the use of digital measuring instruments. External instructors are included on the teams in each operational unit. The authors estimate that some 3,200 people received training in this programme, with each course lasting 360 hours per team. With regard to the impact of training on the productivity of the firm, the authors cite a worker who claimed that before training each team fixed three to four faults a day, whereas now they fix six to seven. After comparing performance per team before and after the training, the authors estimate performance improvements of about $60 \%$. See Walter and Gore (1996). 
privatizing the sector as did other countries of the region.... According to surveys carried out in 1988, 26\% of the population said that ANTEL worked well or very well. The percentage had climbed to $80 \%$ by 1994 , when ANTEL broke Movicom's monopoly in mobile telecommunications services, created its own company and began to compete in the market" (de Wolf, 1998, p. 246).

Costa Rica offers another example of successful performance without privatization. A recent study by Barbosa (1999) reveals that the number of telephones per 100 inhabitants increased from just 10 in 1987 to 20 in 1997. Such coverage is comparable to that of Chile, Argentina and Uruguay, which are the most advanced cases in the region.

The acceleration of technological upgrading in Costa Rica's telecommunications sector took place in the 1990s and is thus very recent (see table IV.3). Even so, the number of employees at the Instituto Costarricense de Electricidad (ICE) per 1,000 telephone lines fell from 10 to 6 in the decade. In the late 1990s, the United States firm Millicon was eliminated from the mobile telephone business and absorbed by ICE, following a lawsuit arguing that the concession of the service to Millicon was unconstitutional. As in Uruguay, the State company has taken charge of accelerating the local diffusion of mobile telecommunications technology.

The final message of the experiences in Costa Rica and Uruguay is that the privatization of public telephone companies was not the only way of inducing their technological modernization. It is the discipline of markets, the so-called invisible hand of competition, and not necessarily who owns the company, that induces technological change, innovation and, consequently, lower costs and prices. When privatization and market deregulation were implemented simultaneously (as in Chile), the technological modernization of the sector brought about significant welfare gains to local consumers. On the other hand, when the privatization of public firms occurred under monopoly conditions (as in Argentina or Mexico) prices did not fall significantly, until after the industry began to feel the challenge of mobile telecommunications services in the 1990s. The deregulation of the sector and the entry of new suppliers of mobile and high value-added services -including Internet- is what forced the incumbent fixed telecommunications firms in Argentina and Mexico to reduce telephone charges and lower their profits.

\section{The Development of Regulated Competition in the Telecommunications Sector}

Laffont and Tirole (1998) present a pioneering exploration of the development of regulated competition in network industries such as telecommunications, electricity and gas. These sectors operate through the interconnection of nodes, which move from generating centres, through 
Table IV.3

\section{COSTA RICA: INDICATORS OF PRODUCTIVITY AND COMPETITIVENESS IN THE TELECOMMUNICATIONS SECTOR,} 1987-1997

\begin{tabular}{|c|c|c|c|c|c|c|c|c|c|c|c|}
\hline INDICATOR & 1987 & 1988 & 1989 & 1990 & 1991 & 1992 & 1993 & 1994 & 1995 & 1996 & 1997 \\
\hline Number of workers & 3,170 & 3,174 & 3,262 & 3,267 & 3,245 & 4,269 & 4,907 & 5,410 & 5,307 & 4,434 & 4,547 \\
\hline Workers per 1,000 lines & n.a. & 10.9 & 10.8 & 10.6 & 9.9 & 9.8 & 9.5 & 8.8 & 8.4 & 7.3 & 6.3 \\
\hline \multicolumn{12}{|l|}{ Lines } \\
\hline Installed (thousands) & 283 & 287 & 302 & 308 & 324 & 338 & 408 & 500 & 543 & 628 & 694 \\
\hline \multicolumn{12}{|l|}{ Use of installed } \\
\hline capacity (\%) & 0.84 & 0.89 & 0.90 & 0.90 & 0.90 & 0.95 & 0.89 & 0.86 & 0.88 & 0.83 & 0.85 \\
\hline \multicolumn{12}{|l|}{ Pending demand } \\
\hline (thousands) & n.a. & 13.9 & 29.1 & 45.3 & 63.8 & 71.7 & 84.0 & 61.0 & 66.1 & 78.4 & 49.4 \\
\hline \multicolumn{12}{|l|}{ Density per 100} \\
\hline inhabitants & 10.1 & 10.2 & 10.3 & 10.4 & 10.6 & 10.7 & 13.2 & 14.5 & 16.2 & 17.89 & 19.5 \\
\hline \multicolumn{12}{|l|}{ Calls completed (\%) } \\
\hline National & n.a. & 54 & 50.8 & 49.6 & 50.1 & 49.9 & 47.0 & 46.3 & 48.8 & 50.3 & 52.0 \\
\hline International & n.a. & 58 & 56.1 & 67.3 & 57.2 & 58.2 & 55.8 & 55.8 & 68.5 & 59.3 & 60.0 \\
\hline \multicolumn{12}{|l|}{ Response to breakdowns } \\
\hline in $24 \mathrm{hrs}$ or less & n.a. & 76.8 & 73.8 & 58.2 & 58.3 & 44.8 & 35.0 & 36.1 & 68.4 & 75.8 & n.a. \\
\hline
\end{tabular}

Source: Gustavo Barbosa, “Crecimiento, empleo y equidad en América Latina: cambio tecnológico en el sector de energía y telecomunicaciones en Costa Rica", Economic Science Research Institute (IICE), San José, Costa Rica, University of Costa Rica, unpublished, 1999.

switching, to the user's home. Such activities have high fixed costs and large economies of scale, and they have long been considered the typical case for public monopolies. The monopoly situation fosters significant inefficiencies, however. "At least two large sets of factors have encouraged the movement in favour of institutional reform in industries of this sort. On the one hand, the monopolist has few incentives to reduce costs. If resources are squandered, prices are adjusted such that the monopolist recovers his 'desired' rate of return. No great understanding of incentives theory is necessary to see that the 'costplus' nature of industries with a regulated rate of return do not exactly tend to perform brilliantly as regards costs and prices" (Laffont and Tirole, 1998, p. 4).

According to Laffont and Tirole, the deregulation and privatization of industries of this sort stems from the perception that they do not promote innovation or the maximization of consumer welfare. Technological change would offer potential new entrants greater capacity to respond to consumer demand, but their entry tends to be blocked by discriminatory pricing on the part of incumbent firms. 
In the 1980s, several English-speaking countries tried to set price caps in the telecommunications sector. They fixed a ceiling on the average service price that the incumbent firm could charge, but let the company apply price discrimination in response to demand elasticities and competitive pressure in particular market segments. The assumption was that the use of maximum prices would produce incentives for the incumbent to invest in expanding and adequately maintaining the industry's infrastructure. This model was not successful, however. First, the regulator had incomplete information about the producer's costs; this hampered the fixing of precise maximum prices and prompted unwanted fluctuations in the incumbent's rate of return. Second, the setting of price caps induced firms to "capture" the regulatory agency. Third, it aroused legitimate concerns that the incumbent firm could reduce maintenance expenditure beyond reasonable limits with the purpose of lowering production costs.

In light of such difficulties, the deregulation and liberalization of the industry appeared to constitute another possible alternative, since an impersonal market mechanism would regulate prices and service quality. Unfortunately, things are not that simple. Given the high capital costs incurred by the incumbent firm, barriers to entry are extremely high, which hinders the creation of a truly competitive market. New entrants must use the physical infrastructure owned by the dominant firm, and the associated access tariff is hard to estimate a priori. This entry cost normally constitutes a significant fraction of the production costs of new entrants (Laffont and Tirole estimate it at up to $50 \%$ ). It is also a significant source of income for the incumbent, and a key determinant of its rate of return on investment. It thus has a substantial impact on the company's propensity to invest, thereby affecting the growth rate of the network and its maintenance. This is the source of a key regulatory dilemma: a very high access fee prevents entry and negatively affects consumer welfare; a very low access fee negatively affects the incumbent firm's rate of return and its propensity to invest.

The foregoing analysis highlights the complexity of the regulatory problem and the difficulty of balancing the two sides of the dilemma. ${ }^{20} \mathrm{In}$ Latin America, this is currently the crux of the matter in the telecommunications

20. In a recent newspaper article, the general director of Chile's CTC wrote: "The experience of the last five years indicates that fixing interconnection tariffs is the cornerstone of competition in telecommunications. Without fairly priced interconnections, there can be no competition. If local firms are not adequately compensated, there will be little incentive to invest in local telephone service. At the same time, if interconnected competitors are charged more than a fair price for the use of the infrastructure, they will have no incentive to enter the market. If they are charged less than fairly, many operators will enter the market, but this will not foster investment in infrastructure.... Thanks to the introduction of competition, and as the result of the decline in access charges, long-distance national calls increased by a factor of 2.2, and prices fell by 28\%" (El Mercurio, Monday, 10 May 1999; author's translation). These remarks show the importance of this issue for the growth rate of the network and consumer welfare. 
field. The key question seems to be how to develop new forms of regulated competition in each country given the prevailing technological and competitive regime. The pace at which the telecommunications sector is to grow in the future and the extent to which it will pass on the benefits of technological modernization to consumers will be closely related to the way in which institutions mature and develop on this front.

\section{B. The Mining Sector}

Many of the issues examined above in relation to the recent transformation of the Latin American telecommunications sector carry over to the mining sector. Here, too, the relative productivity gap with industrialized countries narrowed significantly in the 1990s, as a result of both the arrival of foreign firms that introduced new production and organizational technologies and the technological upgrading of local companies. This process involved the coevolution of economic, technological and institutional forces. In the 1980s and 1990s, many Latin American countries introduced fundamental changes in the property rights regime governing the mining sector. This institutional reform caused a massive inflow of foreign private investment into the Chilean, Argentine and Peruvian mining sectors, triggering a major transformation of the industry's technological and organizational regime. Particularly in the case of Chile, local engineering firms, domestic suppliers of simple capital goods and intermediate inputs (such as pumps, motors, mechanic belts and explosives), public and private institutions involved in the training of human resources, research and development laboratories in universities and technical schools and various other actors in the mining sector all experienced a gradual process of learning and upgrading over the course of the 1990s. As in the case of telecommunications, this process was essentially a system-wide evolutionary event involving the gradual development of a new mining culture within the local society.

\section{Institutions, Property Rights and Investment in the Latin American Mining Sector in the $1990 s^{21}$}

Latin American countries have recently shifted from a paradigm of national sovereignty, under which mines, oil fields, waterways and forests were defined as public property, to one of private property, under which the private ownership of these resources is granted as a constitutional right to both national and foreign firms.

21. This section draws on Moguillansky (1999), who analyses the impact of structural reform on mining investment in Latin America. 
Chile was the first to move in this direction with the modification of its investment law in 1974 (Decree Law 600), right after Gen. Pinochet came to power. This aggressive strategy would later be followed by Argentina, Brazil and Peru. The change in the property rights regime was part of a more general market-oriented renovation of the overall policy regime, whose main purpose was to attract large multinational investors to the country. In a complementary move specifically aimed at the mining sector, the Government granted special tax concessions to foreign mining firms investing in new mines.

Chile's new constitution of 1980, Peru's Decree 708 of the early 1990s and Argentina's amendments to the mining legislation of 1993-1995 significantly altered the institutional and fiscal landscape surrounding the mining sector. These changes, together with the high quality of the available natural resources, led to a sharp increase in investment from both foreign firms and large domestic conglomerates. The opening of new mines in recent years, in turn, significantly altered sectoral performance and market structure.

\section{Changes in Industrial Organization in the Mining Sector}

Further understanding of the systemic nature of the sectoral process of technological upgrading experienced in the region in the 1990s must take into account the multiplicity of firms and institutions that make up a country's mining industry at any given point in time. These include the mining companies directly involved in the extraction and refining of different metallic and non-metallic minerals, equipment and intermediate-input suppliers, engineering firms, public R\&D institutes in universities and technical schools. To varying degrees, all of these actors take part in the system-wide transformation induced by the rapid expansion of the industry, through the development of downstream effects, externalities (positive and negative) and synergies.

As far as mining itself is concerned, four different types of firms can be identified: public mining companies, locally owned mining conglomerates, subsidiaries of large transnational corporations and small and medium-sized firms. The different downstream impacts of these four types of firms emerge quite clearly in an analysis of the structure and performance of each (Cáceres, Cárdenas and Katz, 2000).

The Chilean case is a good example of the differences in organization and behaviour that are commonly found among the different types of mining companies. The State firm Codelco (Corporación Nacional del Cobre) in many ways confirms the conventional stereotype of a slow, bureaucratic firm, burdened with ritualistic practices and routines. Codelco staged a dramatic process of transformation and modernization in the 1990s, however, and is now in the transition towards becoming a globalized, transnational enterprise, 
breaking with the stereotype of the past. Codelco is the world's largest copper producer $(1,300,000$ tons of fine copper per year). It employs close to 18,000 people. Four of the five mines that it exploits are old, which is why its average productivity is lower than that of firms that exploit new, high-grade deposits. In 1994, Codelco began an extensive programme of new investments involving a drastic process of organizational and technological modernization. Many of the engineering services demanded for such programme were contracted locally. Transport, equipment maintenance and other production services were subcontracted to small engineering firms operating within the mines themselves. Codelco created its own research and development centre in the mid-1990s, and took active steps in the direction of establishing strategic alliances with global players in the international mining industry. Two aspects of Codelco's long-term market behaviour reflect the fact that it is a public firm: first, investment in new production facilities is strongly dependent on the availability of fiscal resources, which introduces an element of vulnerability in its long-term performance; and second, the firm makes strong efforts to develop downstream technological capabilities among local engineering firms as well as among suppliers of different types of machinery and intermediate inputs. It regards such efforts as socially profitable, even if they might not be so from the point of view of profit maximization as typically pursued by the private sector.

Private, locally owned mining conglomerates face a different set of restrictions and opportunities than do public firms such as Codelco. The Sociedad Química y Minera de Chile S.A. (Soquimich) is a good example of this second type of mining company. Soquimich is a mining conglomerate that produces iodine, nitrates and other non-ferrous items for the world market; it employs close to 3,500 people. In 1988 the firm embarked on a largescale investment programme aimed at modernizing production facilities and equipment and expanding its product mix. This strategy required the firm to undertake a large number of new projects involving $R \& D$, basic engineering and project design efforts, for which it created its own research department. The firm acquired mining rights for new investment projects both in Chile and abroad; it started major exploration programmes, established strategic alliances with international firms and secured financing by issuing American Depository Receipts (ADR). All available evidence indicates that Soquimich is currently running an ambitious programme aimed at establishing itself as a global player in the world's mining sector.

A third important group in the mining industry comprises large transnational corporations with central headquarters and R\&D facilities in mining countries such as Canada, the United States or Finland, but which exploit mines worldwide. These firms generally operate in developing countries by means of local subsidiaries that carry out the actual mining activities with little involvement in domestic R\&D or engineering efforts, aside 
from what is strictly necessary for an efficient operation. The geographical advantages arising from the high quality of the existing resources in a given country, together with the local institutional and legal environment, are crucial factors in the investment choices made by firms of this sort. They do not come to a country with the purpose of developing local technological capabilities or a domestic R\&D infrastructure. They normally use international sources for equipment and machinery, as well as for engineering services. Their organizational and technological behaviour thus differs from that of the two previously examined cases, coming closer to the enclave prototype whose central feature is that of having low value added at the local level.

Minera Escondida Ltda. is a good example of this situation in the Chilean case, although the firm has a significant downstream impact related to environmental protection, urban development, shipping infrastructure and so forth. Escondida is Chile's second main copper producer (about 1,000,000 tons of fine copper a year), and it employs about 2,000 people. The firm belongs to a consortium of multinational companies. The copper mine it owns has been under exploitation since 1990; not only is it rich in copper, but it also contains large reserves of gold. The firm's production process was developed entirely outside the country, and practically all the engineering services required for start-up were provided by international engineering subcontractors. Escondida makes few efforts in exploration for new local deposits. Generally speaking, the firm acts conservatively, since it exploits a new, high-grade, deposit and does not need to involve itself in major local engineering efforts. The quality of the deposits guarantee high profits even with low downstream efforts to create domestic technological capabilities.

Finally, the fourth type of mining company is the small or medium-sized firm that exploits marginal deposits using labour-intensive technologies. These firms generally lag far behind international production organization and productivity standards, and because their operations are not environmentally sustainable, they often present difficulties for public policy in the mining field. The number of mining companies of this sort fell sharply in Chile in the 1990s, from 120 to about 12, while their labour force declined from 4,500 employees to less than 1,000 . Small entrepreneurs are generally leaseholders, rather than owners, of mines whose exploitation is very costly and of very low yield (Cáceres et al, 2000).

In sum, the Chilean mining industry exemplifies the major differences in structure and performance that normally prevail among public mining firms, domestically owned conglomerates, subsidiaries of transnational corporations and SMEs. These firms face different opportunities and constraints, such that they can be expected to have a different downstream impact on the development of domestic technological capabilities, including the development of local engineering firms, support for domestic suppliers of intermediate inputs and machinery and the creation of human capital in universities and technical schools. 
Only a small number of Latin American engineering firms have the capacity to manage large investment projects in mining. Basic processengineering know-how is normally supplied by international subcontracting companies such as Fluor Daniel and Bechtel. With regard to detail engineering and construction services, Chile exhibits a fairly strong domestic base of national engineering firms which, in partnership with the above-mentioned international firms, are able to take an active role in setting up mining operations and erecting and maintaining refineries. In 1996, the three main international engineering firms based in Chile employed 7,300 people, while a dozen Chilean firms, which are smaller and less technologically advanced, employed just over 2,000 professionals. These companies are mostly engaged in the design and implementation of minor technological improvements in established production facilities, although to a lesser degree they also participate in the erection of new production sites. Such domestic capacity is less common in Argentina and Peru.

Large international suppliers of mining equipment also play an important role in this industry. In recent years, equipment suppliers have demonstrated an increasing tendency to set up operations locally and to be physically present in the mines, replacing the conventional "arm's length" sales of machinery and equipment with a complete package of collateral engineering services related to their installation, followed by post-sales servicing. Capital goods suppliers have thus moved into the creation of on-site technical departments that provide real-time technical assistance at the mine or refinery. The growing importance of the region's mining industry has led to a reduction in delivery times and in the time lag between the first international use of a new type of capital equipment and its use in the region. In this respect, the gap with international technological standards has clearly been falling .

\section{Technological Changes in the Mining Sector}

Technological progress in the mining industry comes in the form of either large changes in process technology, which are usually associated with major changes in machinery and equipment, or minor technical changes, which encompass incremental changes in both organizational and process technologies. They each play an important role in explaining the industry's long-term global performance, and they contribute to the forces that condition the performance of individual firms.

Consider the following newspaper quotation: "Chuquicamata will continue to produce for at least another 25 years (it opened up in 1915), by which time the mine will be more than a kilometre deep. For more than 80 years, Chuquicamata has provided the country with more than 10 million tons of copper. Although it is likely to continue to produce, it has undeniably 
aged.... Production is now centred in low-return zones; the mineral grade has fallen to below $1 \%$ as a result of the exhaustion of the best areas" ( $E l$ Mercurio, 26 August 1998; author's translation). This is reflected in figure IV.6, which shows that there is a negative correlation between the age of a copper mine and output. The grade of the extracted mineral declines as the mineralogical complexity of the deposits increases through time.

The need to counteract this negative structural feature induces mining firms to engage in the production of incremental units of technical knowledge, as they search for process improvements that would allow them to cut costs and sustain output simultaneously. These incremental units of technical knowledge are called minor technical changes. In the mining sector, however, the accumulated impact of so-called minor technological changes has a significant aggregate impact on the general performance of the firm.

Technological change that is embodied in new machinery and transport equipment is paramount for a firm's performance. In the mining sector, embodied technological change is concentrated in three main areas: (i) the mine; (ii) the refining process; and (iii) environmental protection.

Figure IV.6

\section{CHILE: COPPER GRADE OF THE CHUQUICAMATA MINE, 1976-2000}

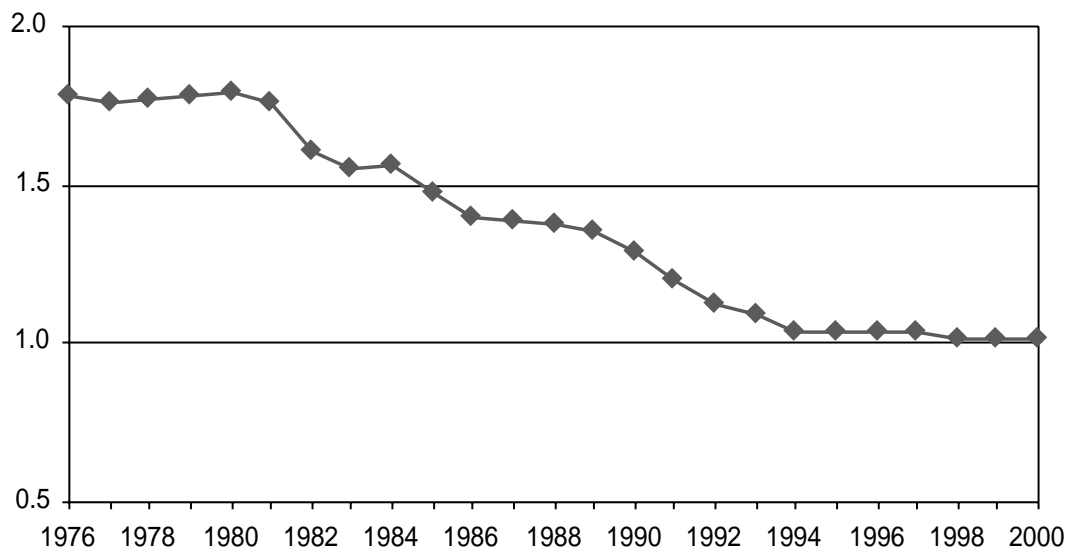

Source: Author's calculation, on the basis of the annual reports of the Corporación Nacional del Cobre de Chile (Codelco-Chile). 
With regard to the mine, firms generally act as passive recipients of major technological changes embodied in new pieces of capital equipment designed by equipment suppliers. Trucks and other pieces of transport equipment are a good example in this respect. The increasing complexity of transport equipment generated a trend towards subcontracting the necessary transport services at the mine, leaving responsibility for truck dispatch and maintenance with the supplier. What the firm actually acquires are effective hours of transport services delivered at the mine.

Similarly, the region is not especially active in terms of $R \& D$ and engineering efforts aimed at the design and construction of new production processes. Most firms subcontract their basic engineering technology under turnkey conditions with major international contractors like Fluor Daniel or Bechtel. One of the few exceptions in this respect is the leaching technology developed recently by Codelco; the firm has even had a degree of success selling the leaching technology internationally.

Finally, technological efforts related to environmental protection are also important in this sector. Investment is substantial, particularly in waste management and control and in technology to reduce smelter pollution. Codelco, for example, spent more that $\$ 700$ million on environmental protection between 1994 and 1999 (see table IV.4).

Table IV.4

CHILE: CODELCO INVESTMENT IN ENVIRONMENTAL PROTECTION, 1994-1999

(Millions of dollars)

\begin{tabular}{llrc}
\hline PROJECT & \multicolumn{1}{c}{ Division } & 1997 & $1994-1999$ \\
\hline Capture and treatment of gases & Chuquicamata & 6.1 & 64.3 \\
Arsenic suppression plan & Chuquicamata & $\ldots$ & 40.0 \\
Management and cleaning gases & & & \\
at Potrerillos smelter & El Salvador & 16.6 & 47.9 \\
Potrerillos acid plant & El Salvador & 4.7 & 98.0 \\
Los Leones tailings deposit & Andina & 6.8 & 56.8 \\
Ovejería dam deposit & Andina & 64.3 & 243.9 \\
El Teniente acid plant & El Teniente & 26.5 & 73.0 \\
Third-stage of Carén dam & El Teniente & 3.0 & 35.8 \\
Other smaller projects & & 4.1 & 79.1 \\
Total & & 132.1 & 738.8 \\
\hline
\end{tabular}

Source: Jaime Cáceres, Kattia Cárdenas and Jorge Katz, “Instituciones y tecnología en el desarrollo evolutivo de la industria minera chilena", Reformas Económicas series, No. 53 (LC/L.1349), Santiago, Chile, Economic Commission for Latin America and the Caribbean (ECLAC), 2000. 


\section{Prospects}

The Latin American mining industry is undergoing a process of rapid structural transformation. This process involves economic, institutional and technological factors that evolve together, reinforcing the industry's convergence with international best practices. Changes in property rights and in the fiscal treatment granted to international mining firms in the region, as well as the availability of high-quality mineral deposits, caused a massive inflow of foreign direct investment in the mining sector in the 1990s. This strongly affected the structure and performance of the sector in countries such as Argentina, Chile, Brazil, Mexico and Peru. Chile and Brazil developed relatively strong downstream effects involving domestic engineering firms as well as local suppliers of intermediate inputs and capital equipment. In contrast, the mining sector in Argentina, Peru and Mexico more closely resemble an enclave industry.

In the case of Chile, State-owned Codelco was instrumental in fostering such strong downstream effects. Domestic technological capabilities diffused among local engineering firms, suppliers of capital goods and intermediate inputs, public R\&D institutes and engineering departments at universities and technical schools are therefore stronger in Chile than in other countries in the region. Foreign firms that have recently entered the region's mining sector show little interest in engaging in the development of a strong local technological infrastructure. These firms operate mostly on the basis of foreign know-how and equipment, and given that they normally exploit new, highgrade mines, they do not need to undertake in-house technological efforts.

Thus, the future long-term enhancement of domestic technological capabilities is not particularly promising, aside from the developments in Chile and Brazil. Enclave economies are often criticized for their low domestic value added and their scarce impact on the development of technological capabilities in the recipient environment. The current expansion of the mining sector in Latin America does not seem to be much different in this respect. Mining cycles are closely linked to the quality of available resources and to international prices. The current growth in mining investment could eventually decline, prompting a downward cycle similar to those already experienced by the mining industry in earlier periods. Under such circumstances, it is crucial for Latin American countries to seek to maximize the systemic effects of the sector's current rapid expansion. This requires governments to take a proactive policy stance, an issue that is addressed in the final chapter of this book. 


\section{Chapter V}

\section{THE IMPACT OF STRUCTURAL REFORMS ON EMPLOYMENT, THE TRADE BALANCE IN MANUFACTURING AND THE RELATIVE PRODUCTIVITY GAP BETWEEN SMALL AND LARGE FIRMS}

The two previous chapters examined how labour productivity growth and the labour productivity gap with the international frontier evolved over the last two decades in several countries of the region, both in manufacturing and in non-manufacturing sectors such as telecommunications and mining. The available empirical evidence shows that some countries (and industries) managed to partially close the gap with the international frontier-represented by United States manufacturing productivity- while others did not. The evidence also suggests that new problems have emerged as a result of market failures, information asymmetries, monopolistic practices and so forth.

This chapter investigates three specific topics: employment generation and destruction associated with recent structural reforms; the evolution of the relative productivity gap between SMEs and large firms; and the impact of recent changes in production specialization on the region's external balance of trade. All three areas raise new questions and challenges that will have to receive specific attention in the regional policy agenda for the future.

\section{A. Employment}

Chapter III showed that labour productivity growth in the 1990s was less the result of a rapid expansion of output than of a strong expulsion of labour 
in the more successful areas of manufacturing production. This was especially true in Argentina, Brazil and Uruguay. In contrast, Chile enjoyed considerable job creation in the 1990s, after having had open unemployment rates of over $20 \%$ in the 1970 s. $^{22}$

Tables V.1, V.2 and V.3 examine the inter-industry relation between closing the relative labour productivity gap vis-à-vis the United States and the manufacturing branch's employment performance (measured by whether it created or destroyed jobs), for Argentina, Chile and Mexico, respectively. Each table is constructed as a matrix, in which the upper left quadrant identifies the industries that are catching up with United States productivity standards while simultaneously creating new jobs; the upper right quadrant lists industries that are similarly converging with the United States, but which are reducing their absolute employment level; the lower left quadrant identifies industries that are lagging behind the United States but creating new jobs; and, finally, the lower right quadrant shows industries that are both lagging behind the United States and destroying positions.

Weighting the relative significance of the various industrial sectors with their share in industrial output at the end of the period under consideration indicates that roughly $70 \%$ of Argentine manufacturing production was gradually catching up with United States productivity standards while simultaneously contracting employment in absolute terms. This strongly confirms the argument that in the case of Argentina, convergence is more closely associated with labour displacement than with a high growth rate of manufacturing output. Only $20 \%$ of Argentina's industrial output was produced in industries that were simultaneously catching up with international productivity standards and creating new jobs -and it is precisely this combination that is the most valuable, as the narrowing of the gap involves genuine technical progress rather than simply worker displacement at the factory level. For example, the entire Argentine metalworking industry (sectors $381,382,383,384$ and 385 of the ISIC) was situated in the upper right quadrant, indicating that it was doing relatively better than its United States counterpart in terms of labour productivity growth, but that it was doing so as a result of a deep reduction in employment. In fact, the Argentine metalworking industry suffered a contraction of its labour force of well over 100,000 workers during the period under examination.

The situation in Chile is clearly different. Only $12 \%$ of Chilean manufacturing output was generated by industries in which the relative productivity gap was being reduced vis-à-vis the United States at the same time that workers were being dismissed in absolute terms. Conversely, 33\% of Chilean manufacturing production combined convergence and job creation.

22. On the impact of the reforms on employment, see Weller (2000). 
Table V.1

\section{ARGENTINA: RELATIVE LABOUR PRODUCTIVITY GAP AND JOB CREATION BY MANUFACTURING SECTOR, 1970-1996a}

\begin{tabular}{|c|c|c|}
\hline & GENERATE EMPLOYMENT & REDUCE EMPLOYMENT \\
\hline $\begin{array}{l}\text { Industries that are } \\
\text { catching up }\end{array}$ & $\begin{array}{l}\text { 311: Foodstuffs } \\
\text { 321: Textiles } \\
\text { 332: Furniture } \\
\text { 342: Printing } \\
\text { 351: Chemicals } \\
\text { 352: Other chemicals } \\
\text { 353: Oil refining } \\
\text { 355: Rubber products } \\
\text { 371: Iron and steel }\end{array}$ & $\begin{array}{l}\text { 354: Coal products } \\
\text { 362: Glass } \\
\text { 369: Other non-metallic minerals } \\
\text { 372: Non-ferrous metals } \\
\text { 381: Metal products } \\
\text { 382: Non-electrical machinery } \\
\text { 383: Electrical machinery } \\
\text { 384: Transport equipment } \\
\text { 385: Professional scientific } \\
\quad \text { instruments }\end{array}$ \\
\hline $\begin{array}{l}\text { Industries that are } \\
\text { falling behind }\end{array}$ & $\begin{array}{l}\text { 313: Beverages } \\
\text { 314: Tobacco } \\
\text { 322: Apparel } \\
\text { 323: Leather products } \\
\text { 324: Footwear } \\
\text { 331: Wood products } \\
\text { 341: Paper and cellulose }\end{array}$ & $\begin{array}{l}\text { 356: Plastic products } \\
\text { 361: Ceramics } \\
\text { 390: Other manufactures }\end{array}$ \\
\hline
\end{tabular}

Source: Author's compilation, on the basis of the Programme for the Analysis of Industrial Dynamics (PADI), Economic Commission for Latin America and the Caribbean (ECLAC), Santiago, Chile.

a/ The numbers correspond to International Standard Industrial Classification (ISIC) categories.

The differences in the distribution of the two countries' industrial branches within the matrix is consistent with the structural adjustment model presented in Chapter II, which positioned Argentina and Chile in distinct phases of adjustment following the implementation of the structural reforms. Chile is the only country in the region to date that has managed to return to an equilibrium macroeconomic growth path following the debt crisis of the early 1980s. In the 1990s, savings and investment returned to pre-crisis levels, and many new manufacturing plants were erected. The overall rate of growth increased significantly, as did the demand for labour, after a dramatically high rate of unemployment-close to $22 \%$ - in the early 1970 s when the reforms actually started. 
Table V.2

\section{CHILE: RELATIVE LABOUR PRODUCTIVITY GAP AND JOB CREATION BY MANUFACTURING SECTOR, 1970-1995}

\begin{tabular}{|c|c|c|}
\hline & GENERATE EMPLOYMENT & REDUCE EMPLOYMENT \\
\hline $\begin{array}{l}\text { Industries that are } \\
\text { catching up }\end{array}$ & $\begin{array}{l}\text { 331: Wood products } \\
\text { 341: Paper and pulp } \\
\text { 369: Other non-metallic minerals } \\
\text { 371: Iron and steel } \\
\text { 372: Non-ferrous metals } \\
\text { 381: Metal products }\end{array}$ & $\begin{array}{l}\text { 342: Printing } \\
\text { 351: Chemicals } \\
\text { 353: Oil refining } \\
\text { 362: Glass }\end{array}$ \\
\hline $\begin{array}{l}\text { Industries that are } \\
\text { falling behind }\end{array}$ & $\begin{array}{l}\text { 313: Beverages } \\
\text { 323: Leather products } \\
\text { 324: Footwear }\end{array}$ & $\begin{array}{l}\text { 314: Tobacco } \\
\text { 321: Textiles } \\
\text { 355: Rubber products } \\
\text { 382: Non-electrical } \\
\text { machinery } \\
\text { 383: Electrical machinery } \\
\text { 384: Transport equipment } \\
\text { 385: Professional scientific } \\
\text { instruments } \\
\text { 390: Other manufactures }\end{array}$ \\
\hline
\end{tabular}

Source: Author's compilation, on the basis of the Programme for the Analysis of Industrial Dynamics (PADI), Economic Commission for Latin America and the Caribbean (ECLAC), Santiago, Chile.

a/ The numbers correspond to International Standard Industrial Classification (ISIC) categories.

The Argentine case is somewhat different. The investment rate plummeted from $22 \%$ to less than $10 \%$ in the early 1980 s. The economy entered a long stagflation period, with open unemployment coming close to $20 \%$. Although recovery (phase II) started in the first half of the 1990s, investment in new production facilities never reached the levels seen in Chile throughout the 1990s. Businesses maintained a defensive attitude, and animal spirits remained low in the face of the macroeconomic uncertainty caused first by the Asian crisis and then by the Russian and Brazilian ones. Under such circumstances, labour productivity continued to grow at the plant site, but mostly as a result of labour-saving changes being introduced in old manufacturing facilities. Production processes were farmed out and labour continued to be dismissed at the firm level, while the stagnant macroeconomic context prevented these same workers from being reabsorbed elsewhere in the economy.

This analysis reveals the micro-to-macro nature of the problem, and it explains why Chile and Argentina present such major differences in job creation. In the Argentine adjustment process, large increases in labour 


\section{MEXICO: RELATIVE LABOUR PRODUCTIVITY GAP AND JOB CREATION BY MANUFACTURING SECTOR, 1970-1994a}

\begin{tabular}{lll}
\hline & GENERATE EMPLOYMENT & REDUCE EMPLOYMENT \\
\hline Industries that are & 323: Leather products & 311: Foodstuffs \\
catching up & 331: Wood products & 322: Apparel \\
332: Furniture & 342: Printing \\
341: Paper and pulp & 354: Coal products \\
355: Rubber products & 356: Plastic products \\
& 361: Ceramics & 383: Electrical machinery \\
362: Glass & 390: Other manufactures \\
369: Other non-metallic minerals & \\
371: Iron and steel & \\
372: Non-ferrous metals & \\
381: Metal products & \\
384: Transport equipment & \\
& \\
313: Beverages & \\
314: Tobacco & \\
321: Textiles & \\
324: Footwear & \\
351: Chemicals & \\
352: Other chemicals & \\
353: Oil refining & \\
\hline
\end{tabular}

Source: Author's compilation, on the basis of the Programme for the Analysis of Industrial Dynamics (PADI), Economic Commission for Latin America and the Caribbean (ECLAC), Santiago, Chile.

a/ The numbers correspond to International Standard Industrial Classification (ISIC) categories.

productivity are the flip side of high structural unemployment. Chile is much closer to macroeconomic equilibrium, which led many new firms to enter the economy and subsequently improved employment absorption.

Mexico lies somewhere between Argentina and Chile. Some 37\% of Mexican manufacturing output was generated by industries that were closing the labour productivity gap with the United States while simultaneously creating new jobs, and $30 \%$ of industrial output can be traced to sectors that managed to close the labour productivity gap but reduced employment in absolute terms. 
Like Argentina, Mexico was in phase II of its macroeconomic adjustment process throughout the 1990s. From that perspective, the fact that Mexico attained low manufacturing investment in that decade reflects both the perceived inconsistency of its macroeconomic adjustment programme and the appreciation of the local currency prior to the 1994 devaluation. So far the Mexican example resembles the case of Argentina in that it featured weak employment generation in the context of the rationalization of old production facilities and the dismissal of labour. The unemployment rate never reached the dramatic levels of Argentina, however, largely because of a single factor: namely, the maquiladoras. The strong boost given by the Mexican authorities to the maquila sector led many United States, Japanese and Korean firms to install new production capacity in Mexico to cater to the rapidly expanding United States market. These new plants absorbed most of whatever new industrial investment Mexico attained during the 1990s. Nearly $50 \%$ of the new jobs created in Mexico in the 1990s were in the maquila sector. The Mexican case thus combines the dismissal of labour in a large number of industrial activities with job creation in the maquila sector -albeit at much lower rates per hour.

Other countries in the region, particularly Brazil, Colombia and Uruguay, seem to be closer to the case of Argentina, which points to the real weakness of the new Latin American economic model in relation to employment creation. Workers are dismissed at the factory level and labour productivity improves, but these workers cannot find jobs elsewhere in the economy, given the prevailing macroeconomic uncertainty and the resulting low rate of economic growth and limited investment in new production facilities. Chile seems to be the exception in this respect.

\section{B. The Relative Labour Productivity Gap Between Small and Large Firms}

Small and medium-sized enterprises have had more difficulties adapting to the new market-oriented policy regime than large domestic conglomerates or local subsidiaries of transnational corporations. Numerous SMEs exited the market following the recent trade liberalization and market deregulation efforts, as a result of asymmetric information and imperfect access to factor markets, in particular long-term capital markets and markets for technology. This process was particularly marked in labour-intensive sectors such as furniture, clothing and leather and footwear, as well as in engineering-intensive sectors such as machine tools and agricultural machinery, in which familyrun SMEs usually predominate.

In Chile, for example, almost $40 \%$ of the manufacturing plants that exited the market after the economy was opened up in the 1970s and early 1980s produced labour-intensive goods such as footwear, clothing and furniture. 
Table V.4

500 LARGEST FIRMS IN LATIN AMERICA, 1990-1992, 1995 AND 1998

\begin{tabular}{lccr}
\hline TYPE OF FIRM & $1990-1992$ & 1995 & 1998 \\
\hline Number of firms & 500 & 500 & 500 \\
Private national & 265 & 279 & 258 \\
Foreign & 142 & 154 & 202 \\
Public & 93 & 67 & 40 \\
Sales (billions of dollars) & 360.1 & 558.6 & 646.4 \\
Private national & 138.4 & 233.2 & 272.9 \\
Foreign & 95.8 & 164.9 & 250.1 \\
Public & 126.0 & 160.5 & 123.4 \\
Share of total sales for the 500 (\%) & 100.0 & 100.0 & 100.0 \\
Private national & 38.4 & 41.8 & 42.2 \\
Foreign & 26.6 & 29.5 & 38.7 \\
Public & 35.0 & 28.7 & 19.1 \\
Sectoral distribution (billions of dollars) & 360.1 & 558.6 & 646.4 \\
Primary sector & 100.1 & 140.2 & 112.4 \\
Manufacturing & 152.1 & 241.6 & 267.9 \\
Services & 107.9 & 176.8 & 266.0 \\
Sectoral share of total sales for the 500 (\%) & 100.0 & 100.0 & 100.0 \\
Primary sector & 27.8 & 25.1 & 17.4 \\
Manufacturing & 42.2 & 43.3 & 41.4 \\
Services & 30.0 & 31.6 & 41.2 \\
\hline
\end{tabular}

Source: Division of Production, Productivity and Management of the Economic Commission for Latin America and the Caribbean (ECLAC), Foreign Investment Unit, on the basis of information provided by América Economía.

Another 20\% pertained to metalworking industries producing capital goods and consumer durables. SMEs were clearly prominent in both areas. In contrast, local subsidiaries of transnational firms and domestically owned conglomerates adapted well to the new economic policy regime, and they captured an increasing share of GDP. (Tables V.4 and V.5 show results for the region as a whole).

Although globally SMEs are losing ground within GDP, there are considerable inter-industry differences in relation to their relative labour 
Table V.5

100 LARGEST INDUSTRIAL FIRMS IN LATIN AMERICA, 1990-1992, 1995 AND 1998

\begin{tabular}{lrrr}
\hline TYPE OF FIRM & $1990-1992$ & 1995 & 1998 \\
\hline Number of firms & 100 & 100 & 100 \\
Private national & 50 & 51 & 52 \\
Foreign & 46 & 48 & 47 \\
Public & 4 & 1 & 1 \\
Sales (billions of dollars) & 101.4 & 165.7 & 182.0 \\
Private national & 42.6 & 69.6 & 69.3 \\
Foreign & 53.6 & 91.9 & 110.5 \\
Public & 5.2 & 4.2 & 2.2 \\
Share of total sales for the 100 (\%) & 100.0 & 100.0 & 100.0 \\
Private national & 42.0 & 42.0 & 38.1 \\
Foreign & 52.8 & 55.5 & 60.7 \\
(Automobile industry) & $(25.1)$ & $(29.0)$ & $(30.4)$ \\
Public & 5.2 & 2.5 & 1.2 \\
\hline
\end{tabular}

Source: Division of Production, Productivity and Management of the Economic Commission for Latin America and the Caribbean (ECLAC), Foreign Investment Unit, on the basis of information provided by América Economía.

productivity performance vis-à-vis large industrial firms. Table V.6 shows the breakdown for the Chilean manufacturing sector, comparing the relative labour productivity growth performance of small firms (10-50 employees) and large companies (more than 51) in 23 branches at the three-digit level of the ISIC. In 12 industrial branches, the relative productivity gap between small and large firms tended to fall; it remained virtually the same in four industries and tended to grow in the remaining seven cases.

To explore this mixed inter-industry response, the data were disaggregated to the four-digit level of the ISIC, so as to reduce the degree of heterogeneity within each branch. This was followed by an analysis of the cross-section statistical relation of the relative labour productivity gap between SMEs and large companies with three variables: (i) the growth rate of the industry; (ii) the average increase in the industry's skill level, as measured by the increase in the numbers of engineers and technicians employed by the industry; and (iii) the average increase in the industry's capital per worker, as measured by the per capita accumulated investment over the whole period (1979-1995).

Table V.7 shows the simple correlation coefficients between these variables. $R G$ represents the relative labour productivity gap between SMEs and large firms; GVP is the growth rate of output; IL is the accumulated investment per worker throughout the period; and S/US is the variation in the proportion of 


\section{Table V.6 \\ CHILE: LABOUR PRODUCTIVITY DIFFERENCES BETWEEN SMALL AND LARGE FIRMS, 1979-1995}

ISIC GROUP ${ }^{\mathrm{a}}$

ReLATIVE GAP BETWEEN SMALL AND LARGE FIRMS ${ }^{b}$

Manufacturing branches in which small firms

closed the relative labour productivity gap

with large firms

1.60

313: Beverages

1.23

321: Textiles

1.22

324: Footwear

1.43

331: Wood products

1.14

332: Furniture

1.63

351: Chemicals

1.54

356: Plastic products

1.22

369: Other non-metallic minerals

1.25

361: Ceramics

1.55

381: Metal products

1.22

384: Transport equipment

2.13

Manufacturing branches which recorded no

significant variations

314: Tobacco

1.00

322: Apparel

0.96

323: Leather products

1.03

342: Printing and publications

0.97

Manufacturing branches in which small firms

lost ground to large firms

341:Paper and cellulose

0.70

352: Other chemicals

0.84

355: Rubber products

0.70

362: Glass

0.65

382: Non-electrical machinery

0.89

383: Electrical machinery

0.79

385: Professional scientific instruments

0.88

Source: Author's calculations, on the basis of data from the National Statistics Institute.

a/ International Standard Industrial Classification.

b/ Labour productivity of small and medium-sized firms divided by the productivity of large firms. 
Table V.7

\section{CHILE: INTER-INDUSTRY CORRELATION MATRIX, 1979-1995}

\begin{tabular}{lcccc}
\hline & $\mathrm{GVP}^{\mathrm{a}}$ & $\mathrm{RG}^{\mathrm{b}}$ & $\mathrm{IL}^{\mathrm{c}}$ & $\mathrm{S} / \mathrm{US}^{\mathrm{d}}$ \\
\hline $\mathrm{GVP}^{\mathrm{a}}$ & 1.00 & 0.41 & 0.06 & -0.11 \\
$\mathrm{RG}^{\mathrm{b}}$ & 0.41 & 1.00 & 0.15 & -0.19 \\
$\mathrm{IL}^{\mathrm{c}}$ & 0.06 & 0.15 & 1.00 & -0.21 \\
$\mathrm{~S} / \mathrm{US}^{\mathrm{d}}$ & -0.11 & -0.19 & -0.21 & 1.00 \\
\hline
\end{tabular}

Source: Author's calculations, on the basis of data from the National Statistics Institute.

a/ Growth rate of the gross value of production.

$\mathrm{b} /$ Relative labour productivity gap between small and medium-sized firms and large companies.

c/ Accumulated investment.

d/ Variation in the proportion of skilled and unskilled labour in each industry.

skilled and unskilled workers in each industry. Working at the four-digit level provided 88 observations in the cross section regressions, and a correlation index equal to or larger than 0.40 is statistically significant at the $95 \%$ level.

The regression analysis indicates that SMEs performed relatively better than large firms in those industries that tended to grow faster than average. The other two variables do not appear to be significant, suggesting that the growth rate of each sector constitutes an overriding force influencing the relative performance of SMEs. In other words, a rapidly increasing aggregate demand facilitates the successful market insertion of SMEs. Access to factor markets -e.g., long-term capital, technology, qualified human resourcesprobably becomes easier when new opportunities open up at a faster pace as a result of rising growth. Access is probably much tighter in production sectors that are languishing or stagnant.

The structural reforms thus seem to have had a particularly damaging impact on SMEs, since the large majority of firms exiting the market belong in this group. But there seems to be an interesting inter-industry pattern of differences in this respect: in those industries that experienced a rapid expansion of demand (and output), SMEs tended to perform well relative to large firms. By contrast, the relative position of SMEs tended to deteriorate in those industries that grew slower than the sectoral average.

\section{Towards a Chronic Trade Balance Deficit in Manufacturing?}

Table V.8 outlines the trade balance in manufacturing for seven countries in the region in the period 1970-1996. The data show, first, that the trade deficit 


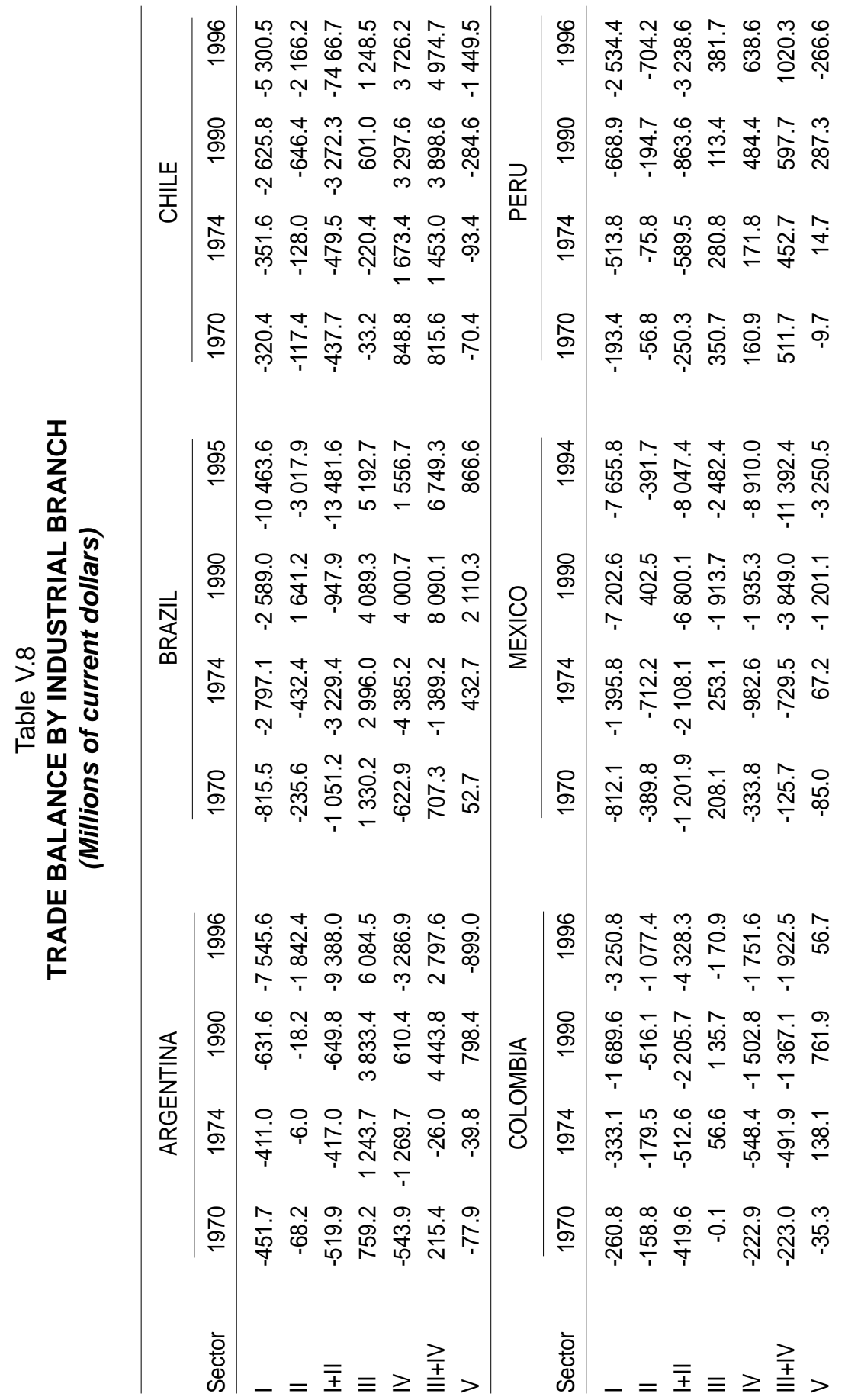




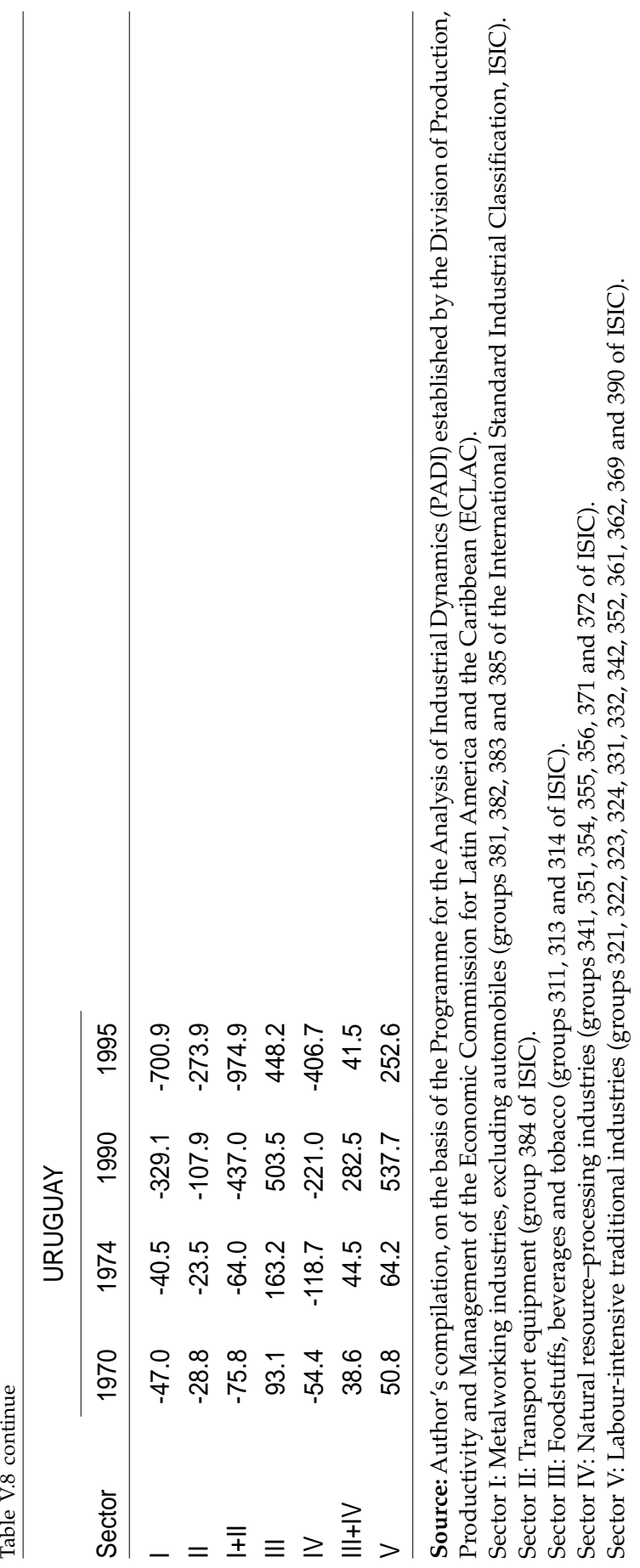


in manufacturing is increasing over time. Second, this is intrinsically linked to the fact that all of the countries in the region have now become heavy importers of capital goods, as well as of intermediate parts and components for industry, while they have concentrated in exporting either low value-added industrial commodities (Argentina, Brazil, Chile and Uruguay) or maquiladora output (Mexico). The engineering-intensive metalworking industries (Sector I) and the labour-intensive wage good industries (Sector V) have clearly fallen behind in terms of productivity and have become relatively heavy importers. It is in these industries that the region's countries are now finding it increasingly difficult to maintain a desirable trade balance, particularly as a result of a high elasticity of demand for imported capital goods and vehicles. In contrast, the natural resource-processing industries (sector III in the table) and agro-industry and foodstuffs production (sector IV) post positive balances, but they face a much lower elasticity of demand in world markets.

The data highlight one of the weakest points of the new Latin American economic model. The countries under examination have developed an intrinsically fragile external sector, wrought by the relative demise of the metalworking sector and the contraction of local capital goods production, on the one hand, and by the strong specialization in low value-added industrial commodities, on the other. In fact, the Latin American economies have specialized in goods for which foreign demand is growing far too slowly or on which industrial countries impose heavy trade restrictions, such as agroindustrial products. At the same time, they have become enthusiastic importers of capital goods which they used to produce domestically but which have fallen behind international best practices. This reveals a clear long-term structural weakness of the new economic model.

Is this a new Achilles' heel threatening the long-term sustainability of the Latin American model? The sharp differences between Mexico and the South American countries -especially Argentina, Brazil and Uruguay- are worth noting here. Because of the spectacular growth of Mexico's maquila exports in recent years (currently $50 \%$ of total exports), the Mexican external sector poses a somewhat different set of questions than that of the commodities-exporting countries, and the cases have to be analysed differently. Of particular concern is the issue of wages in the maquila industry. If Mexico is to continue to compete in international in-bond assembly, it must pay the high price of setting wages for maquiladora workers at a small fraction of wages in more developed industrial countries, certainly well below what is needed for developing strong domestic markets based on consumer purchasing power. Mexican wages must be competitive with those of China or Vietnam in order to continue to attract investment from maquiladora owners. Whether this is really a good long-term option for the Mexican society remains open for future discussion.

This analysis of certain aspects of the current Latin American economic model has identified several major new problems that will require attention 
in the near future: structural unemployment, the relative labour productivity gap between SMEs and large firms and the long-term fragility of the foreign trade balance in manufactures. The Latin American economies urgently need to develop a new policy agenda in all three areas if they are to succeed in their quest for more liberalized, deregulated macroeconomic policy regimes. Part three of the book examines the possible content of such an agenda. 


\section{Part Three \\ TOWARDS A NEW POLICY AGENDA}





\section{CHAPTER VI}

\section{THE INSTITUTIONAL AND TECHNOLOGICAL ENVIRONMENT FOR THE CURRENT DEBATE ON A NEW POLICY AGENDA}

This part of the book -chapters VI and VII- is devoted to policy issues related to the features of the Latin American economic model identified in previous chapters. If the long-term sustainability and political legitimacy of the current growth paradigm are to be maintained, labour productivity has to grow faster and the benefits of the transition to a more open, deregulated economy need to be better distributed among the various groups in society. The invisible hand has already done its share. Countries must now complement that process with the visible hand of Government and the synergies of collective action on the part of civil society.

Four main sets of constraints condition what can and should be done in the near future: (i) the new efficiency and equity problems the countries of the region developed in the 1990s, including increased structural unemployment (particularly in the Southern Cone economies) and lack of opportunities for SMEs; (ii) the new international competitive disciplines that emerged from the 1994 Uruguay Round of the General Agreement on Tariffs and Trade (GATT); (iii) the fragility of domestic technological capabilities in relation to the urgent requirements for innovation in the region; and (iv) the pro-market ideology now prevailing in the region, which makes it especially difficult to address issues of market failure and the subsequent need for intervention. All four elements inform the current debate on what needs to be done in the future and what Governments want to do to increase production and productivity and promote technological modernization and innovation. 
This chapter examines the present institutional environment; chapter VII then discusses a possible policy agenda for the future.

\section{A. The New International Trade Disciplines}

The new trade disciplines to which Latin American countries must gradually adapt are clearly biased against their future growth prospects. They will nevertheless have to be taken into consideration when planning for growth. Many practices that were common in the past are simply no longer possible, and the region must now seek case-specific solutions to the new institutional constraints in which Latin American societies operate. Governments must now explore which options are still available within the present institutional framework.

The Uruguay Round was negotiated between 1989 and 1993, ending with the signing of the Final Act in 1994. This replaced the General Agreement of 1947 and successive rounds. The Uruguay Round went far beyond the Tokyo Round (1973-1979) in liberalizing trade and eliminating non-tariff barriers, with one clear bias: agriculture and foodstuffs, which did not received similar treatment to manufacturing activities. The Uruguay Round also imposed new restrictions in areas such as export subsidies, the treatment of foreign investment and intellectual property rights. It created a new international institution, the World Trade Organization (WTO), to oversee international trade relations, together with a dispute-settlement body to deal with unfair practices.

The Uruguay Round Agreement can be seen as part of a gradual process of normative harmonization among countries, in the context of a rapidly globalizing world economy. Such growing harmonization introduces a number of potentially damaging constraints for developing countries, but there always remains a certain amount of freedom for each country to maximize its own benefits while operating within the new rules. The bottom line seems to be understanding the new disciplines fully in order to operate within them.

Several issues should be examined from this perspective, including export subsidies, quotas or other physical restrictions on imports and local content requirements. The Uruguay Round introduced important changes in each of these areas. In the Tokyo Round, export subsidies were regulated in article 6 (on antidumping measures and reprisals) and article 16 of the General Agreement. These articles defined export subsidies and damage as a justification for reprisals on the part of the importing country. Both concepts were left ambiguous in the Final Act of the Tokyo Round, leaving room for debate. The Final Act of the Uruguay Round, in contrast, defined three types of subsidies: those that are explicitly forbidden, those that are actionable, and those that are non-actionable. Forbidden subsidies are those directly related to exports, such as the various forms of drawback that governments use to 
promote exports. This restriction does not apply to drawbacks on temporary imports of parts and components used in the production of export goods. Actionable subsidies are those that are unrelated to trade and are specific to certain industries or firms. These can affect export prices, and a signatory can appeal to WTO's dispute-settlement body if the subsidies damage domestic output. Damage is defined as serious if the ad valorem amount of the subsidy exceeds the value of production in the importing country by $5 \%$. In these cases, the burden of proof lies with the exporting country. Several such cases have been challenged in court, including, for example, seamless tubes and salmon. Consequently, a rich body of experience is accumulating on how to defend exporters in developing countries against allegations of dumping, which normally amount to a disguised attempt by industrialized countries to protect firms unable to meet the competitive pressure of new, more efficient producers. Now that some firms in developing countries have converged with the international productivity frontier, less efficient suppliers located in industrialized societies are bringing them to court to stop their competitive entry.

Non-actionable subsidies are those of a general nature that have no direct impact on export prices. They include subsidies for research and development activities, environmental protection and special assistance for underdeveloped regions. ${ }^{23}$

Countries have eight years, extendible to ten, to eliminate prohibited subsidies. In the case of actionable subsidies, the importing country must show serious damage to its production structure before the new trade rules are applied to the exporting country.

With regard to foreign direct investment, the Trade-Related Investment Measures (TRIMs) prohibit anything that is inconsistent with the fundamental 'spirit' of the Agreement. In particular, foreign and local firms are guaranteed equal treatment, and domestic content requirements are gradually to be eliminated.

The Agreement on Trade-Related Intellectual Property Rights (TRIPs) introduces new institutions deriving from the International Paris Convention of 1863 on intellectual property rights, patents and trademarks. The international regulatory body in this case is World Intellectual Property Organization (WIPO), which ensures that national and foreign firms receive equal treatment in relation to the protection of property rights on knowledgegeneration activities and innovation. Patent rights should be similar in different areas of the economy -whereas previously pharmaceutical and health-related products were treated separately-and the protection of property rights should not depend on the domestic use of the relevant know-how.

23. The so-called Annex VII countries are exempt from the obligation to eliminate prohibited subsidies, on the basis of extreme poverty. These include, from Latin America and the Caribbean, Bolivia, the Dominican Republic, Guatemala and Nicaragua. 
The TRIPS Agreement has important ramifications for the pharmaceuticals industry, in particular. The pharmaceutical industry's lobby is clearly behind recent changes in the national patent law of many Latin American countries, including Argentina, Brazil, Chile and Mexico. These laws seek to restrict competition from local SMEs that copy the formula for pharmaceutical raw materials early in the production cycle, thus challenging the market position of large multinational corporations owning the original molecules. ${ }^{24}$

Many of the institutions now regulating international trade are far from beneficial to relatively less developed countries, while these countries have obtained very few concessions in areas of great importance for their future growth. It should be pointed out, however, that there is a significant degree of freedom as to how each country interprets the new disciplines locally. Hence the importance of countries learning about all the nuances of the regime in order to take full advantage of the new institutional arrangements. This domestic learning process will be a key factor in determining how and to what extent each country can protect itself and benefit from the new institutional environment prevailing at the world level.

\section{B. The Fragility of Domestic Innovation}

Domestic technological capabilities, as well as the structure and behaviour of national innovation systems, have changed significantly as a result of the recent structural reforms. Together with the new institutional environment established by the Uruguay Round of the GATT, each country's new institutional environment for technology generation and diffusion will certainly condition further improvements in efficiency and equity.

24. Because many Latin American and Caribbean countries based their pharmaceutical patent laws on eighteenth century Spanish legislation, they only recently began to grant product patents in this field, as opposed to process patents. The lack of process patents led to the rapid growth of national pharmaceutical industries in the postwar period. In Argentina, Brazil and Mexico, for example, local firms were able to displace multinational corporations from the domestic market in ethical products by copying ingredients developed by the multinationals, because domestic legislation that did not protect the patentability of pharmaceuticals. The same occurred many years earlier in Italy, Japan and Switzerland, which violated the Paris Convention for decades (Penrose, 1951). In Latin America and the Caribbean, however, pressure from transnational industry (especially the United States) forced a change in the patent laws, such that products could be patented as well as processes. This substantially consolidated the market position of big international laboratories to the detriment of local manufacturers of pharmaceutical specialities and active principles. The role of the U.S. Pharmaceutical lobby on the U.S. Trade Department has been documented by different authors, such as Mary Olson from Washington University. See her CERP Publication 249 "Political influence and the development of U.S. regulatory policy: The 1984 drug legislation". The impact of the above on the Latin American pharmaceutical industry has been examined in Katz (1997). 
Market organization and microeconomic behaviour related to innovation, $R \& D$ activities and the generation and utilization of technical knowledge in production activities have changed dramatically since the "inward-oriented" ISI period. Many knowledge-generation activities have disappeared, to be replaced by others that are more in line with the new production structure. Public and private R\&D labs and departments were closed, or their agendas, aims and constraints significantly changed, following the privatization of major fields in the economy. This process clearly conditions what it is possible and desirable in terms of the future expansion of national innovation capabilities and knowledge-generation efforts.

\section{Innovation Efforts during the Import Substitution Period}

Latin American countries historically have not been strong spenders in R\&D activities. They have rarely surpassed $0.5-0.7 \%$ of GDP (slightly higher in some countries recently), whereas many developed countries and some of the Asian nations spend 1.5\%-2.5\%. Furthermore, fully $90 \%$ of the region's R\&D expenditure was traditionally carried out in public firms, universities and technology institutes and laboratories. The remaining $10 \%$ was carried out by the private sector, either by local subsidiaries of transnational corporations, large domestically owned conglomerates or local SMEs. This section briefly reviews some of the more prominent features of the innovation system that developed in Latin America under the inward-oriented industrialization model, in order to provide a point of reference for evaluating the changes wrought by the structural reforms.

During the Second World War and in the early 1950s, each of the Latin American countries developed a strong sector of public enterprises responsible for the production of goods and services in fields such as telecommunications, energy and transport and in defence-related industries such as iron and steel, aluminium or petrochemicals. These production activities demanded not only new production facilities -which were sometimes purchased on a turnkey basis from international subcontractors- but also a steady flow of new technologies and engineering services which had to be developed on site. Many countries therefore created R\&D departments and project-design groups for the purpose of generating new knowledge and adapting imported technologies to the local circumstances. As part of this State-led process, some countries developed sophisticated know-how in frontier fields, such as nuclear technology in Argentina and aeronautics in Brazil. Such developments were to become important in the technological evolution of these countries many years after the original start up of these activities. Thus in just two decades, many of the region's countries developed a vast State-led scientific and technological infrastructure, laying the foundations of their future national innovative system. 
During the ISI period, two types of firms carried out local R\&D and engineering activities, with distinct behaviour in knowledge generation and knowledge utilization: transnational corporations and domestic SMEs. Consider first the case of the local subsidiaries of large multinational corporations. A large number of foreign firms entered the Latin American countries right after the Second World War. These firms brought with them new production and process technologies, as well as methods of production organization that were often unknown locally. Their local activities had a profound impact on the industrial culture of the time: they introduced working habits, quality control guidelines, labour norms and standards methods for upgrading suppliers and forms of subcontracting that were unfamiliar to the local firms.

Although transnational corporations did not come to the region with the explicit aim of developing local technological capabilities, they often ended up doing so in practice. Given the firm-specific nature of technology as a factor of production, and the need to adapt it to the specific circumstances that surround its utilization in a particular production facility, many of these firms were obliged to create engineering departments, as well as groups capable of providing technical assistance to production engineers, in order to operate efficiently in the local environment.

The technological efforts undertaken by such firms did not so much seek to generate new products or production processes as to adapt to local conditions the product specifications, process technologies and production organization routines that were originally developed by the parent companies for their home markets. They also sought to use raw materials that were available locally. The technological efforts of this group of firms can thus be seen as adaptive. They were not particularly interested in developing knowhow aimed at enhancing their exports possibilities, since most of them were exclusively geared towards the domestic market.

The second broad group of firms contributing to technological innovation in the region comprised small and medium-sized enterprises. A large number of SMEs developed in the region in the immediate post-war years, when tariff protection and subsidized public credit stimulated the formation of thousands of family enterprises producing textiles, garments, footwear, machine tools, equipment for the foodstuffs industry, furniture, agricultural machinery and so forth. Many of these firms managed to grow rapidly during the 1950s and 1960s, in step with aggregate demand. Although many entered the market on the basis of self-designed and sometimes quasi-artisan products and production facilities, they gradually developed technological and engineering capabilities which allowed them to significantly improve their plant layout, product design engineering and production organization technologies. Many of these firms designed and even constructed their own machinery and equipment (Katz, 1974, 1982). It is quite clear that they underwent a highly 
idiosyncratic, long-term learning process. Unlike the subsidiaries of foreign firms, SMEs created product and process technologies without any prior support from abroad, apart from the simple copying of foreign technology and the technical training that many immigrant entrepreneurs brought with them from their home countries. Perhaps this explains why many industries underwent a process of convergence with the international productivity frontier long before the recent market-oriented structural reforms. Domestic learning processes and the development of domestic technological capabilities were clearly present during the import substitution period, with many domestic firms advancing along their long-term learning curve. Nevertheless, only rarely did they develop innovative products and production processes that had repercussions beyond national borders (Katz, 1987).

Local SMEs thus constituted another important component of the national innovative system in the ISI period. They developed a technological 'culture' based on copying foreign technology and adapting it to local needs, in the context of imperfect information, inadequate access to world markets for equipment and machinery and scant competitive pressure in their home markets.

\section{Post-reform Changes in National Innovation Systems and Technological Capabilities}

The structural reforms, on the one hand, and the gradual transition to a world of real-time, computer-based production organization, on the other, are dramatically changing the structure and performance of the region's innovation systems, together with the role of domestic technological capabilities as a source of productivity growth. Some R\&D and engineering activities are no longer necessary, because knowledge can be obtained on-line from foreign suppliers. Privatized firms in the telecommunications, energy and transport sectors now rely on knowledge-generation activities carried out in their respective headquarters, and they do not undertake R\&D work of great significance locally. Imported capital goods are cheaper and more accessible today than in the past, leading many firms to replace them sooner than before and to eliminate in-house engineering efforts aimed at extending the life cycle of the available machinery. Consequently, the structure and behaviour of the innovation system and the dynamics of the creation and destruction of domestic technological capabilities are changing markedly.

The innovative system of the 1990s engaged the active influence and participation of many new foreign firms that had recently entered the economy either through the privatization of public utilities or through mergers and acquisitions of domestic firms. The countries in the region thus moved towards a more complex production structure, which is closer to international 
productivity standards, but which is less intensive in the use of local technical knowledge and engineering services. This represents an important structural fragility in the process of moving from simple, standardized commodities towards goods and services with higher value added. The paradox of achieving a more complex, closer-to-the-frontier production structure at the cost of a weaker, more fragile national innovation system is a critical feature of the new Latin American economic model, which must be taken into account in the new policy agenda.

The final chapter of the book discusses the contents of a policy agenda for the future. 


\section{CHAPTER VII \\ TOWARDS A NEW POLICY AGENDA}

The discussion has thus far centred on a macro-to-micro interpretation of the economic, institutional and technological transformation that the Latin American economies (and industries) have been going through over the last two decades. The recent market-oriented structural reforms accelerated this transformation, but they did not actually trigger it. Countries (and industries) were catching up with or lagging behind international productivity standards well before the implementation of the reforms. History matters, and the accumulated technological capabilities that the different countries (and industries) managed to attain during the import substitution industrialization period represent a key factor in explaining the reactions of different industries, regions and countries to major changes in the macroeconomic policy and institutional framework.

It cannot generally be argued that Latin American countries are doing much better today than in the past, although the region is clearly performing better in the macroeconomic fundamentals than during the inward-oriented ISI period. High inflation rates are a thing of the past, and nobody in the region today defends printing money as a way to stimulate the economy. The region as a whole is significantly more open to trade, although major differences seem to prevail in this respect between Mexico and the Central American economies, on the one hand, and some of the South American countries -namely, Argentina, Brazil and Uruguay- on the other, in that the former has a considerably stronger export orientation than the latter. (Chile appears as an important exception within this group, as it now specializes in natural resource-based industries). Maquila industries, producing garments and electronic products for the United States market, seem to be the main 
explanation of the differences in export performance. Moreover, Latin American countries significantly increased their demand for foreign capital goods and parts for vehicles and machinery. The trade balance in manufacturing reveals a chronic, long-term deficit which opens up major policy questions for the future.

The differences in performance vis-à-vis the ISI period become disheartening on comparing indicators of productivity growth and equity in Latin American countries (and industries) during the market-oriented period (i.e., the 1990s) with their record in previous decades. The picture is highly heterogeneous among countries and scarcely satisfactory globally. Some countries have increased their productivity growth rate -in both manufacturing and non-manufacturing activities- and show evidence of gradually converging with international standards for labour productivity. In most of the cases in which this is happening, however, it is not the consequence of a faster growth rate under full-employment conditions, but rather the result of high rates of unemployment, certainly much higher than these same countries exhibited in the past. Individual firms and industries have displaced labour and improved their microeconomic performance, but the economy as a whole has not been capable of returning to a growth path that facilitates full employment. Other countries are not doing much better than during the ISI period, and they are gradually lagging behind the international productivity frontier. Because the United States increased labour productivity faster in the 1990s than in the past, a faster productivity growth rate alone was not sufficient for Latin American countries to close the productivity gap with world standards.

The available evidence is also disheartening with regard to equity. In a few cases-Chile, for example- the absolute number of poor households clearly fell, but this was not the case in the large majority of the countries in the region. Relative indicators of equity do not show clear signs of improvement, either.

Table VII.1 and figures VII.1 and VII.2 summarize these processes. The table uses six indicators to compare the economic performance of Latin America during the ISI period with that of the 1990s, a decade in which most of the region systematically attempted to introduce market-oriented liberal reforms. The table shows mixed results for the region as a whole: inflation rates were lowered and trade increased, but GDP growth and productivity fell and poverty increased. Figure VII.1, which plots individual country performance for GDP growth, illustrates that only a handful of countries in the region grew faster in the 1990s than in the 1945-1980 period. The majority have not been able to recover the pace of growth enjoyed before the debt crisis of the 1980s. Figure VII.2 further indicates that only three countries (Argentina, Chile and Uruguay) have managed to increase productivity above pre-crisis levels. 
Table VII. 1

\section{LATIN AMERICAN PERFORMANCE INDICATORS, 1945-2000 (\%)}

\begin{tabular}{lcrrr}
\hline INDICATOR & $1945-1980$ & $1980-1990$ & $1990-2000$ & 2000 \\
\hline Annual inflation rate & 20.0 & 400.0 & 168.0 & 9.2 \\
Annual growth rate of exports (volume) & 2.1 & 4.4 & 9.4 & 11.1 \\
Annual growth rate of imports (volume) & 5.9 & -0.8 & 12.8 & 12.3 \\
Annual GDP growth rate & 5.6 & 1.2 & 3.3 & 4.3 \\
Per capita GDP growth rate & 3.1 & -1.8 & 1.6 & 2.2 \\
Poor households (\%) & 35.0 & 41.0 & 38.0 & 38.0 \\
\hline
\end{tabular}

Source: ECLAC, Equity, development and citizenship (LC/G.2071), Santiago, Chile, Economic Commission for Latin America and the Caribbean (ECLAC), 2000.

Figure VII.1

AVERAGE ANNUAL GDP GROWTH, 1945-2000

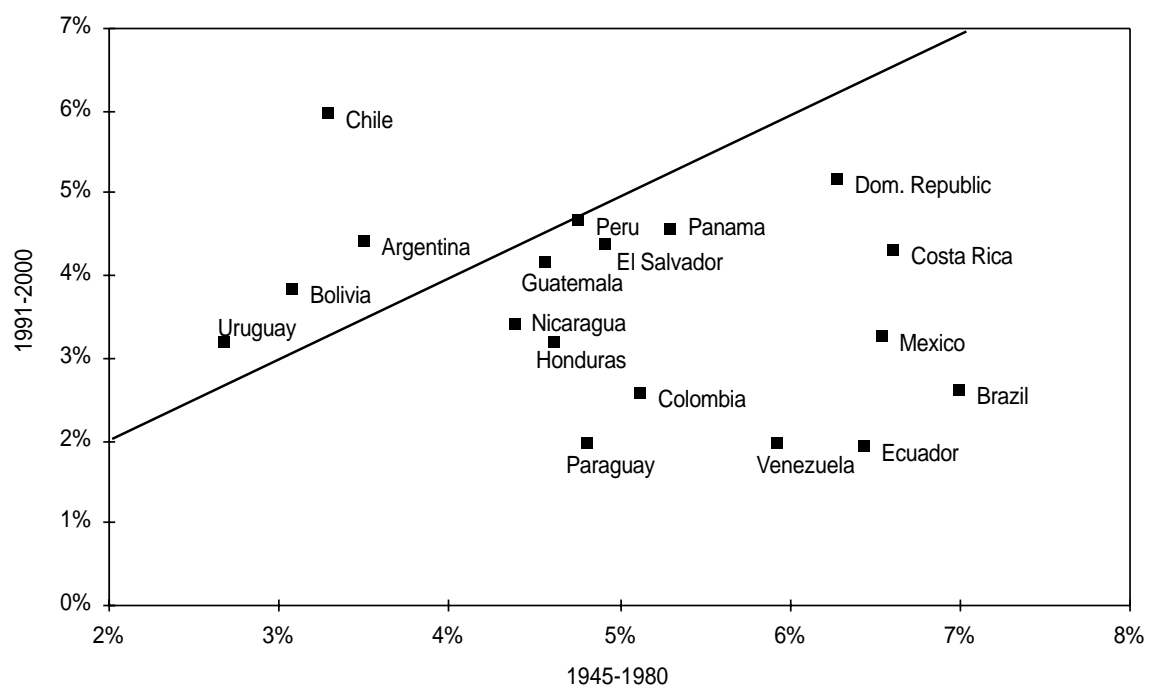

Source: ECLAC, Equity, development and citizenship (LC/G.2071), Santiago, Chile, Economic Commission for Latin America and the Caribbean (ECLAC), 2000. 
Figure VII.2

\section{AVERAGE ANNUAL GDP GROWTH PER WORKER, 1945-2000}

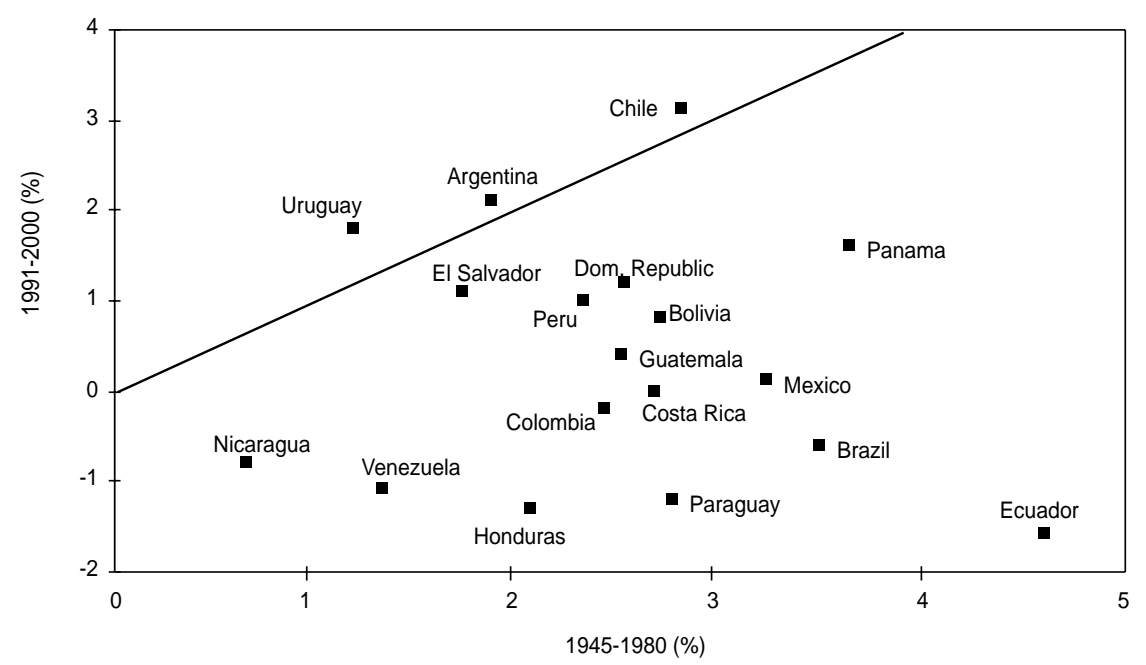

Source: ECLAC, Equity, development and citizenship (LC/G.2071), Santiago, Chile, Economic Commission for Latin America and the Caribbean (ECLAC), 2000.

Confronted with the above facts, mainstream economists argue that it is necessary to wait longer while continuing with the same policy package, such as privatizing those activities that have not yet been privatized and deregulating markets (labour markets, in particular). A minority of more heterodox economists considers that it is time to reform the reforms. ${ }^{25}$ While these economists acknowledge the importance of the macroeconomic fundamentals, they argue for introducing new policies that would foster better micro- and mesoeconomic interventions and improve efficiency and equity in the transition to a more open, deregulated policy regime. Imperfect factor markets, asymmetries in the access to information and technology, and externalities and synergies at the local level all indicate that this transition could be carried out more efficiently and equitably than strict laissez-faire principles have achieved to date.

I here joint ranks with those who argue that we need to reform the reforms. In that spirit, this chapter examines the main components of a new policy

25. The notion of reforming the reforms was first used by Ffrench-Davis (2000). 
agenda that would be capable of enhancing the region's productivity growth performance and its convergence with international productivity standards, while simultaneously improving the equity consequences of the transition to a more open, deregulated macroeconomic policy regime. The specific package will strongly depend on the theoretical preconception of the analyst regarding the relative role of markets and government as determinants of microeconomic behaviour. This, then, is the point of departure.

\section{A. Neoclassical and Evolutionary Perspectives on the Appropriate Policy Agenda}

As discussed in chapter I, neoclassical growth theory provides a highly stylized description of the forces that account for economic growth in modern capitalism, based on the notion of the representative firm (Solow, 1988). The firm is assumed to have perfect information and rational expectations about the future, as well as a perfect understanding of and free access to its production function. Factor markets supplying capital services and labour are similarly assumed to operate perfectly. Under such conditions, microeconomic behaviour is exogenously determined rather than influenced by contextspecific forces. Given this analytical background, mainstream economists advocate generic interventions that are incapable of capturing the complexity and specific characteristics of a country, region or industry. Opening up to foreign competition, deregulating and privatizing economic activity and factor markets, maintaining macroeconomic prices close to equilibrium and upholding property rights are thus presented as general prescriptions that are expected to work almost irrespectively of the place in which they are applied.

Contemporary history shows, however, that this is seldom the case. Consider, for example the recent example of the former Soviet Union, where the above-mentioned policy package was enforced under the a priori assumption that it would successfully develop the institutions of modern capitalism. Yet they did not. Failure to understand the idiosyncratic nature of a given society and economic environment can easily lead to wrong policy prescriptions capable of worsening even further the circumstances that needed to be changed. In other words, policy design and implementation must reflect the specific nature of each country, industry or region, together with in the coevolution of technological, institutional and economic forces.

The European discussion on technology and innovation constitutes a good example of this argument. Although the debate on these issues centres on the generic model of a market-oriented economy, the policy agenda implemented in each country is highly context specific and far from neutral or horizontal. Policies clearly reflect the enormous differences that prevail, for example, 
between France, Germany, Italy and the United Kingdom in relation to the relative role of markets and the State as determinants of long-term economic performance. Market relations tend to take precedence in the British debate, while in France the public sector maintains a central role in technological development and innovation. In Italy, local and municipal relationships are paramount, while in Germany, institutional functioning is strongly conditioned by a long history of agreements and commitments between the banking sector, firms and trade unions. These differences in market organization and the relative role of markets and Government explain why the national innovation systems function differently in each of the countries, why the various actors in the system -firms, universities, banks, trade unions, technical and vocational schools and so forth-form distinct patterns of interaction and why the countries display major differences in technological and innovative performance. Each of these four models of social organization prompts its own set of social routines, corporate strategies and governance rules, giving rise to very different forms of capitalism.

Understanding how a particular country behaves in the area of innovation and technological change thus constitutes a major prerequisite for the successful design and implementation of policies aimed at improving the longterm productivity performance of the country. The inward-oriented growth model that Latin American countries followed during the ISI period has been replaced in recent years by a market-oriented model in which subsidiaries of transnational corporations and large domestic conglomerates have gained relative participation in both GDP and the political arena. State companies have almost disappeared, and SMEs have lost participation in the production structure as a result of their limited ability to adapt to the new incentives.

After a long period in which policy makers followed the principle of the less intervention, the better, questions are now arising as to what kind of government (with regard to size and degree of regional decentralization, for example) can facilitate the institutional re-engineering efforts that must be undertaken. It is not just a matter of the State improving its technical and professional bodies, introducing incentives for them to work in the collective interest and limiting the space for corruption and arbitrariness. Rather, policy makers must forge new forms of cooperation and coordination between public agencies and the private sector, as they search for a new style of governance that is more conducive to growth than the approach that has thus far been followed in the region.

Different models of market organization and different mixes of publicprivate interaction clearly affect the way that each society manages the design and implementation of technological and innovation policies. Still pending in Latin America is a context-specific discussion of what it would take to apply a new policy package capable of enhancing innovation and raising the productivity growth rate in different countries of the region. In Chile, for 
example, trade liberalization policies stimulated the creation of a very dynamic business community, which is strongly concentrated in a few new areas of production: pulp and paper, minerals, fruit, salmon and fishmeal. Large domestic conglomerates have taken the lead in these fields, expanding quite rapidly over the last two decades through the construction of highly competitive manufacturing facilities. Many of these firms have recently decided to undertake direct investment projects in other countries of the region, notably Argentina and Peru, thereby capitalizing on the experience garnered in the course of their earlier expansion in Chile. These same firms, however, currently display little energy for confronting the new wave of domestic megamergers and acquisitions, and they are selling their domestic facilities to large multinationals (mostly Spanish) that are taking control of sectors like banking, fisheries and electricity services worldwide. Enhancing Chile's productivity growth and international competitiveness demands a context-specific examination of the Chilean situation, on the basis of which to design a set of policies that addresses the current economic, institutional and technological features of the Chilean environment. Roughly the same can be said for the other countries in the region. Indeed, all new technology and innovation policies should be founded on the specific context of each national situation, that is, the new policy agenda should be highly localized.

Finally, the implementation of new policies will be affected by uncertainty and the lack of prior information as to what works and what does not. It will thus be necessary to proceed by trial and error, experimenting with different policy actions and then identifying useful elements. Rather than looking for an optimum set of policies in advance, authorities should adopt a pragmatic attitude of selection under uncertainty.

\section{B. A New Agenda Addressing Issues of Production Efficiency and Equity}

This section examines three major areas of policy action, all of which require prompt attention if countries are to build up new institutions and develop new forms of interaction between the State and the private sector, capable of recreating a new social climate more conducive to growth. These areas are as follows: (i) the strengthening of regulatory actions in the recently privatized sectors of the economy, such as energy or telecommunications, which foster new forms of regulated competition with the aim of protecting consumers; (ii) competition policies capable of securing an adequate functioning of markets in the more concentrated business environment now prevailing in Latin American countries; and (iii) the creation of a national agency for innovation and competitiveness, responsible for horizontal, sectoral and regional policies that enhance domestic productivity growth and the 
insertion of local firms in world markets. Only by making progress on all three of these fronts can the region's economies hope to increase the growth rate, promote modernization and improve equity in the distribution of the benefits of these processes.

\section{The Development of Regulated Competition in Recently Privatized Industries}

As seen in chapter IV, several countries of the region opted for privatizating such sectors as telecommunications, energy and water sanitation. In most cases, however, such actions were undertaken without simultaneously increasing the role of competition, instead allowing monopoly conditions to prevail at least during the years immediately following privatization. It has now become clear that privatization with competition had different implications for social well-being than did privatization under monopoly conditions, even if in both cases the industry in question went through a major process of technological upgrading and modernization that brought it much closer to international productivity standards. If domestic consumers are to be adequately protected, competition has to be encouraged within these industries through the enforcement of new regulatory actions.

Recent European discussions on this topic show that loosely regulated privatizations repeatedly needed to be supplemented and adjusted in the search for effective competition (Armstrong, Cowan and Vickers, 1994, p. 355). Similarly, many recent privatizations in Latin America clearly demand new regulatory re-engineering efforts aimed at enforcing competition and consumer protection. Problems seen in the region include the failure to adequately provide the service (e.g., electricity cuts and water shortages) and compensation mechanisms when such failure occurs; the creation of artificial barriers to entry with a view to improving the future position of incumbent firms; the unilateral control of essential facilities and key natural resources along the production chain; uncertainty as to the mechanisms underlying tariff changes; the consolidation of dominant positions by global holding companies; the lack of legal protection for local minority shareholders; the absence within the regulatory framework of the principle of "reasonable return" (or "reasonable" profit rate), together with the lack of legal specification on the transfer of efficiency gains to local consumers; and the appeal to international jurisdiction, notwithstanding original agreements to submit grievances to local jurisdiction.

The gradual development of regulated competition should guarantee an adequate and sustainable service, on the one hand, and consumer protection, on the other, within an overall framework of respect for the investor. The regulatory framework must therefore contemplate the protection of the 
investors' rights, but not the exploitation of market failures, asymmetries of information and monopoly positions. Regulation should be accomplished by law, not by contract. It is important for Latin American countries to gradually develop their own regulatory skills, drawing on the accumulated legal and judiciary experience of more mature industrial countries.

\section{Competition Policy}

Given recent increases in business concentration across the Latin American production structure and the latest wave of mergers and acquisitions, competition policies have become paramount for consumer protection and the promotion of an efficient allocation of resources. The main purpose of competition policies is to curb monopolistic practices by preserving the free flow of information, discouraging the creation of artificial barriers to entry that could allow incumbent firms to manipulate prices, blockading the use of new technology, and so forth. Minority shareholders need to be protected from unfair trade practices, and collusion among competitors should be discouraged through new anti-trust legislation and judiciary practices (Scherer, 1980).

Recent trade liberalization and market deregulation efforts were based on the expectation that markets are contestable and that the potential entry of new rivals enforces market discipline among incumbent firms. This assumption proved to be strongly unrealistic, however, especially in cases in which patents and trademarks determine market structure and performance, as in the pharmaceuticals industry, for example. In such cases, domestic prices did not behave as originally expected, which resulted in significant losses in consumer well-being after the recent structural reforms. Competition rules need to be enforced in these industries in the near future (Katz, 1996). Competition authorities will have to examine cases of this sort thoroughly to determine whether higher prices stem from the introduction of innovations or from anticompetitive practices.

\section{Production and Innovation Policies}

Failure in factor markets - particularly in long-term capital markets and in the markets for technology and engineering services- is one of the key elements in the marked differences that industries, regions or even individual firms demonstrate in their ability to adapt to the new macroeconomic policy regime. Not every firm or industry has similar access to factor markets, and long-term opportunities and restrictions therefore vary considerably across economic activities, industries and regions of an economy and strongly condition the aggregate growth path. 
The discussion here covers to two main topics: (a) long-term financing for SMEs and (b) research and development expenditure and local innovation efforts, which affect the rate of innovation and productivity growth. Both are part of the explanation of why Latin American countries today exhibit a low productivity growth rate and find it difficult to improve their patterns of international competitiveness.

\section{(a) Policies Aimed at Strengthening the Long-term Performance of SMEs}

SMEs producing goods and services constitute a significant part of an economy's structure. They affect the efficiency and international competitiveness of sectors in which they participate as suppliers of large firms, as in the case of the vehicle industry or agribusiness. They often form the backbone of knowledge-intensive sectors such as biotechnology or software. Because SMEs generally have a substantial share of labour intensive industries producing wage goods, such as shoes, garments and furniture, they influence the aggregate rate of employment generation for the economy as a whole. Finally, they provide important services for natural resource-based industries, such as in mining, forestry and fisheries. SMEs thus play a number of roles in the economy: they generate employment, technology and exports, and their overall importance should not be underestimated.

SMEs have not done well in Latin America, however, after the implementation of the structural reforms. For reasons that have to do with imperfect access to information and imperfect functioning of factor markets, many SMEs have faced great difficulties in adapting to the new marketoriented macroeconomic policy regime. A large number have been forced to exit the market as a result of increasing competition from imported intermediate inputs, which has caused a great degree of disarray in many production chains.

Policy actions should be undertaken in several different directions to help SMEs attain a better long-term transition to a more open and deregulated macroeconomic policy regime. These include strengthening their strategic capabilities, especially in relation to the search for new markets and business areas; supporting the diffusion of new computer-based managerial knowhow that enable them to participate in real-time production organization arrangements; facilitating the diffusion of knowledge and understanding of quality control, product design engineering and just-in-time production planning and organization; and promoting the establishment of new knowledge-intensive firms.

SMEs need to enlarge their business perspective both locally and internationally. That requires them to undertake activities that are not traditional for small firms, such as acquiring information on new markets, choosing marketing methods, organizing distribution logistics, identifying representatives 
and distributors overseas, investing in the development of product trademarks and image, and providing post-sales services. Given the small size of many of these firms and the complexity of some of these tasks, collective development is an option that should not be underrated. Public policies should support the proper development of these critical inputs in conjunction with chambers of commerce, sectoral business associations and so forth.

With the opening of the economy to foreign competition, "going global" has ceased to be a matter of internal company decision-making. In the current context of open competitiveness, SMEs need to develop quality standards, technical norms and price competitiveness not only to compete in international markets, but also to face foreign competition in their own domestic market. Support for competitiveness thus demands the adoption of international quality standards -namely, ISO 9000 and 14000- and the development of much higher in-house capabilities in product design engineering and in production planning and organization.

With regard to exports, new entry should be encouraged by disseminating information of international trade fairs, trade regulations in would-be importing countries, competitive conditions that need to be met, and so forth. Special fiscal support could be given for firms entering export markets for the first time. For those already accustomed to export activities, support might come in the form of assistance for opening up new markets or establishing strategic alliances with large international distributors, for example.

Financing long-term capital investment has always been difficult for SMEs. There is now consensus that a purely legal approach is insufficient for developing long-term capital markets. While many countries in the world are undertaking increasingly complex activities to promote small firms, easing their access to credit seems to be one of the more difficult tasks. In the 1960s and 1970s the basic financing mechanism was credit with subsidized interest rates, granted by public development institutions (development banks). Private commercial banks scarcely participated on this front, concentrating instead on discounting commercial short-term debt, mostly related to the financing of working capital.

As part of recent changes in the macroeconomic policy regime, subsidies through low interest rates have practically been eliminated. The prevailing style of operation now involves more complex institutional arrangements, with State agencies and development banks acting as second-tier credit wholesalers and with private commercial banks directly linked to the firms and involved in their risk evaluation. Resorting to market principles in the management of support policies for SMEs seems to be a step in the right direction. The resources channelled to such activities are relatively minute so far, however, given the extent of the reconstruction of production and technological capabilities that is needed in this area. SMEs constitute a central pillar of social organization, and their long-term survival cannot be left to the casual determination of free market forces. 
Three basic principles should govern the functioning of institutional arrangements in this respect: no redundancy, targeting and additionality (Held, 1999). According to the no redundancy principle, credit lines or rediscounts provided by development banks should differ from those available in the market. Targeting means ensuring that the funds go to firms with characteristics identified as consistent with development policies, such as size, sector of economic activity, potential for employment generation or export capabilities. Notice that neutrality is not the issue here. In the transition to the new age of information technology, for example the whole field of software, computer-based technologies, logistics and the Internet has become a subject of great interest for many governments around the world and has thus received preferential policy support. The policy agenda for promoting SMEs should include aggressive action on this front. Finally, additionality means verifying that funds channelled through development banks really represent an increase in the total funds devoted to small firms, as opposed to resources that those firms would have secured anyway through credit from commercial banks.

Access to financial support should depend entirely on the private banks' assessment of the creditworthiness of the individual firms. For this purpose, banking institutions have to incorporate both a new attitude and new riskassessment technologies. They have to redefine their role as part of the country's development strategy and not just as profit-making institutions in the old, conventional style. Obviously, they need to be profitable, but their role as social institutions should be taken into account.

\section{(b) Policies Related to Innovation and the Generation and Diffusion of Technology}

As demonstrated in previous chapters, the region's patterns of production specialization and trade have undergone a major transformation in the course of the last two decades. This transformation was accompanied by a simultaneous weakening of the so-called national innovation system, that is, the set of institutions and interactions associated with the generation, adaptation and diffusion of technological knowledge and the development of domestic technological capabilities. The production structure has come to depend increasingly on access to foreign sources of new technology. Many of the learning mechanisms developed during the ISI period, as well as numerous domestic technological capabilities, have been seriously affected by the recent structural reforms, and action is urgently needed on this front if countries are to base their future expansion on local sources of growth.

The reconstruction of domestic technological capabilities has to take place within the context of the new regional patterns of production specialization. R\&D and innovation efforts should therefore aim to introduce more knowledge content into natural resource-processing activities, increasing their value 
added and domestic engineering content. This is entirely consistent with the pattern of comparative advantages of the region's economies. The development of synergies between local suppliers of capital goods for the natural resource-based industries and firms providing services such as transport, energy, telecommunications, refrigeration and storage, packaging and environmental protection seems to be a priority under present conditions. Biotechnologies, genetics applied to forestry and fisheries, software and logistics all belong within this category of knowledge-generation activities related to the natural resource-based sectors which should be strongly encouraged in the years ahead.

Most Latin American firms specializing in natural resource-based industries have fairly recently constructed highly capital intensive, state-ofthe-art plants, but they have specialized in commodities and have invested next to nothing in technological efforts to increase value added and domestic engineering content. The region's research infrastructure is clearly fragile with regard to supporting natural resource-based industries with a high domestic knowledge content. Countries such as Sweden and Finland have successfully developed the knowledge base with which to sustain and enrich the longterm exploitation of their rich endowments of natural resources. This is what Latin American countries have yet to accomplish.

Local spending on R\&D activities and the diffusion of technology should be increased significantly to converge with international practices. Firms should be encouraged to enter the field of knowledge generation and adaptation not only through conventional fiscal incentives but also via nonconventional mechanisms such as the establishment of technology parks and the promotion of alliances and partnerships with universities, foreign firms and so forth. The region needs to foster the creation of technology-based firms and the development of activities that are intensive in the use of science and technology, such as software or biotechnology, as these are crucial for the incorporation of higher value added to natural resources. The public sector should take responsibility for the more scientific areas of research -such as molecular biology, immunology, animal and plant genetics and mineralogyleaving to the private sector the development of new commercial technologies. Firms will scarcely be motivated to use their own resources to generate basic knowledge useful for these sectors, but they will probably take part in cooperative, pre-competitive work to capture the externalities of public efforts on this front. Allowing national universities to profit from patenting activities might be advisable in this connection.

At the same time, the region needs to modernize the public research infrastructure required for scientific and technological work in these areas. This should happen in conjunction with an improvement in the quality of innovation, stimulating the interaction among firms, suppliers and clients, universities, public and private research institutes and financial institutions. 
Every country in the region should promote such interactions at the highest political level, much as the Clinton Administration promoted the diffusion of Internet and the transition of the United States to a knowledge-based economy.

The successful development of natural resource-based industries depends on their upstream and downstream integration and the development of synergies with related services, such as shipping, transport, energy and telecommunications, which are crucial for the enhancement of international competitiveness in all of these fields. The country-specific nature of natural resources imposes the need to develop domestic sources of knowledge and engineering capabilities, instead of relying exclusively on internationally generated know-how. The fact that large multinational corporations now operate in many of these fields raises important questions on how to cover their idiosyncratic R\&D needs and how to address the issue of cooperative work involving the national innovative system and these global firms. Issues involving intellectual property rights and externalities must be treated carefully on a case-by-case basis.

In the process of expanding and improving domestic efforts related to innovation and knowledge generation, authorities must carefully examine the roles of public agencies, firms, universities and financial institutions. In particular, the private sector should be induced to significantly increase its commitment to knowledge-generation activities. While there are probably good reasons for firms' low commitment to $R \& D$ activities, it is precisely on this front that the pattern of public-private interaction needs to be adjusted in the future in order to establish a new, more knowledge-intensive path of longterm growth. The State has to adopt a proactive role in this respect, inducing, coordinating and promoting cooperative programmes in different fields, as well as financing the more basic scientific component of these activities. Public research agencies, universities and non-profit organizations must increasingly target their research efforts on those projects that generate externalities, allocating public funds according to quality and relevance.

Attaining these objectives demands that efforts be situated within an overall policy of competitiveness, and not merely isolated exercises as they have been in the past. Public policy in this field should comprise a reasonable mix of horizontal signals and selectivity. It is a matter of exploiting synergies and complementarities in specific fields in which national comparative advantages are most obvious, such that the issue of selectivity becomes almost irrelevant. A certain degree of selectivity is necessary, of course, for creating long-term, dynamic, comparative advantages in sectors that are close to and that complement the current pattern of production specialization. The trend towards integrating manufacturing production and post-sales services offers a broad range of possibilities for enriching the mix of goods offered on world markets, moving from commodities to specialty products that embody a higher domestic value added. 
With regard to linking horizontal, industry-specific and regional policies on innovation and technological diffusion, it seems reasonable to create a national agency for competitiveness and innovation whose central purpose would be to implement a national policy in this respect. This agency should have three main functions: (a) coordinating horizontal, industry-specific and regional science and technology policies and developing the institutional framework for cooperation among SMEs, large domestic and foreign firms, public R\&D institutes, universities and financial institutions; (b) relating these policies and institutions to the country's present pattern of international competitiveness, especially in light of the future implications of the Uruguay Round commitments; and (c) negotiating with large domestic conglomerates and subsidiaries of multinational firms to establish domestic R\&D programmes capable of enhancing systemic competition. Issues that need to be explored with large national and foreign firms include, for example, the export of goods and services with higher domestic value added and the development of cooperative R\&D programmes in conjunction with SMEs and intermediate part suppliers.

If Latin American countries want to accelerate their rate of productivity growth and attain a more equitable distribution of the benefits of the transition to a more open, deregulated macroeconomic policy regime, they must move towards a pragmatic stage of reforming the reforms. New regulatory and competition policies, together with new actions related to strengthening domestic innovation and technological capabilities, are urgently needed if the benefits of the recent structural reforms are to be sustained and more equitably distributed in the future. 



\section{BIBLIOGRAPHY}

Alonso, J., J. Carrillo and O. Contreras (1999), “Trayectorias tecnológicas en empresas maquiladoras asiáticas y americanas en México", Santiago, Chile, Division of Production, Productivity and Management, Economic Commission for Latin America and the Caribbean (ECLAC), unpublished.

Armstrong, Mark, Simon Cowan and John Vickers (1994), “Regulatory Reform: Economic Analysis and British Experience", MIT Press Series on the Regulation of Economic Activity, No. 20, Cambridge, Massachusetts, The MIT Press.

Azpiazu, D. and Eduardo Basualdo (1997), “Internationalization Reconsidered: The Case of Siderar", Sloan Working Paper, No. 3938.

Bain, Joe S. (1966), Industrial Organization, Cambridge, Cambridge University Press.

(1956), Barriers to New Competition: their Character and Consequences in Manufacturing Industries, Cambridge, Massachusetts, Harvard University Press.

Barbosa, Gustavo (1999), “Crecimiento, empleo y equidad en América Latina: cambio tecnológico en el sector de energía y telecomunicaciones en Costa Rica", San José, Costa Rica, Economic Science Research Institute (IICE), University of Costa Rica, unpublished.

Benavente, J. M. and others (1997), "New problems and opportunities for industrial development in Latin America", Oxford Development Studies, vol. 25, No. 3.

Bercovich, Néstor (2000), “Evolución y situación actual del complejo forestal en Argentina", working paper. ECLAC/IDRC project "Industrial 
restructuring, innovation and international competitiveness in Latin America (Phase II)".

Bercovich, Néstor and Jorge Katz (eds.) (1997), Reestructuración industrial y apertura económica: La industria de celulosa y papel de Argentina, Brasil y Chile en los años 90, Buenos Aires, Alianza Editorial.

Boyer, Robert (1991), "New Directions in Management Practices and Work Organizations. General Principles and National Trajectories", Couverture Orange CEPREMAP, No. 9130, prepared for the OECD conference on "Technological Change as a Social Process: Society, Equity and Individuals", Helsinki.

(1986), La théorie de la régulation: une analyse critique, Paris, La Découverte.

Buitelaar, Rudolf, Ramón Padilla and Ruth Urrutia (1999), Centroamérica, México y República Dominicana: maquila y transformación productiva, Cuadernos de la CEPAL series, No. 85 (LC/G.2047-P), Santiago, Chile, Economic Commission for Latin America and the Caribbean (ECLAC). United Nations publication, Sales No. S.99.II.G.20.

Cáceres, Jaime, Kattia Cárdenas and Jorge Katz (2000), “Instituciones y tecnología en el desarrollo evolutivo de la industria minera chilena", Reformas económicas series, No. 53 (LC/L.1349), Santiago, Chile, Economic Commission for Latin America and the Caribbean (ECLAC).

Carlsson, Bo (1995), Technological Systems and Economic Performance: The Case of Factory Automation, London, Kluwer Academic Publishers.

Celani, Marcelo (1998) "Determinantes de la inversión en telecomunicaciones en Argentina", Reformas económicas series, No. 9 (LC/L.1157), Santiago, Chile, Economic Commission for Latin America and the Caribbean (ECLAC).

Chandler, Aldred (1990), Scale and Scope: The Dynamics of Industrial Capitalism, Cambridge, Massachusetts, The Belknap Press of Harvard University Press.

Chica, Ricardo (1999), “Crecimiento, cambio tecnológico y comportamiento del Sistema Nacional de Innovación", Bogotá, Colombian Fund for Scientific Research and Special Projects (COLCIENCIAS).

Cimoli, Mario (ed.) (2000), Developing innovation systems: Mexico in a global context, science, technology and international political economy, London, Continuum.

David, Paul (1994), "Why are institutions the "carriers of history"? Path dependence and the evolution of conventions, organizations and institutions", Structural Change and Economic Dynamics, vol. 5, No. 2.

De Wolf, M.M. (1998), “La Administración Nacional de Telecomunicaciones de Uruguay. Fracaso de una privatización y éxito de una empresa estatal", La privatización de las telecomunicaciones en América Latina. Empresas y Sindicatos ante los desafíos de la reestructuración, Jorge Walter (ed.), Buenos Aires, Editorial Universitaria. 
Dosi, Giovanni (1982), "Technical paradigms and technological trajectories. Suggested interpretations of the determinants and directions of technical change", Research Policy, vol. 11, No. 3.

Dosi, Giovanni (ed.) (1988), Technical Change and Economic Theory, London, Pinter Publishers.

Dutrenit, Gabriela (1998), “From Knowledge Accumulation to Strategic Capabilities: Knowledge Management in a Mexican Glass Firm", doctoral thesis, Science Policy Research Unit, University of Sussex, September.

ECLAC (Economic Commission for Latin America and the Caribbean) (2000), Equity, development and citizenship (LC/G.2071(SES.28/3)), Santiago, Chile.

Fanelli, José María and Roberto Frenkel (1996), “Estabilidad y estructura: interacciones en el crecimiento económico", Estabilización macroeconómica, reforma estructural y comportamiento industrial; estructura y funcionamiento del sector manufacturero latinoamericano en los años 90, Jorge Katz (ed.), Buenos Aires, Alianza Editorial.

Ferraz, Joâo Carlos, D.S. Kupfer and Lía Hauguenauer (1995), Made in Brazil: desafíos competitivos para la industria, Rio de Janeiro, Campus.

Ffrench-Davis, Ricardo (1999), Reforming the Reforms in Latin America: Macroeconomics, Trade, Finance, London, Macmillan.

Ffrench-Davis, Ricardo and Stephany Griffith-Jones (eds.) (1995), Coping with Capital Surges: The Return of Finance to Latin America, Boulder, CO, Lynne Rienner Publishers.

Freeman, Chris (1995), “The 'National System of Innovation' in historical perspective", Cambridge Journal of Economics, vol. 19, No. 1.

(1994), "The economics of technical change", Cambridge Journal of Economics, vol. 18, No. 5.

(1974), The Economics of Industrial Innovation, first edition, Harmondsworth, Penguin; second edition, London, Frances Pinter, 1982.

GACTEC (Gabinete Científico Tecnológico) (1998), Proyecto de Plan Nacional Plurianual de Ciencia y Tecnología 1999-2001, Buenos Aires, Poder Ejecutivo Nacional, December.

Granovetter, Mark (1985), "Economic action and social structure. The problem of embeddedness", American Journal of Sociology, vol. 91, No. 3.

Harberger, Arnold (1998), "A vision of the growth process", American Economic Review, vol. 88, No. 1.

Held, Günther (1999), "Politicas de crédito para empresas de menor tamaño con bancos de segundo piso: experiencias recientes en Chile, Colombia y Costa Rica", Financiamiento del desarrollo series, No. 84 (LC/L.1259P), Santiago, Chile, Economic Commission for Latin America and the Caribbean (ECLAC).

Hicks, J.R. (1932), The Theory of Wages, London, Macmillan. 
Kassai, László (2000), “Cuero, calzado y afines en Chile. ¿Una industria en desaparición o en búsqueda de un nuevo destino?, Desarrollo Productivo series, No. 97, Santiago, Chile, Economic Commission for Latin America and the Caribbean (ECLAC).

Katz, Jorge (1997), "New problems and opportunities for industrial development in Latin America", Oxford Development Studies, vol. 25, No. 3.

(1987), Technology Generation in Latin American Manufacturing Industries: Theory and Case-Studies Concerning its Nature, Magnitude and Consequences, London, Macmillan.

(1986), Desarrollo y crisis de la capacidad tecnológica latinoamericana: el caso de la industria metalmecánica, Buenos Aires, Economic Commission for Latin America and the Caribbean (ECLAC). (1982), "Technology and economic development: an overview of research findings", Trade, Stability, Technology and Equity in Latin America, Moshé Syriquin and Simón Teitel (eds.), New York, Academic Press. (1974), Importación de tecnología, aprendizaje local e industrialización dependiente, Mexico City, Fondo de Cultura Económica.

Katz, Jorge (ed.) (1996), Estabilización macroeconómica, reforma estructural y comportamiento industrial; estructura y funcionamiento del sector manufacturero latinoamericano en los años 90, Buenos Aires, Alianza Editorial.

Katz, Jorge and Bernardo Kosacoff (1989), El proceso de industrialización en la Argentina: evolución, retroceso y prospectiva, Buenos Aires, Centro Editor de América Latina.

Katz, Jorge and Héctor Vera (1997), "Historia evolutiva de una planta metalmecánica chilena: relaciones micro/macroeconómicas con la conducta innovativa", Desarrollo productivo series, No. 30 (LC/ G.1887), Santiago, Chile, Economic Commission for Latin America and the Caribbean (ECLAC).

Kornai, Janos (1986), "The soft budget constraint", Kyklos, vol. 39.

Krugman, Paul (1993), "A counter-counter revolution to the theory of economic development", Proceedings of the World Bank Annual Conference on Development Economics, 1992, Washington, D.C., World Bank.

Laffont, Jean-Jacques and Jean Tirole (1998), "Competition in Telecommunications", conference of Munich University, March, unpublished.

Lipsey, Richard and K. Carlaw (1998), "Assessing Innovation Policies: Taking Schumpeter Seriously on Technology Policy", Industry Canada Working Paper, No. 25, Ottawa.

Lloyd, J. (1999), “Who lost Russia?" New York Times Magazine, 15 August.

Malerba, Franco (1997), "Sectoral systems of innovation and production", Working Paper, Bocconi University, Milan. 
Miranda, J.C. (1996), "Reestructuración industrial en un contexto de inestabilidad macroeconómica. El caso de Brasil", Estabilización macroeconómica, reforma estructural y comportamiento industrial; estructura y funcionamiento del sector manufacturero latinoamericano en los años 90, Jorge Katz (ed.), Buenos Aires, Alianza Editorial.

Mizala, Alejandra (1992), "Las reformas económicas de los años setenta y la industria manufacturera chilena", Colección estudios CIEPLAN, No. 35, Santiago, Chile.

Moguillansky, Graciela (1999), La inversión en Chile: ¿el fin de un ciclo de expansión?, Santiago, Chile, Economic Commission for Latin America and the Caribbean (ECLAC)/Fondo de Cultura Económica.

Moguillansky, Graciela and Ricardo Bielchowsky (2000), Inversión y reformas económicas en América Latina, Santiago, Chile, Economic Commission for Latin America and the Caribbean (ECLAC) and Fondo de Cultura Económica. (English translation: Investment and Economic Reforms in Latin America, Santiago, Chile, ECLAC, 2001).

Nelson, Richard (1997), "How new is new growth theory?", Challenge, October. (1962), "The link between science and invention: the case of the transistor", The Rate and Direction of Inventive Activity: Economic and Social Factors, Princeton, New Jersey, National Bureau of Economic Research (NBER), Princeton University Press. (1959), "The simple economics of basic scientific research", Journal of Political Economy, vol. 67, No. 3.

North, Douglas (1996), "Economic performance through time: the limits to knowledge", St Louis, Washington University, August, unpublished.

Obschatko, Edith (1997), "Articulación productiva a partir de los recursos naturales: el caso del complejo oleaginoso argentino", Working Paper, No. 74 (LC/BUE/L.157), Buenos Aires, Economic Commission for Latin America and the Caribbean (ECLAC). (1996), "Industrialización basada en recursos naturales: El caso del complejo oleaginoso argentino", Buenos Aires, Economic Commission for Latin America and the Caribbean (ECLAC), unpublished.

Olson, Mary (1991), "Political Influence and the Development of U.S. Regulatory Policy: The 1984 Drug Legislation", Discussion Paper Series CEPR, No. 249, Stanford University.

Pavitt, Keith (1984), "Sectoral patterns of technology change: towards a taxonomy and a theory", Research Policy, vol. 13, No. 6.

Penrose, Edith (1951), The Economics of the International Patent System, Baltimore, The Johns Hopkins University Press.

Peres, Wilson (ed.) (1999), Grandes empresas y grupos industriales latinoamericanos: expansión y desafíos en la era de la apertura y la globalización, Mexico City, Siglo Veintiuno Editores. 
Reinhardt, Nola and Wilson Peres (eds.) (2000), “Latin America's new economic model: micro responses and economic restructuring", World Development, vol. 28, No. 9.

Salter, W.E.G. (1960), Productivity and Technical Change, Cambridge, United Kingdom, Cambridge University Press.

Saxonian, Anne (1995), Regional Advantage, Culture and competition in Silicon Valley and Route 128, Cambridge, Massachusetts, Harvard University Press.

Scherer, Frederic (1980), Industrial Market Structure and Economic Performance, second edition, Chicago, Rand Mc Nally.

Schmookler, Jacob (1966), Invention and Economic Growth, Cambridge, Massachusetts, Harvard University Press.

Simon, Herbert A. (1959), "Theories of decision-making in economics and behavioural science", American Economic Review, vol. 49, No. 3. (1955), "A behavioral model of rational choice", Quarterly Journal of Economics, vol. 69, No. 1.

Solow, Robert (1988), "Growth theory and after", American Economic Review, vol. 78 , No. 3.

Stallings, Barbara and Wilson Peres (2000), Growth, Employment and Equity: the Impact of the Economic Reforms in Latin America and the Caribbean, Washington, D.C., The Brookings Institution/Economic Commission for Latin America and the Caribbean (ECLAC).

Stiglitz, Joseph E. (1998a), "Redefining the role of the State: what should it do, how should it do it, and how should the decisions be made?", Washington, D.C., World Bank, March, unpublished.

(1998b) "Más instrumentos y metas más amplias para el desarrollo: hacia el consenso post-Washington", Desarrollo Económico, vol. 38, No. 151.

(1993), “Comments", al trabajo de Paul Krugman, "A counter-counter revolution to the theory of economic development", Proceedings of the World Bank Annual Conference on Development Economics, 1992, Washington, D.C., World Bank.

Tavares de Araujo Jr., José and Luis Tineo (1999), “Competition policy and regional trade agreements", Trade Rules in the Making, Challenges in Regional and Multilateral Negotiations, Miguel Rodríguez Mendoza, Patrick Low and Barbara Kotschwar (eds.), Washington, D.C., Brookings Institution Press.

Terleckij Nestor (1959), "Sources of productivity growth in the US manufacturing sector", doctoral thesis, New York, Columbia University.

Walter, Jorge (2000), "La privatización de las telecomunicaciones en Latinoamérica. Estudio comparativo: el caso Argentino", Buenos Aires, Working Paper, No. 9, Department of Business Administration, San Andrés University. 
Walter, Jorge and Eduardo Gore (1996), “Una vidriera espejada. Modernización tecnológica sistémica y nuevas tecnologías educativas en una empresa telefónica privatizada de la Argentina", document prepared for the international colloquium "Aprendizaje tecnológico, innovación y política industrial: experiencia nacionales e internacionales", Mexico City, 25-27 September.

Walter, Jorge and Cecilia Senén González (eds.) (1998), La privatización de las telecomunicaciones en América Latina: empresas y sindicatos ante los desafíos de la reestructuración, Buenos Aires, Editorial Universitaria de Buenos Aires (EUDEBA).

Weller, Jürgen (2000), Reformas económicas, crecimiento y empleo: los mercados de trabajo en América Latina y el Caribe, Santiago, Chile, Economic Commission for Latin America and the Caribbean (ECLAC) and Fondo de Cultura Económica. (English translation: Economic Reforms, Growth and Employment: Labour Markets in Latin America and the Caribbean, Santiago, Chile, ECLAC, 2001).

Williamson, John (ed.) (1990), Latin American Adjustment: How Much Has Happened?, Washington, D.C., Institute for International Economics (IIE).

Williamson, Oliver (1985), The Economic Institutions of Capitalism, New York, The Free Press. (1975), Markets and Hierarchies: Analysis and Anti-Trust Implications, New York, The Free Press. 
